\title{
Nutrients in Waters of the Santee River Basin and Coastal Drainages, North and South Carolina, 1973-93
}

By Terry L. Maluk, Eric J. Reuber, and W. Brian Hughes

\section{U.S. GEOLOGICAL SURVEY}

Water-Resources Investigations Report 97-4172

Prepared as part of the

NATIONAL WATER-QUALITY ASSESSMENT PROGRAM

Columbia, South Carolina 1998 


\title{
U.S. DEPARTMENT OF THE INTERIOR BRUCE BABBITT, Secretary
}

\author{
U.S. GEOLOGICAL SURVEY
}

Thomas J. Casadevall, Acting Director

The use of firm, trade, and brand names in this report is for identification purposes only and does not constitute endorsement by the U.S. Government.

For additional information write to:

District Chief

U.S. Geological Survey

Stephenson Center-Suite 129

720 Gracern Road

Columbia, South Carolina 29210-7651
Copies of this report can be purchased from:

U.S. Geological Survey

Branch of Information Services

Box 25286

Denver, Colorado 80225-0286 


\section{FOREWORD}

The mission of the U.S. Geological Survey (USGS) is to assess the quantity and quality of the earth resources of the Nation and to provide information that will assist resource managers and policymakers at Federal, State, and local levels in making sound decisions. Assessment of water-quality conditions and trends is an important part of this overall mission.

One of the greatest challenges faced by waterresources scientists is acquiring reliable information that will guide the use and protection of the Nation's water resources. That challenge is being addressed by Federal, State, interstate, and local water-resource agencies and by many academic institutions. These organizations are collecting water-quality data for a host of purposes that include: compliance with permits and water-supply standards; development of remediation plans for a specific contamination problem; operational decisions on industrial, wastewater, or watersupply facilities; and research on factors that affect water quality. An additional need for water-quality information is to provide a basis on which regional and national-level policy decisions can be based. Wise decisions must be based on sound information. As a society we need to know whether certain types of water-quality problems are isolated or ubiquitous, whether there are significant differences in conditions among regions, whether the conditions are changing over time, and why these conditions change from place to place and over time. The information can be used to help determine the efficacy of existing waterquality policies and to help analysts determine the need for and likely consequences of new policies.

To address these needs, the Congress appropriated funds in 1986 for the USGS to begin a pilot program in seven project areas to develop and refine the National Water-Quality Assessment (NAWQA) Program. In 1991, the USGS began full implementation of the program. The NAWQA Program builds upon an existing base of water-quality studies of the USGS, as well as those of other Federal, State, and local agencies. The objectives of the NAWQA Program are to:

-Describe current water-quality conditions for a large part of the Nation's freshwater streams, rivers, and aquifers.
-Describe how water quality is changing over time.

-Improve understanding of the primary natural and human factors that affect water-quality conditions.

This information will help support the development and evaluation of management, regulatory, and monitoring decisions by other Federal, State, and local agencies to protect, use, and enhance water resources.

The goals of the NAWQA Program are being achieved through ongoing and proposed investigations of 60 of the Nation's most important river basins and aquifer systems, which are referred to as study units. These study units are distributed throughout the Nation and cover a diversity of hydrogeologic settings. More than two-thirds of the Nation's freshwater use occurs within the 60 study units and more than two-thirds of the people served by public water-supply systems live within their boundaries.

National synthesis of data analysis, based on aggregation of comparable information obtained from the study units, is a major component of the program. This effort focuses on selected water-quality topics using nationally consistent information. Comparative studies will explain differences and similarities in observed water-quality conditions among study areas and will identify changes and trends and their causes. The first topics addressed by the national synthesis are pesticides, nutrients, volatile organic compounds, and aquatic biology. Discussions on these and other waterquality topics will be published in periodic summaries of the quality of the Nation's ground and surface water as the information becomes available.

This report is an element of the comprehensive body of information developed as part of the NAWQA Program. The program depends heavily on the advice, cooperation, and information from many Federal, State, interstate, Tribal, and local agencies and the public. The assistance and suggestions of all are greatly appreciated.
Robert M. Hirsch

Chief Hydrologist 


\section{CONTENTS}

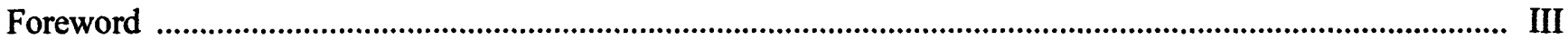

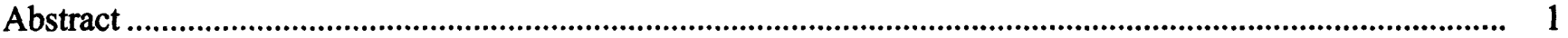

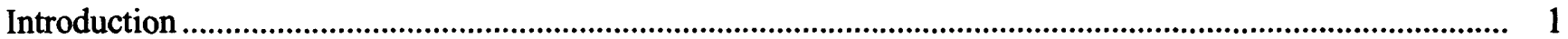

Purpose and Scope ......................................................................................................................................... 2

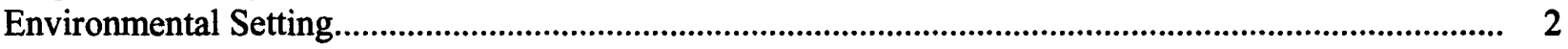

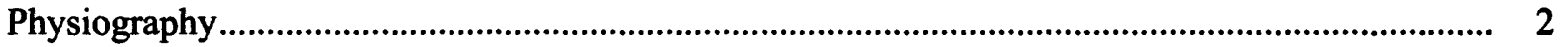

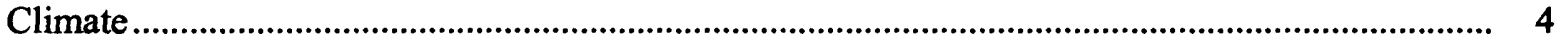

Surface-Water Hydrology .............................................................................................................. 4

Ground-Water Hydrology ............................................................................................................ 5

Land and Water Use ..................................................................................................................... 5

Acknowledgments................................................................................................................................... 5

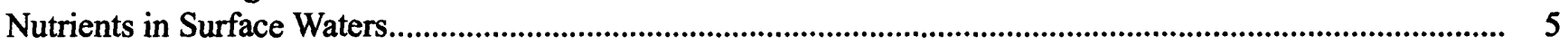

Water-Quality Criteria ............................................................................................................................... 6

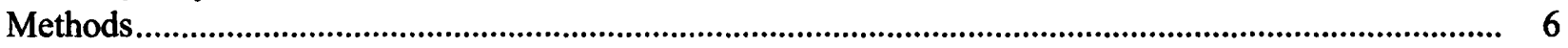

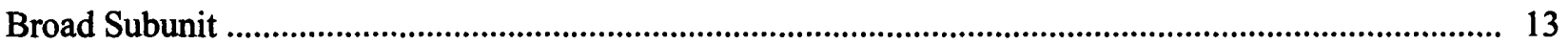

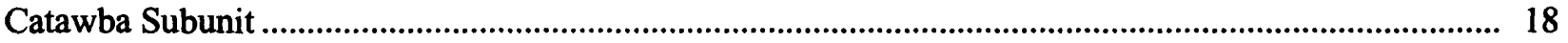

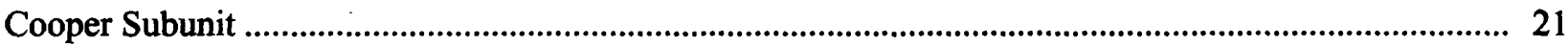

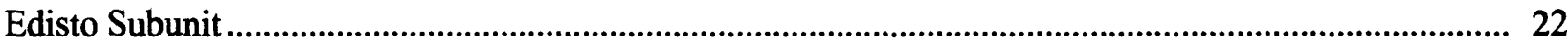

Seasonality of Nutrient Concentrations ............................................................................................. 28

Study Area Nutrient Loads ........................................................................................................................ 34

Nonpoint Sources.......................................................................................................................... 34

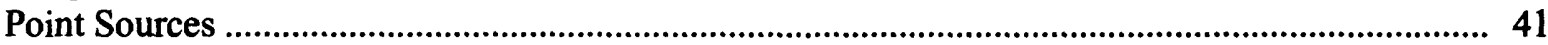

Nutrient Load Comparisons for Selected Stations ................................................................................. 42

Broad River and Tributaries................................................................................................ 42

Streamflows...................................................................................................................... 42

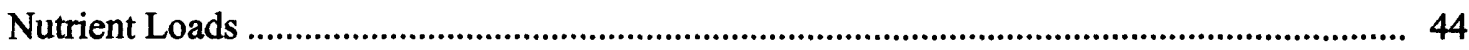

Contributions from Nonpoint Sources .............................................................................. 44

Saluda and Reedy Rivers .................................................................................................................... 44

Streamflows.................................................................................................................. 50

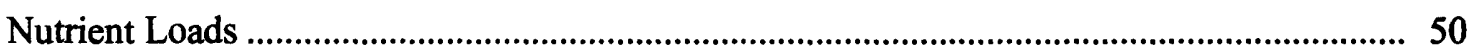

Contributions from Nonpoint Sources ................................................................................ 55

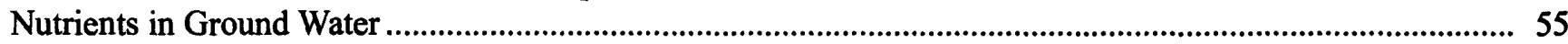

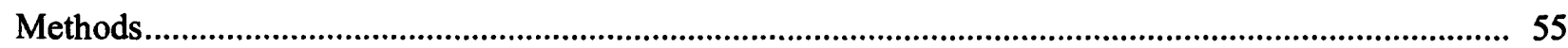

Ground-Water Nitrate Concentrations ..................................................................................... 58

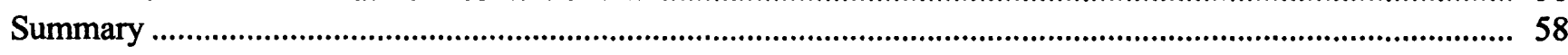

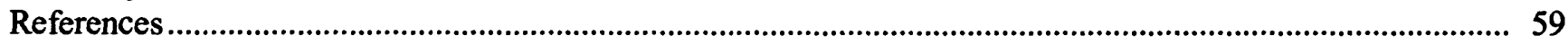


1-3. Maps showing:

1. Physiographic provinces of the SANT study area ….............................................................. 3

2. Surface-water-quality stations used for nutrient assessment .............................................. 7

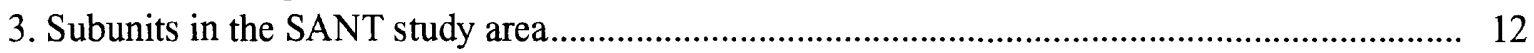

4-23. Graphs showing:

4. Ammonia nitrogen concentrations in the Broad subunit, SANT study area, 1973-93 ........... 14

5. Nitrite-plus-nitrate nitrogen concentrations in the Broad subunit, SANT study area, 1973-93

6. Total Kjeldahl nitrogen concentrations in the Broad subunit, SANT study area, 1973-93 _...... 15

7. Total phosphorus concentrations in the Broad subunit, SANT study area, 1973-93 ............... 15

8. Ammonia nitrogen concentrations in the Catawba subunit, SANT study area, 1973-93 .......... 19

9. Nitrite-plus-nitrate nitrogen concentrations in the Catawba subunit, SANT study area, $1973-93$............................................................................................... 19

10. Total Kjeldahl nitrogen concentrations in the Catawba subunit, SANT study area, 1973-93 .... 20

11. Total phosphorus concentrations in the Catawba subunit, SANT study area, 1973-93............ 20

12. Ammonia nitrogen concentrations in the Cooper subunit, SANT study area, 1973-93 ............ 23

13. Nitrite-plus-nitrate nitrogen concentrations in the Cooper subunit, SANT study

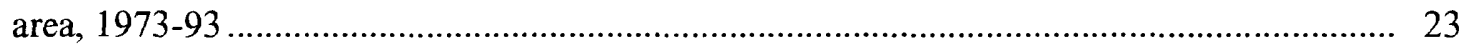

14. Total Kjeldahl nitrogen concentrations in the Cooper subunit, SANT study area, 1973-93 ...... 24

15. Total phosphorus concentrations in the Cooper subunit, SANT study area, 1973-93............... 24

16. Ammonia nitrogen concentrations in the Edisto subunit, SANT study area, 1973-93 ............. 26

17. Nitrite-plus-nitrate nitrogen concentrations in the Edisto subunit, SANT study

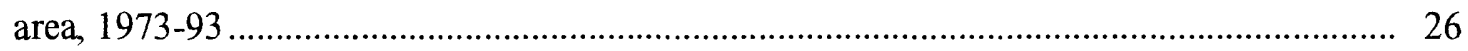

18. Total Kjeldahl nitrogen concentrations in the Edisto subunit, SANT study area, 1973-93 ....... 27

19. Total phosphorus concentrations in the Edisto subunit, SANT study area, 1973-93 ............... 27

20. Monthly nitrite-plus-nitrate nitrogen concentrations at the Salkehatchie River at U.S. Route 278, SANT study area, 1973-93 ................................................................. 29

21. Monthly nitrite-plus-nitrate nitrogen concentrations at the Cooper River at S.C.

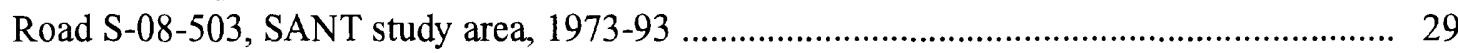

22. Monthly nitrite-plus-nitrate nitrogen concentrations at Gills Creek, Forest Acres, SANT study area, 1973-93

23. Monthly total phosphorus concentrations at the South Fork Catawba River, SANT

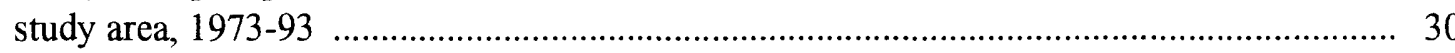

24. Map showing nitrogen application rates from fertilizer by county, SANT study area, 1987 ........... 35

25. Map showing phosphorus application rates from fertilizer by county, SANT study area, 1987....... 36

26. Graph showing nonpoint-source nitrogen and phosphorus loads in the SANT study area ............... 41

27. Map showing selected stations for nutrient load calculations in the SANT study area ................... 43 
28-40. Graphs showing:

28. Median monthly and annual ammonia nitrogen loads in the Broad, Tyger, and Enoree

Rivers, SANT study area, 1973-93

29. Median monthly and annual nitrite-plus-nitrate nitrogen loads in the Broad, Tyger, and

Enoree Rivers, SANT study area, 1973-93.

30. Median monthly and annual total Kjeldahl nitrogen loads in the Broad, Tyger, and Enoree

Rivers, SANT study area, 1974-93

31. Median monthly and annual total phosphorus loads in the Broad, Tyger, and Enoree

Rivers, SANT study area, 1973-93

32. Nonpoint-source nitrogen loads in the Broad River drainage basin, SANT study area

33. Nonpoint-source phosphorus loads in the Broad River drainage basin, SANT study area

34. Median monthly and annual ammonia nitrogen loads in the Saluda and Reedy Rivers,

SANT study area, 1974-93

35. Median monthly and annual nitrite-plus-nitrate nitrogen loads in the Saluda and Reedy

Rivers, SANT study area, 1973-93

36. Median monthly and annual total Kjeldahl nitrogen loads in the Saluda and Reedy Rivers,

SANT study area, 1974-93

37. Median monthly and annual total phosphorus loads in the Saluda and Reedy Rivers, SANT study area, 1974-93.....

38. Nonpoint-source nitrogen loads in the Saluda River drainage basin, SANT study area

39. Nonpoint-source phosphorus loads in the Saluda River drainage basin, SANT study area 56

40. Ground-water nitrate concentrations in the SANT study area, 1946-85.

\section{TABLES}

1. Streamflows of major rivers draining the SANT study area.

2. Surface-water-quality stations used for nutrient assessment, SANT study area, 1973-93................... 8

3. Temporal nutrient trends in the Broad subunit, SANT study area, 1973-93 ..................................... 16

4. Temporal nutrient trends in the Catawba subunit, SANT study area, 1973-93 .................................. 21

5. Temporal nutrient trends in the Cooper subunit, SANT study area, 1973-93 .................................... 25

6. Temporal nutrient trends in the Edisto subunit, SANT study area, 1973-93 ..................................... 28

7. Seasonal nutrient trends in the SANT study area, 1973-93 ........................................................... 31

8. Annual average atmospheric deposition of ammonia and nitrate nitrogen in the SANT study area, 1982-1993

9. Fertilizer and manure nitrogen application rates in the SANT study area by county, 1987 (fertilizer), 1992 (manure)

10. Fertilizer and manure phosphorus application rates in the SANT study area by county, 1987 (fertilizer), 1992 (manure)

11. Streamflows at selected U.S. Geological Survey gaging stations in the Broad River drainage basin.

12. Streamflows at selected U.S. Geological Survey gaging stations in the Saluda River drainage basin 
CONVERSION FACTORS, VERTICAL DATUM, AND ACRONYMS

\begin{tabular}{|c|c|c|}
\hline Multiply & By & To obtain \\
\hline inch & 25.4 & millimeter \\
\hline foot (ft) & 0.3048 & meter \\
\hline acre & 43,560 & square foot \\
\hline acre-foot (acre-ft) & 1.233 & cubic meter \\
\hline pound (lb) & 0.4536 & kilogram \\
\hline square foot per day $\left(\mathrm{ft}^{2} / \mathrm{d}\right)$ & 0.0929 & square meter per day \\
\hline cubic foot per second $\left(\mathrm{ft}^{3} / \mathrm{s}\right)$ & 0.02832 & cubic meter per second \\
\hline mile (mi) & 1.609 & kilometer \\
\hline square mile $\left(\mathrm{mi}^{2}\right)$ & 2.590 & square kilometer \\
\hline gallon per $\min (\mathrm{gal} / \mathrm{min})$ & 3.785 & liter per minute \\
\hline million gallons per day (Mgal/d) & 3.785 & million liters per day \\
\hline million gallons per day (Mgal/d) & 0.0438 & cubic meter per second \\
\hline gallon per day per foot $[(\mathrm{gal} / \mathrm{d}) / \mathrm{ft}]$ & 12.41 & liter per day per meter \\
\hline ton per square mile (ton $/ \mathrm{mi}^{2}$ ) & 0.3503 & ton per square kilometer \\
\hline
\end{tabular}

Sea level: In this report, "sea level" refers to the National Geodetic Vertical Datum of 1929--a geodetic datum derived from a general adjustment of the first-order level nets of the United States and Canada, formerly called Sea Level datum of 1929.

The standard unit for hydraulic conductivity is cubic foot per day per square foot $\left[\left(\mathrm{ft}^{3} / \mathrm{d}\right) / \mathrm{ft}^{2}\right]$. This mathematical expression reduces to foot per day $(\mathrm{ft} / \mathrm{d})$.

Temperature in degrees Fahrenheit $\left({ }^{\circ} \mathrm{F}\right)$ can be converted to degrees Celcius: ${ }^{\circ} \mathrm{C}=5 / 9\left({ }^{\circ} \mathrm{F}-32\right)$.

\section{Abbreviated units used this report:}

$\begin{array}{ll}\mathrm{mg} / \mathrm{L} & \text { milligram per liter } \\ \mathrm{kton} / \mathrm{yr} & \text { kiloton per year } \\ \mathrm{ton} / \mathrm{yr} & \text { ton per year } \\ \mathrm{lb} / \mathrm{d} & \text { pound per day } \\ \mathrm{Bgal} / \mathrm{d} & \text { billion gallons per day } \\ \mathrm{in} / \mathrm{yr} & \text { inch per year }\end{array}$

\section{Acronyms and definitions used in this report:}

GIRAS

NADP/NTN

geographic information retrieval and analysis system

NASQAN

National Atmospheric Deposition Program/National Trends Network

NAWQA

National Stream-Quality Accounting Network

NCDEHNR

National Water Quality Assessment Program

NPDES

North Carolina Department of Environment, Health and Natural Resources

PCS

SANT

SCDHEC

National Pollutant Discharge Elimination System

Permit Compliance System

Santee River Basin and coastal drainages

South Carolina Department of Health and Environmental Control

STORET

Storage and Retrieval

USEPA

U.S. Environmental Protection Agency

USGS

U.S. Geological Survey

WATSTORE

Water Storage and Retrieval 


\title{
NUTRIENTS IN WATERS OF THE SANTEE RIVER BASIN AND COASTAL DRAINAGES, NORTH AND SOUTH CAROLINA, 1973-93
}

\author{
By Terry L. Maluk, Eric J. Reuber, and W. Brian Hughes
}

\section{ABSTRACT}

Nutrient data from 90 stations in the Santee River Basin and coastal drainages study area were assessed for 1973-93 as part of the U.S. Geological Survey National Water-Quality Assessment Program. Data sources include the U.S. Geological Survey National Stream-Quality Accounting Network and the U.S. Environmental Protection Agency Storage and Retrieval of U.S. Waterways Parametric Data databases. Specific nutrient species chosen for assessment were total ammonia nitrogen, nitrite-plus-nitrate nitrogen, total Kjeldahl nitrogen, and total phosphorus.

The study area was divided into four subunits: the Broad, Catawba, Cooper, and Edisto. Nutrient concentrations were generally higher in the Broad and Catawba subunits, where some stations were influenced by point-source discharges, than in the Cooper and Edisto subunits. Nitriteplus-nitrate nitrogen showed the greatest seasonal variation of the nutrients assessed.

Nonpoint-source nutrient contributions to the study area include atmospheric input and fertilizer and manure applications. Atmospheric ammonia nitrogen and nitrate nitrogen inputs were determined using data from four National Atmospheric Deposition Program/National Trends Network stations. Nonpoint-source loads of nitrogen were higher from atmospheric sources than from fertilizer or manure applications. Nonpoint-source loads of phosphorus were higher from fertilizer applications than from manure applications.
Nutrient loads being carried by streams were estimated at seven stations in the Santee River Basin and coastal drainages study area where concurrent flow and water-quality data were available for at least 13 years. Monthly and annual median loads were calculated for each of the seven stations for ammonia nitrogen, nitrite-plus-nitrate nitrogen, total Kjeldahl nitrogen, and total phosphorus, and spatial comparisons were made between loads along the rivers. Nonpoint-source contributions were also estimated for the drainage basins of the seven stations.

Ground-water nitrate data were compiled from three sources: the South Carolina Department of Health and Environmental Control ambient ground-water-quality network, Clemson University agriculturally influenced ground-water data, and the U.S. Geological Survey Water Storage and Retrieval system (WATSTORE). The compiled data showed that the mean nitrate concentration of the agriculturally influenced wells was higher than the ambient and WATSTORE well concentrations.

\section{INTRODUCTION}

The U.S. Geological Survey (USGS) is conducting an assessment of water quality in the Santee River Basin and coastal drainages (SANT) study area as part of the National Water-Quality Assessment (NAWQA) Program. The long-term goals of NAWQA are to describe the status of and trends in the quality of a large representative part of the Nation's surface- and ground- 
water resources and to identify major factors that affect the quality of these resources. A total of 59 hydrologic systems are to be studied that include parts of most major river basins and aquifer systems in the Nation. The assessment activities in the SANT study area began in 1994.

\section{Purpose and Scope}

This report presents a retrospective analysis of nutrient data from the SANT study area for 1973-93. Temporal and spatial occurrence of selected nutrients in surface water and ground water are presented, as well as nutrient loads for several basins. Specific surface-water nutrients assessed in this report are total ammonia nitrogen, nitrite-plus-nitrate nitrogen, total Kjeldahl nitrogen, and total phosphorus. These nutrients were chosen based on data availability and consistency. Surface-water-quality data for 1973-93 were examined because these data were the most current available at this writing and span a sufficient period of record for assessment of trends. Assessment of groundwater nutrients was limited to nitrate nitrogen and data for the period of record were used.

\section{Environmental Setting}

The SANT study area is located in the southeastern United States in central South Carolina and western North Carolina (fig. 1) and has a drainage area of about $23,600 \mathrm{mi}^{2}$. The Santee River is the second largest river on the east coast of the United States and its basin makes up about 65 percent of the study area. The Santee River flows about $415 \mathrm{mi}$ from the mountains of North Carolina to the Atlantic Ocean. Several coastal drainages, primarily the Cooper, Edisto, Salkahatchie, and Coosawhatchie Rivers, make up the remaining 35 percent of the study area (fig. 1). Each of these rivers originates in the Coastal Plain or in the southernmost part of the Piedmont and range in length from less than $10 \mathrm{mi}$ for the smaller creeks to $150 \mathrm{mi}$ for the Edisto River. The lower reaches of the rivers are brackish and affected by tides.

\section{Physiography}

The study area extends across parts of three physiographic provinces--the Blue Ridge, the Piedmont, and the Coastal Plain. The Blue Ridge is a mountainous region with steep slopes, swift streams, and abundant bedrock outcroppings. The bedrock is composed of Paleozoic-age metamorphic and meta-igneous rocks, which are generally covered by a thin layer of weathered bedrock or saprolite. The province is about $70 \mathrm{mi}$ in width in the southeastern Unites States, but only the easternmost part of the province is located in the SANT study area. In general, streams cut across geologic boundaries and are not controlled by the underlying bedrock structure, probably because the bedrock has little variation in hardness. In the study area, Blue Ridge elevations range from 1,500 to $6,000 \mathrm{ft}$ above sea level.

The Piedmont province is characterized by rolling hills, gentle slopes, and low relief. Stream bottoms in the Piedmont can be bedrock, sand, or silt. Near the Blue Ridge, the Piedmont can be similar to the Blue Ridge with isolated outliers of Blue Ridge-like topography and vegetation. The bedrock consists of strongly deformed, resistant Paleozoic metamorphic and metaigneous rocks. Structural control on stream development is limited to the small streams; the larger streams cross gneiss, schist, and granite without significant change in pattern. The boundary between the Blue Ridge and Piedmont is roughly defined where elevations abruptly increase to above $1,500 \mathrm{ft}$. The surface of the Piedmont generally slopes toward the coast and the province ends at the Fall Line where the metamorphic rocks are overlain by Coastal Plain sediments. The Fall Line is an irregular boundary marked by rapids or falls on most major rivers and is at an elevation of about 400 to $600 \mathrm{ft}$ above sea level.

The Coastal Plain slopes gently from the Fall Line toward the coast. Older beds crop out near the Fall Line and successively younger beds are exposed toward the coast. The deposits range in age from Cretaceous to Holocene and are composed of sand, silt, clay, and limestone. The Sand Hills is a subunit of the Coastal Plain that begins at the Fall Line and extends about 20 to $40 \mathrm{mi}$ to the southeast. The Sand Hills are more mature and dissected than the Coastal Plain deposits closer to the coast. The elevations in the Sand Hills range from 300 to $800 \mathrm{ft}$ and there is 150 to $350 \mathrm{ft}$ of local relief. The southeastern boundary of the Sand Hills is marked by an abrupt change to lower relief and elevation. The area below this boundary is called the lower Coastal Plain. The lower Coastal Plain is characterized by marine terraces that were produced by Pleistocene marine transgression. Elevations range from $200 \mathrm{ft}$ to near sea level with little relief. The terraces are low-elevation, low-relief features that are interrupted 


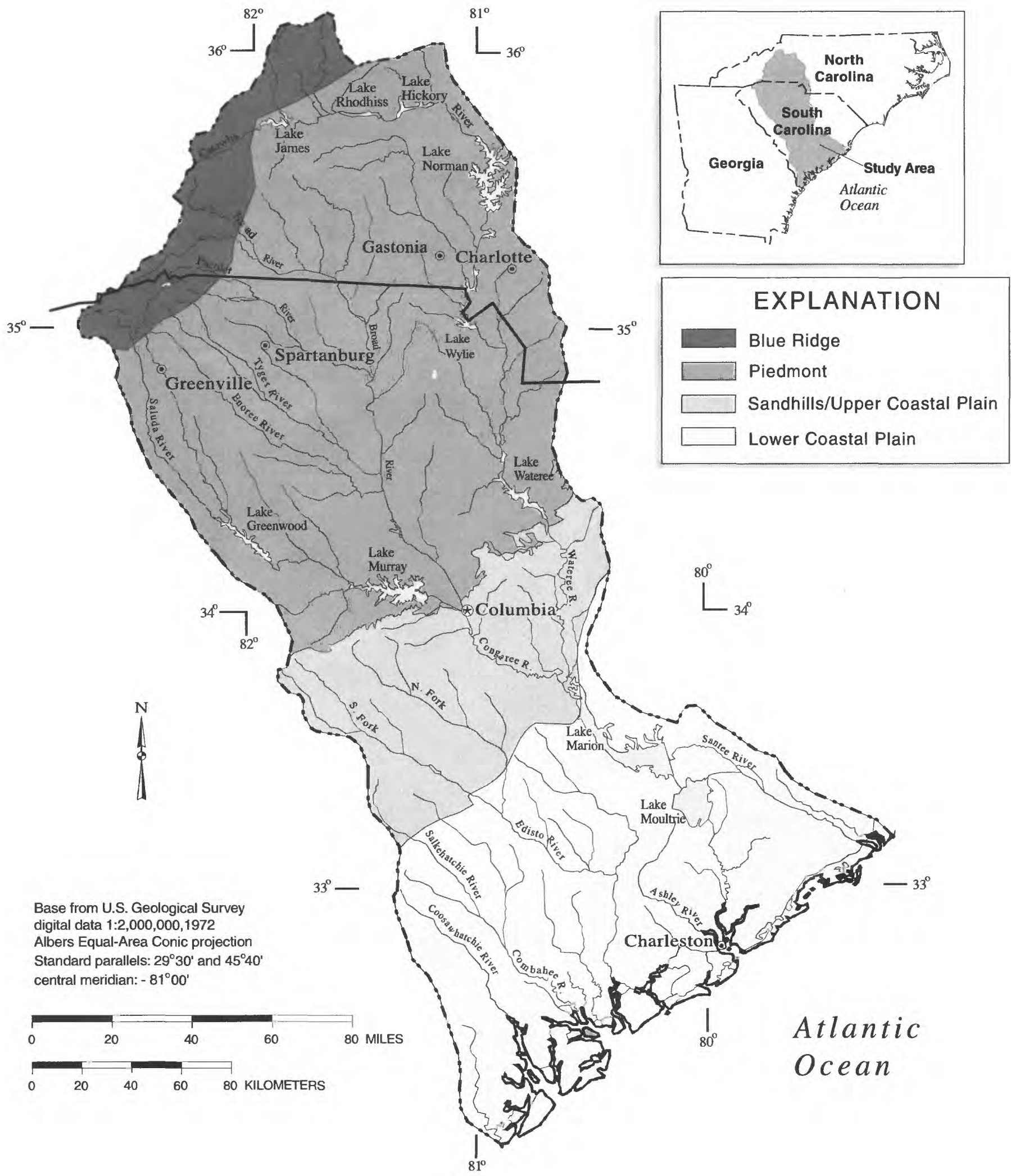

Figure 1. Physiographic provinces of the SANT study area. 
at various points by short escarpments that represent different stands of sea level. About 20 to $30 \mathrm{mi}$ from the Atlantic Ocean, the land surfaces become increasingly isolated by tidal marsh and estuaries, eventually forming numerous islands. Barrier islands are present along the shore.

\section{Climate}

The climate in the study area is generally characterized by short, wet winters and long, hot summers. The annual mean temperature is about $61^{\circ} \mathrm{F}$ and ranges from about $55^{\circ} \mathrm{F}$ in the mountains to $66^{\circ} \mathrm{F}$ along the southern coast. Elevation is the primary factor affecting temperature in the mountains. Along the coast, air temperatures are moderated by the ocean and tidal bodies, which have a smaller annual variation in temperature than the air. The daily range in air temperature is about 6 to $8^{\circ} \mathrm{F}$ greater in the central part of South Carolina than it is on the coast (S.C. Water Resources Commission, 1983). The growing season ranges from about 200 days in the upper part of the study area to about 300 days near the coast.

The annual mean precipitation in the study area is about 48 inches per year (in/yr). Precipitation is greatest in the mountains where the mean ranges up to $80 \mathrm{in} / \mathrm{yr}$ and is least in central South Carolina, where it is $46 \mathrm{in} / \mathrm{yr}$. Immediately along the coast the precipitation is also high, averaging up to $52 \mathrm{in} / \mathrm{yr}$. Rainfall is greatest in the summer months, especially along the coast and in the mountains. Frozen precipitation falls in the study area occasionally in the winter months, but generally melts within a few hours to days except in the mountains. Severe droughts occur about once every 15 years and less widespread and severe droughts every 7 years (S.C. Water Resources Commission, 1983).

\section{Surface-Water Hydrology}

Streamflow in the study area varies with season, geographic location, and physiography. Evapotranspiration is a major factor affecting streamflow, generally resulting in low summer flows and higher winter flows. In the summer months when vegetation is at its peak, evapotranspiration can capture nearly all of the infiltrating water, resulting in insufficient ground water available to support streamflow. The Blue Ridge and upper Coastal Plain have lower seasonal variation in streamflows than the other provinces. The Blue Ridge has abundant year-round precipitation that keeps ground-water levels high, which in turn supplies ample baseflow to streams. In the upper Coastal Plain, thick sandy soils provide a large volume of ground-water storage to supply baseflow. In the lower Coastal Plain, relief is low and little ground water is available to support baseflows. Many streams in this area are intermittent, with no flow for days or weeks in the summer months.

Major rivers draining the study area include the Santee, Cooper, and Edisto Rivers (fig. 1). Much of the flow from the Santee River is diverted across a drainage divide from Lake Marion to Lake Moultrie in the Cooper River Basin. Consequently the flow in the Cooper River Basin is high in relation to its drainage area. Surface-water streamflows from these rivers are summarized in table 1.

Table 1. Streamflows of major rivers draining the SANT study area (U.S. Geological Survey gaging station number in parentheses) (from Cooney and others, 1994 and 1996)

[Units in cubic feet per second]

\begin{tabular}{|c|c|c|c|c|}
\hline Station & $\begin{array}{l}\text { Period } \\
\text { of } \\
\text { record }\end{array}$ & $\begin{array}{l}\text { Annual } \\
\text { mean } \\
\text { flow }\end{array}$ & $\begin{array}{c}\text { Lowest } \\
\text { daily } \\
\text { mean } \\
\text { flow }\end{array}$ & $\begin{array}{l}\text { Highest } \\
\text { daily } \\
\text { mean } \\
\text { flow }\end{array}$ \\
\hline $\begin{array}{l}\text { Santee River } \\
\text { near Jamestown } \\
(02171700)\end{array}$ & $1987-93$ & 11,410 & 460 & 89,500 \\
\hline $\begin{array}{l}\text { Lake Moultrie } \\
\text { Tailrace Canal } \\
\text { at Moncks } \\
\text { Corner - } \\
\text { Cooper River } \\
\text { (02172002) }\end{array}$ & $1979-93$ & 9,739 & ${ }^{1}-521$ & 33,700 \\
\hline $\begin{array}{l}\text { Edisto River } \\
\text { near Givhans } \\
(02175000)\end{array}$ & $1939-93$ & 2,627 & 252 & 24,100 \\
\hline
\end{tabular}

${ }^{1}$ The negative sign indicates upstream flow because of tidal influence under extreme low-flow conditions.

Large surface-water impoundments in the study area include Lakes Norman (32,510 acres), Murray (51,000 acres), Moultrie (60,400 acres), and Marion (110,600 acres) (fig. 1). Much of the sediment carried by the Santee River is deposited in Lakes Marion and Moultrie; however, some fine-grained sediment moves through the Lake Moultrie spillway and increases the natural sediment load of the Cooper River (Patterson, 1983). The diversion of water from the Santee Basin into the Cooper Basin in 1941 caused a large increase 
in flow in the Cooper River and an increase in erosion and sediment load transported by the river. Because much of the increased sediment load was deposited in Charleston Harbor, water from Lake Moultrie was rediverted into the Santee Basin in 1986.

\section{Ground-Water Hydrology}

Ground-water flow is largely dependent on the geological characteristics of the underlying area. The Blue Ridge and Piedmont are underlain by metamorphosed igneous and sedimentary rocks, with a variably thick layer of saprolite, or weathered rock that covers the bedrock. Although the pore spaces are small, water recharged at the land surface moves slowly downward through the saprolite toward the underlying bedrock. The bedrock has an extremely low permeability, but water flows through fractures in the bedrock. Wells throughout the Piedmont provide water for industry, municipalities, and homes. Generally these are deep wells in joints and fractures in the bedrock. Small supplies of ground water, primarily for domestic uses, are obtained from shallow saprolite wells.

The Coastal Plain is underlain by seaward-thickening layers of sand, silt, clay, and limestone that range from Cretaceous to Holocene in age. These deposits are divided into aquifers, based primarily on lithology, and include the Middendorf, Black Creek, Tertiary Sand, Floridan, and surficial aquifers. In the upper Coastal Plain, ground water flows from upland recharge areas toward discharge areas in major streams and rivers. Some ground water follows deeper flowpaths, moving toward the coast. In the lower Coastal Plain, ground water recharged in the upper Coastal Plain flows toward and discharges near the coast. Usable ground water in the Coastal Plain is located within the pore spaces of coarse-grained deposits and is extensively developed as a water supply for industrial and municipal use.

\section{Land and Water Use}

The 1990 population of the study area was about 3.62 million. The study area contains four major metropolitan areas: Greenville-Spartanburg, Columbia, and Charleston in South Carolina and Gastonia-Charlotte in North Carolina. In the 1970's, urban areas accounted for 6 percent of the study area. Industrial areas tend to be clustered near urban centers, with the largest concentration of industry associated with the Greenville-to-Charlotte urban corridor. About 63 per- cent of the study area was forested. Forested lands included hardwood-dominated forests, pine and mixed hardwood forests, and intensively managed pine forests. Croplands represented 18 percent of the study area in the 1970's. Corn, soybeans, cotton, wheat, and oats were the most common crops grown and represented over 90 percent of the land planted in 1993 (South Carolina Agricultural Statistics Service, 1995; North Carolina Agricultural Statistics, 1993). Hay was grown mostly in livestock areas. Peach and apple orchards were grown in many parts of the study area. Coastal farms produced the largest quantities of tomatoes, melons, and strawberries. About 7 percent was pasture and 4 percent was water. Land-use percentages were determined using data from the USGS geographic information retrieval and analysis system (GIRAS) (Mitchell and others, 1977; U.S. Geological Survey, 1992).

Animal production, including poultry, beef and dairy cattle, and aquaculture, is becoming an important industry in some parts of the study area. Although it accounts for a small percentage of land use, large-scale operations in a confined area could affect water quality.

Withdrawals of ground and surface water for municipal, power generation, agricultural, and industrial uses totaled 6.5 billion gallons per day $(\mathrm{Bgal} / \mathrm{d})$ in 1990. Surface and ground water provided 86 and 14 percent, respectively, of the public water supply. Thermoelectric power generation was the biggest water use and accounted for $5.6 \mathrm{Bgal} / \mathrm{d}$. Industrial use accounted for $425 \mathrm{Mgal} / \mathrm{d}$; municipal use, $347 \mathrm{Mgal} / \mathrm{d}$; and agricultural use, $70 \mathrm{Mgal} / \mathrm{d}$. About 3 percent of the withdrawals were for consumptive uses. Instream use by hydroelectric power plants was $49.3 \mathrm{Bgal} / \mathrm{d}$.

\section{Acknowledgments}

We gratefully acknowledge the Federal, State, and local agencies that contributed data, reports, or technical advice to this project, and Dr. Jim Hussey at the University of South Carolina who provided assistance with statistical methodology. In addition, we thank the members of the SANT study area liaison committee who provided information and assistance.

\section{NUTRIENTS IN SURFACE WATERS}

Nutrients such as nitrogen and phosphorus are required for a healthy aquatic environment. They are the basic building blocks of organisms (Hem, 1985). 
As a result of the eutrophication process, however, nutrient concentrations can reach excessive levels and have undesirable effects on water quality. For example, high concentrations of nutrients can cause excessive growth of algae and (or) aquatic macrophytes. A waterbody with a large algal population will appear green, produce algal toxins, and frequently cause oxygen depletion, fish kills, taste and odor problems, shortened life of water filtration systems, and depreciation of aesthetic and property values. A waterbody with a dense macrophytic population will decrease recreational value.

Nitrogen and phosphorus can enter surface waters through atmospheric deposition during rainfall and dustfall, surface runoff, point-source discharges, and ground-water discharge (U.S. Environmental Protection Agency, 1993). Because these nutrients are absorbed by growing aquatic vegetation, concentrations of the various forms of nitrogen and phosphorus vary seasonally, depending on the amount of vegetation present. Empirical studies indicate that phosphorus is most often the limiting element to growth of phytoplankton in freshwater systems, while nitrogen is limiting in estuarine and marine systems (Westman, 1985).

Natural sources of nitrogen include nitrogen oxides fixed by lightning and emitted from volcanic eruptions, ammonia released from decaying animal and plant matter, and biological fixation of nitrogen gas by certain photosynthetic blue-green algae and some bacterial species (U.S. Environmental Protection Agency, 1993). Man-made sources of nitrogen include treated and untreated wastewater from domestic and industrial activities, surface runoff from urban and agricultural areas, atmospheric deposition by precipitation or dustfall of nitrogen created during combustion of fossil fuels, and nitrogen volatilized from agricultural sources. Elevated levels of nitrogen in surface waters create a concern for drinking water safety, and for the health of the aquatic environment (Klaassen and others, 1986).

Nitrogen transport and transformations in a stream environment are complex processes. These processes include sedimentation, resuspension, volatilization, ammonification of organic material by microorganisms, biological nitrification of ammonium to nitrite and subsequently to nitrate, assimilation and synthesis of ammonium and nitrate by algae and aquatic plants, and denitrification of nitrite and nitrate to form nitrogen gas (U.S. Environmental Protection Agency, 1993).

Natural sources of phosphorus include runoff from soils and weathered minerals. Organic phosphorus from plants and animals represents much of the phosphorus in streams. Man-made sources include wastewater discharges, runoff from agricultural drainages, atmospheric deposition, and phosphate mining, concentrating, and processing activities (Hem, 1985). Elevated concentrations of dissolved phosphorus in surface waters are a concern due to eutrophication potential (Klaassen and others, 1986). As a result, phosphate detergent bans were implemented in North Carolina in 1988 and in South Carolina in 1992 (S.C. Department of Health and Environmental Control, 1995).

\section{Water-Quality Criteria}

The U.S. Environmental Protection Agency (USEPA) aquatic life criteria for total ammonia as nitrogen vary depending on water temperature and $\mathrm{pH}$ (1986). Based on observed water temperature and $\mathrm{pH}$ values in the SANT study area, the chronic criteria for total ammonia nitrogen for waters without cold-water species present would range from just under 1.0 milligram per liter (mg/L) to about $2.8 \mathrm{mg} / \mathrm{L}$. The USEPA drinking water standard for nitrate is $10 \mathrm{mg} / \mathrm{L}$ (1991). No aquatic life or drinking water criteria exist for total Kjeldahl nitrogen. No aquatic life or drinking water criteria exist for total phosphorus; however, the USEPA recommends that instream concentrations of phosphorus not exceed $0.10 \mathrm{mg} / \mathrm{L}$ in flowing waters not entering lakes or impoundments, $0.05 \mathrm{mg} / \mathrm{L}$ in flowing waters at the point of entry to a lake or impoundment, and $0.025 \mathrm{mg} / \mathrm{L}$ within lakes or impoundments (1986).

\section{Methods}

Several hundred stream sites in the SANT study area were sampled for water quality at varying frequencies and duration by Federal, State, and local agencies during 1973-93. Water-quality stations were used in this assessment if they were sampled in 1973-93, samples were collected at least quarterly, and they had no more than 5 continuous years of missing data. There were 90 stations that met these criteria (fig. 2; table 2). Nutrient data consistently available were total ammonia nitrogen, total nitrite-plus-nitrate nitrogen, total Kjeldahl nitrogen, and total phosphorus. 


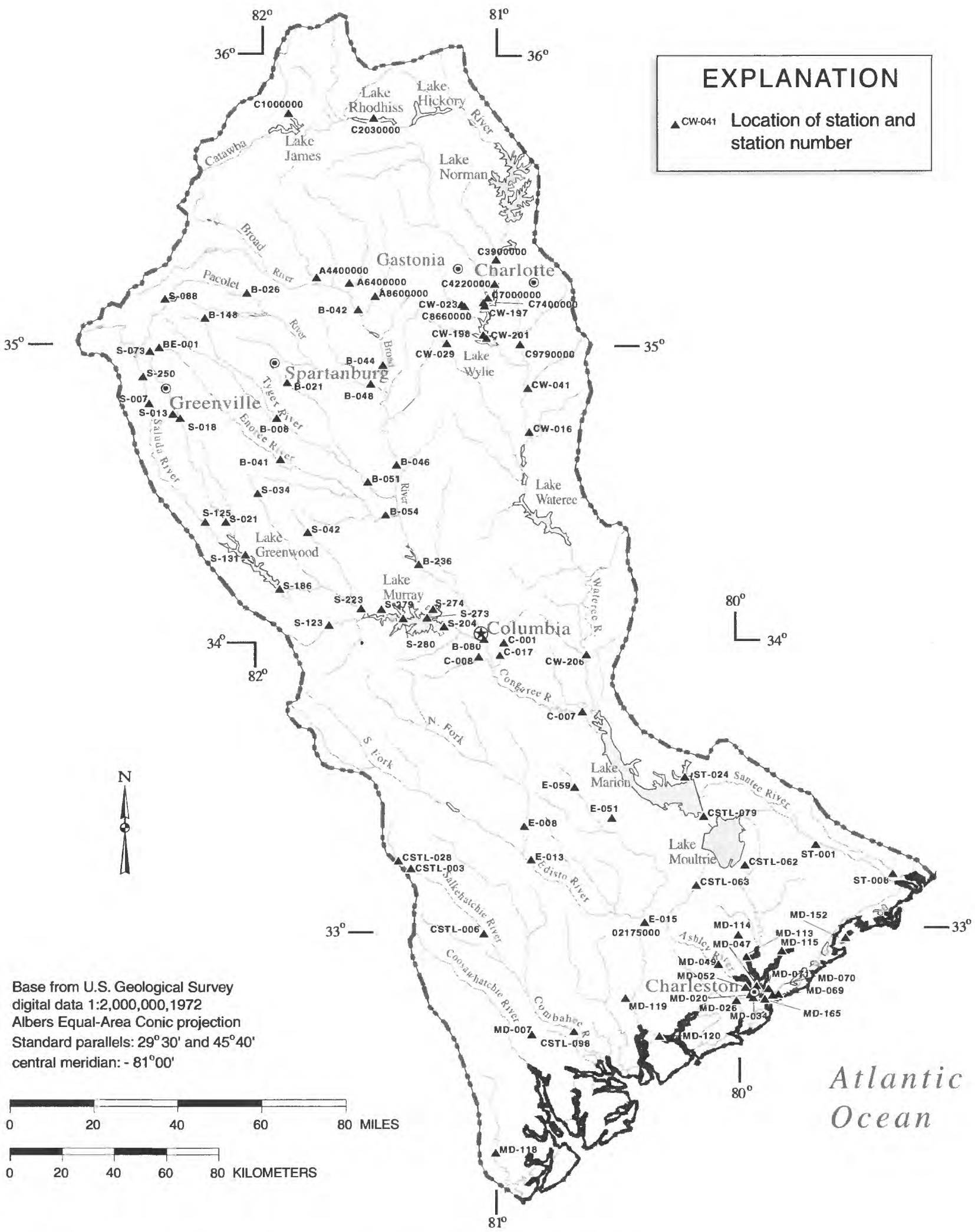

Figure 2. Surface-water-quality stations used for nutrient assessment. 
Table 2. Surface-water-quality stations used for nutrient assessment, SANT study area, 1973-93 [Stream or lake in South Carolina except where indicated]

\begin{tabular}{|c|c|c|}
\hline $\begin{array}{l}\text { Station number } \\
\text { (fig. 2) }\end{array}$ & Location of stream or lake & $\begin{array}{l}\text { Water years of record } \\
\text { from 1973-1993 }\end{array}$ \\
\hline \multicolumn{3}{|c|}{ Broad Subunit } \\
\hline A4400000 & Second Broad River at Cliffside, N.C. & 1973-1991 \\
\hline A6400000 & First Broad River near Earl, N.C. & $1973-1990$ \\
\hline $\mathrm{A} 8600000$ & Buffalo Creek near Grover, N.C. & $1973-1993$ \\
\hline B-008 & Tyger River at county road S-42-50 & $1973-1993$ \\
\hline B-021 & Fairforest Creek at county road S-42-50 & $1973-1993$ \\
\hline B-026 & North Pacolet River at county road S-42-956, east of Landrum & $1973-1993$ \\
\hline B-041 & Enoree River southeast of Woodruff & $1973-1993$ \\
\hline B-042 & Broad River at S.C. road 18 , northeast of Gaffney & $1973-1993$ \\
\hline B-044 & Broad River at S.C. road 18 , northeast of Gaffney & $1973-1993$ \\
\hline B-046 & Broad River near Carlisle & $1973-1993$ \\
\hline B-048 & Pacolet River at S.C. road 105 & $1973-1993$ \\
\hline B-051 & Tyger River southwest of Carlisle & $1973-1993$ \\
\hline B-054 & Enoree River 3.5 miles above Broad River & $1973-1993$ \\
\hline B-080 & Broad River at canal in Columbia & $1973-1993$ \\
\hline B-148 & Middle Tyger River above confluence with Wateree River & $1973-1993$ \\
\hline B-236 & Broad River above confluence with Wateree River & $1973-1993$ \\
\hline BE-001 & Tributary to Enoree River at Travelers Rest & $1973-1993$ \\
\hline C-001 & Gills Creek at Forest Acres & $1973-1993$ \\
\hline C-007 & Congaree River above confluence with Wateree River & $1973-1993$ \\
\hline C-008 & Congaree Creek at Cayce intake & $1973-1993$ \\
\hline C-017 & Gills Creek at Bluff Road & $1973-1993$ \\
\hline S-007 & Saluda River at S.C. road 81 & $1973-1993$ \\
\hline S-013 & Reedy River 3.9 miles southeast of Greenville & $1973-1993$ \\
\hline S-018 & Reedy River near Conestee & $1975-1993$ \\
\hline S-021 & Reedy River near Ware Shoals & 1973-1993 \\
\hline S-034 & Little River at Laurens & 1973-1993 \\
\hline S-042 & Bush River south of Joanna & $1973-1993$ \\
\hline S-073 & Reedy River east of Travelers Rest & $1973-1993$ \\
\hline S-088 & North Saluda River northwest of Tigerville & $1974-1993$ \\
\hline$S-123$ & Little Saluda River at county road S-41-39 & $1973-1993$ \\
\hline S-125 & Saluda River at Ware Shoals & $1973-1993$ \\
\hline S-131 & Lake Greenwood at U.S. road 221 & $1973-1993$ \\
\hline
\end{tabular}


Table 2. Surface-water-quality stations used for nutrient assessment, SANT study area, 1973-93--Continued [Stream or lake in South Carolina except where indicated]

\begin{tabular}{|c|c|c|}
\hline $\begin{array}{l}\text { Station number } \\
\text { (fig. 2) }\end{array}$ & Location of stream or lake & $\begin{array}{l}\text { Water years of record } \\
\text { from 1973-1993 }\end{array}$ \\
\hline S-186 & Saluda River at S.C. road 34 & $1973-1993$ \\
\hline S-204 & Lake Murray at dam at spillway & 1973-1993 \\
\hline $\mathrm{S}-223$ & Lake Murray at Blacksgate Bridge & $1973-1993$ \\
\hline$S-250$ & Saluda River at Farrs Bridge & $1973-1993$ \\
\hline S-273 & Lake Murray at Marker 166 & 1973-1993 \\
\hline S-274 & Lake Murray at Marker 143 & $1973-1993$ \\
\hline S-279 & Lake Murray at Marker 63 & 1973-1993 \\
\hline S-280 & Lake Murray at Marker 102 & 1973-1993 \\
\hline \multicolumn{3}{|c|}{ Catawha Subunit } \\
\hline $\mathrm{C} 1000000$ & Linville River near Nebo, N.C. & $1973-1993$ \\
\hline C2030000 & Lake Rhodiss near Baton, N.C. & $1979-1993$ \\
\hline C3900000 & Catawba River near Thrift, N.C. & $1974-1993$ \\
\hline $\mathrm{C} 4220000$ & Catawba River arm of Lake Wylie, N.C. & 1978-1993 \\
\hline C7000000 & South Fork Catawba River near South Belmont, N.C. & $1975-1993$ \\
\hline C7400000 & Catawba Creek at secondary road 2302 & 1973-1993 \\
\hline $\mathrm{C} 8660000$ & Crowders Creek near Bowling Green & 1973-1993 \\
\hline C9790000 & Sugar Creek near Fort Mill & 1976-1993 \\
\hline CW-016 & Catawba River at Fort Lawn & 1973-1993 \\
\hline CW-023 & Crowders Creek at county road S- $46-564$ & 1973-1993 \\
\hline CW-029 & Fishing Branch at S.C. road 49 & 1973-1993 \\
\hline CW-041 & Catawba River at S.C. road 5 & $1974-1993$ \\
\hline CW-197 & Lake Wylie near Lakewood subdivision at Ebeneezer access & 1973-1993 \\
\hline CW-198 & Lake Wylie at downstream of Crowders Creek arm & 1973-1993 \\
\hline CW-201 & Lake Wylie near Lakewood subdivision at Ebeneezer access & 1973-1993 \\
\hline CW-206 & Wateree River at U.S. roads 76 and 378 & 1973-1993 \\
\hline \multicolumn{3}{|c|}{ Cooper Subunit } \\
\hline CSTL-062 & Tail Race Canal below Lake Moultrie & 1973-1993 \\
\hline CSTL-063 & Wassamassaw Swamp at U.S. road 176 & 1973-1993 \\
\hline CSTL-079 & Diversion canal 12.6 miles west of St. Stephens & 1973-1993 \\
\hline MD-020 & Wappoo Creek between Markers 3 and 4 & 1973-1993 \\
\hline MD-026 & Stono River at S.C. road 700 & 1973-1993 \\
\hline MD-034 & Ashley River at mouth of James Island Creek & $1973-1993$ \\
\hline MD-047 & Town Creek under Grace Memorial Bridge & 1973-1993 \\
\hline MD-049 & Ashley River at Magnolia Gardens & 1973-1993 \\
\hline
\end{tabular}


Table 2. Surface-water-quality stations used for nutrient assessment, SANT study area, 1973-93--Continued [Stream or lake in South Carolina except where indicared]

\begin{tabular}{|c|c|c|}
\hline $\begin{array}{l}\text { Station number } \\
\text { (fig. 2) }\end{array}$ & Location of stream or lake & $\begin{array}{l}\text { Water years of record } \\
\text { from 1973-1993 }\end{array}$ \\
\hline MD-052 & Ashley River at South Atlantic Railroad bridge & $1973-1993$ \\
\hline MD-069 & Intracoastal Waterway at S.C. road 703 east of Mount Pleasant & $1973-1993$ \\
\hline MD-070 & Intracoastal Waterway at Pitt Street, Mount Pleasant & $1973-1993$ \\
\hline MD-071 & Shem Creek at U.S. road 17 & $1973-1993$ \\
\hline MD-113 & Goose Creek Reservoir at Charleston Public Works intake & $1973-1993$ \\
\hline MD-114 & Goose Creek at county road S-10-52 & 1973-1993 \\
\hline MD-115 & Wando River at S.C. road 41 & $1973-1993$ \\
\hline $\mathrm{MD}-152$ & Cooper River at county road S- $08-503$ & $1973-1993$ \\
\hline MD-165 & Charleston Harbor at Fort Johnson Pier & $1973-1993$ \\
\hline ST-001 & Santee River at U.S. road 17A & $1973-1993$ \\
\hline ST-006 & South Santee River at U.S. road 17 & $1973-1993$ \\
\hline ST-024 & Lake Marion at Camp Bob Cooper & $1974-1993$ \\
\hline \multicolumn{3}{|c|}{ Edisto Subunit } \\
\hline 02175000 & Edisto River at S.C. road 61 & $1975-1992$ \\
\hline CSTL-003 & Salkehatchie River at S.C. road 61 & $1973-1993$ \\
\hline C STL-006 & Salkehatchie River at U.S. road 601 & $1973-1993$ \\
\hline CSTL-028 & Salkehatchie River 2 miles west of Barnwell & $1973-1993$ \\
\hline CSTL-098 & Combahee River 10 miles east-southeast of Yemassee & $1973-1993$ \\
\hline $\mathrm{E}-008$ & North Fork Edisto River west-southwest of Rowesville & $1973-1993$ \\
\hline E-013 & Edisto River at U.S. road 78 & $1973-1993$ \\
\hline E-015 & Edisto River at S.C. road 61 & $1973-1993$ \\
\hline E-051 & Providence Swamp at U.S. road 176 & $1973-1993$ \\
\hline E-059 & Four Hole Swamp at U.S. road 176 & $1973-1993$ \\
\hline MD-007 & Pocotaligo River at U.S. road 17 & $1973-1993$ \\
\hline MD-118 & New River 9 miles west of Bluffton & $1973-1993$ \\
\hline MD-119 & Edisto River at U.S. road 17 & $1973-1993$ \\
\hline MD-120 & Dawhoo River at S.C. road 174 & $1973-1993$ \\
\hline
\end{tabular}

Note: The station numbers used in this report are those used by the S.C. Department of Health and Environmental Control (SCDHEC), the N.C. Department of Environment, Health and Natural Resources (NCDEHNR), or the U.S. Geological Survey (USGS). The USGS gaging stations used for streamflow (and the corresponding water-quality stations) are: 02156500 (B-046), 02160105 (B-051), 02160700 (B-054), 02161000 B-236), 02165000 (S-021), 02163500 (S-125), and 02167000 (S-186). 
Most of the surface-water-quality data used in this report were collected by the North Carolina Department of Environment, and Natural Resources (NCDENR) and the South Carolina Department of Health and Environmental Control (SCDHEC) as part of ambient water-quality sampling programs, and archived in the USEPA Storage and Retrieval (STORET) database. Most stations were sampled monthly. In addition, data from one USGS water-quality station were used. Streamflow data were collected by the USGS. Atmospheric data were collected as part of the National Atmospheric Deposition Program/ National Trends Network (NADP/NTN). Fertilizer and manure application data were provided by Richard Alexander (U.S. Geological Survey, written commun., September 16, 1992) and the USEPA. Point-source data were obtained from the USEPA Permit Compliance System (PCS) database. Most of the data used for this assessment were in computerized databases.

The study area was divided into four subunits for assessment: the Broad (40 stations), the Catawba (16 stations), the Cooper (20 stations), and the Edisto (14 stations) (fig. 3). Surface-water stations chosen for assessment include streams, reservoirs, and tidal systems. Streamflows were not generally measured during routine monthly grab samples, nor were streamflow gages located at most of the water-quality sampling stations; therefore, it was not possible to adjust waterquality data for streamflow.

Reporting limits of various species of nutrients have changed over time. Sampling and analytical method improvements often result in lower detection limits, and therefore lower reporting limits. When data with multiple reporting limits are assessed together, spurious decreasing temporal trends in concentrations may be indicated (Flegal and Coale, 1989). Reported nutrient concentrations from some stations were almost entirely below reporting limits after 1990 . The nutrient data from these stations were not censored. Data shown in figures and listed in tables are presented as they were stored in the source database. The reporting limit shown in boxplots represents the most common limit observed in each data set.

Much of the data in this report are summarized graphically as truncated boxplots (Helsel and Hirsch, 1992). Boxplots are a valuable tool to illustrate data variability, skewness, central tendency, and range. Seasonal trends also are demonstrated using boxplots of historical monthly concentrations. Boxplots shown in this report are from stations where at least 10 samples were collected. Boxplots are truncated at the 10 th and 90th percentiles, and extreme values (those greater than the 90 th percentile and less than the 10 th percentile) are not displayed. Because the data are used as reported in the databases, values reported as "less than" are used in statistical analysis as the reported value (the reporting limit). This lack of censoring may result in the reporting limit being shown as several percentiles on boxplots. For example, at a station with 100 of 180 results below the reporting limit, the median (50th percentile), the 10 th and the 25 th percentiles all will be the reporting limit. The bottom whisker will not show, and the 25 th and 50th percentile lines will overlap at the reporting limit.

Spatial trends of nutrient concentrations in surface water were assessed using boxplots of percentiles calculated for the period of record at each station. Temporal trends of nutrient concentrations were assessed using several methods. Scatter plots of concentrations over time were created to reveal the general variance in the data over time. Cumulative values of the various parameters over time were plotted, and differences in slopes for the period of record were assessed. Due to space restrictions, not all analyses that were performed are presented graphically.

Temporal trend analyses were performed using the seasonal Kendall test (Hirsch and others, 1982). This test is based on the nonparametric Kendall's Tau test (Kendall, 1975), appropriate in cases where the data are not always normally distributed, some of the data are censored, or in cases of nonconstant variance and occasional outliers. The seasonal Kendall test is designed to detect monotonically increasing or decreasing temporal trends in water-quality data where seasonality exists. A significance level (alpha) of 0.05 was used, meaning that the acceptable error of not detecting a trend where one actually exists was five percent.

Loads were calculated at seven stations where concurrent streamflow and water-quality data were available. Two methods were used. The first method involved using daily mean streamflows and monthly water-quality data to calculate monthly and annual medians of streamflow and nutrient concentration. These medians were then used to calculate median monthly and annual loads. 


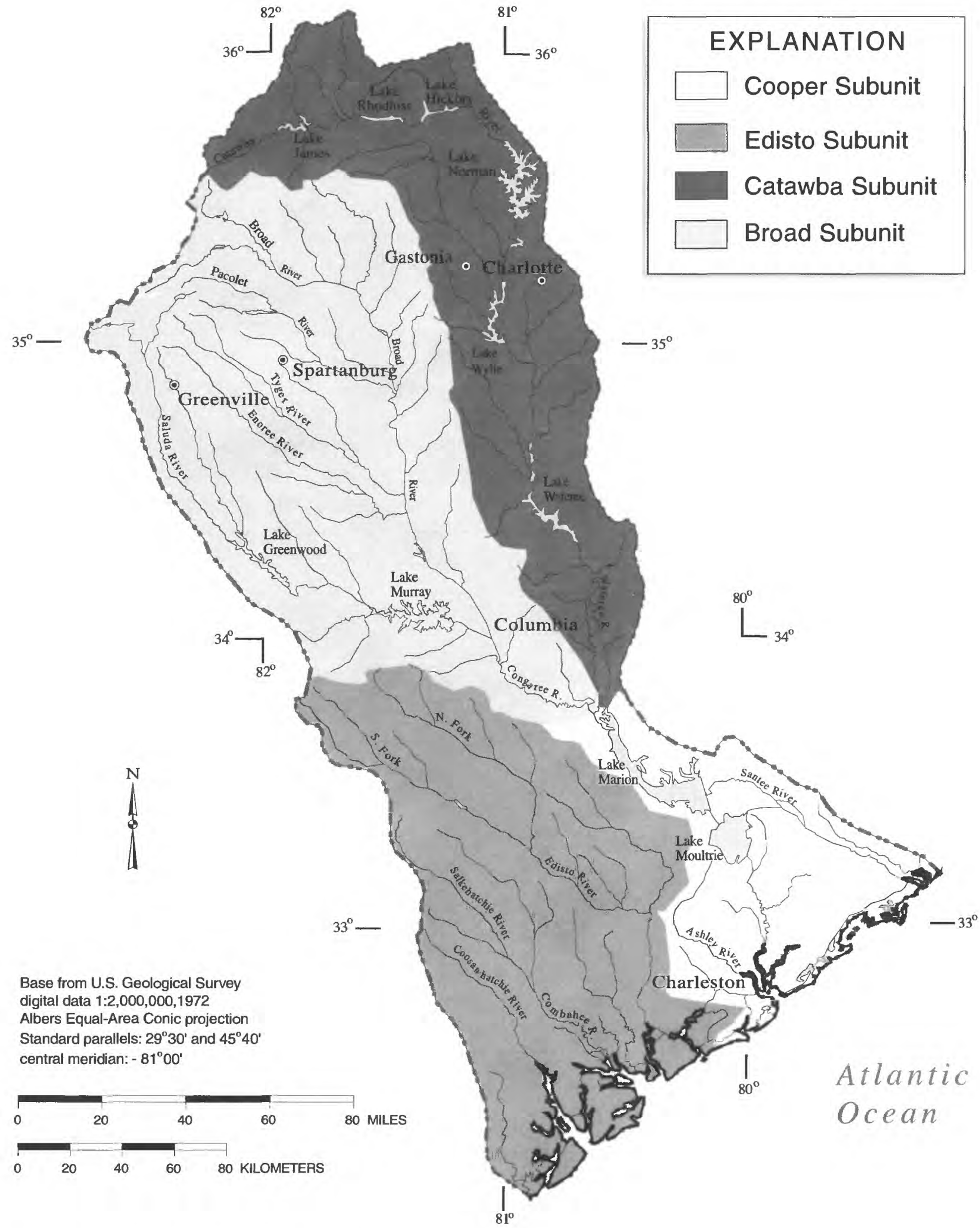

Figure 3. Subunits in the SANT study area. 
Of the seven stations, four were located in the Broad River drainage basin and three were located in the Saluda River drainage basin. Estimated loads at the upstream-most station in each drainage basin were compared with the estimated loads at the downstreammost station, accounting for any tributary and incremental inflows where possible. This method of estimating monthly and annual loads likely underestimates the actual loads during storm events, because routine water-quality samples were generally not collected during rain or high streamflow events.

A second method was used to estimate annual loads at the same seven stations using the rating-curve method with a program called LOADEST2 (Cohn and others, 1989; Crawford, 1991). Some of the concentrations in the data set were below the detection limit, therefore parameters of the rating curve were estimated by maximum-likelihood methods (Dempster and others, 1977; Wolynetz, 1979) or the linear attribute method (Chatterjee and McLeish, 1986). A detailed description of these methods is given in Crawford (1996). The LOADEST2 program is limited to 10 years of daily streamflow data, so the period from October 1980 through September 1990 was selected. Predicted loads generated by the LOADEST2 program were compared with measured loads. Percentage differences between predicted and measured loads were calculated and graphed. Because nutrient concentration and streamflow at these seven stations were poorly correlated, and because few water-quality samples were available during high streamflows, errors of estimates were quite large, often up to 500 percent and at times as high as 1,200 percent. Therefore, results of this method of load estimation are not presented here.

\section{Broad Subunit}

The Broad subunit is located in the Blue Ridge, Piedmont, and Coastal Plain physiographic provinces (fig. 3). Major cities include Greenville, Spartanburg, and Columbia, S.C. Significant surface-water bodies include the Broad, Saluda, Reedy, Enoree, Tyger, and Congaree Rivers, and Lakes Greenwood and Murray. Land use was mainly forest and agriculture, with scattered urban areas. More streams are impacted by pointsource discharges in urban areas in the Broad subunit than in the other three subunits.

Median ammonia nitrogen concentrations ranged from 0.05 to $1.6 \mathrm{mg} / \mathrm{L}$ (fig. 4). The Reedy River near Conestee (S-018) had the highest median ammo- nia nitrogen concentration $(1.6 \mathrm{mg} / \mathrm{L})$ with a range of below detection to $8.3 \mathrm{mg} / \mathrm{L}$. Concentrations of the 75 th and the 90 th percentiles at this station were 3.30 and $4.60 \mathrm{mg} / \mathrm{L}$, respectively (not shown in fig 4). Fairforest Creek near Spartanburg (B-021) had the second highest median concentration of ammonia nitrogen $(0.32 \mathrm{mg} / \mathrm{L})$ with a range of below detection to 3.9 $\mathrm{mg} / \mathrm{L}$. The Reedy River and Fairforest Creek are impacted by upstream wastewater discharges and urban runoff. Both creeks had low streamflows relative to the volume of wastewater received, therefore little dilution of the wastewater occurred and instream nutrient concentrations remained high. The Little Saluda River (S-123) and Gills Creek at Bluff Road (C-017) had the next highest concentrations of ammonia nitrogen among the remaining stations in the Broad subunit. Elevated concentrations of ammonia nitrogen may have exceeded the chronic criteria for aquatic life protection, depending on the $\mathrm{pH}$ and temperature of the stream at the time.

Median nitrite-plus-nitrate nitrogen concentrations in the Broad subunit ranged from 0.04 to 1.55 $\mathrm{mg} / \mathrm{L}$ (fig. 5). Fairforest Creek (B-021) had the highest concentration of $1.55 \mathrm{mg} / \mathrm{L}$, with a range of 0.25 to 5.9 $\mathrm{mg} / \mathrm{L}$. Two Reedy River stations (S-018 and S-021) had median nitrite-plus-nitrate concentrations above $1.0 \mathrm{mg} / \mathrm{L}$.

Median total Kjeldahl nitrogen concentrations ranged from 0.22 to $3.4 \mathrm{mg} / \mathrm{L}$. The Reedy River (S-018) had the highest median concentration of 3.4 $\mathrm{mg} / \mathrm{L}$, with a range of 0.37 to $14.8 \mathrm{mg} / \mathrm{L}$ (fig. 6). Concentrations of the 75th and the 90th percentiles at this station were 5.1 and $7.2 \mathrm{mg} / \mathrm{L}$, respectively (not shown in fig. 6). Fairforest Creek (B-021) had the second highest median total Kjeldahl nitrogen concentration of $1.01 \mathrm{mg} / \mathrm{L}$. Total Kjeldahl nitrogen represents the sum of ammonia nitrogen plus organic nitrogen. High total Kjeldahl nitrogen concentrations at these two stations were correlated with high ammonia nitrogen concentrations, as well as high levels of organic nitrogen.

Median total phosphorus concentrations in the Broad subunit ranged from 0.05 to $1.00 \mathrm{mg} / \mathrm{L}$ (fig. 7). The Reedy River (S-018) had the highest median concentration of $1.00 \mathrm{mg} / \mathrm{L}$, with a range of below detection to $11.00 \mathrm{mg} / \mathrm{L}$. Other stations with elevated medians include Fairforest Creek (B-021), Bush River (S-042), Reedy River near Ware Shoals (S-021), Buffalo Creek (A8600000), and the Little Saluda River (S123). These streams all exceeded the USEPA recommended maximum concentrations of phosphorus. 


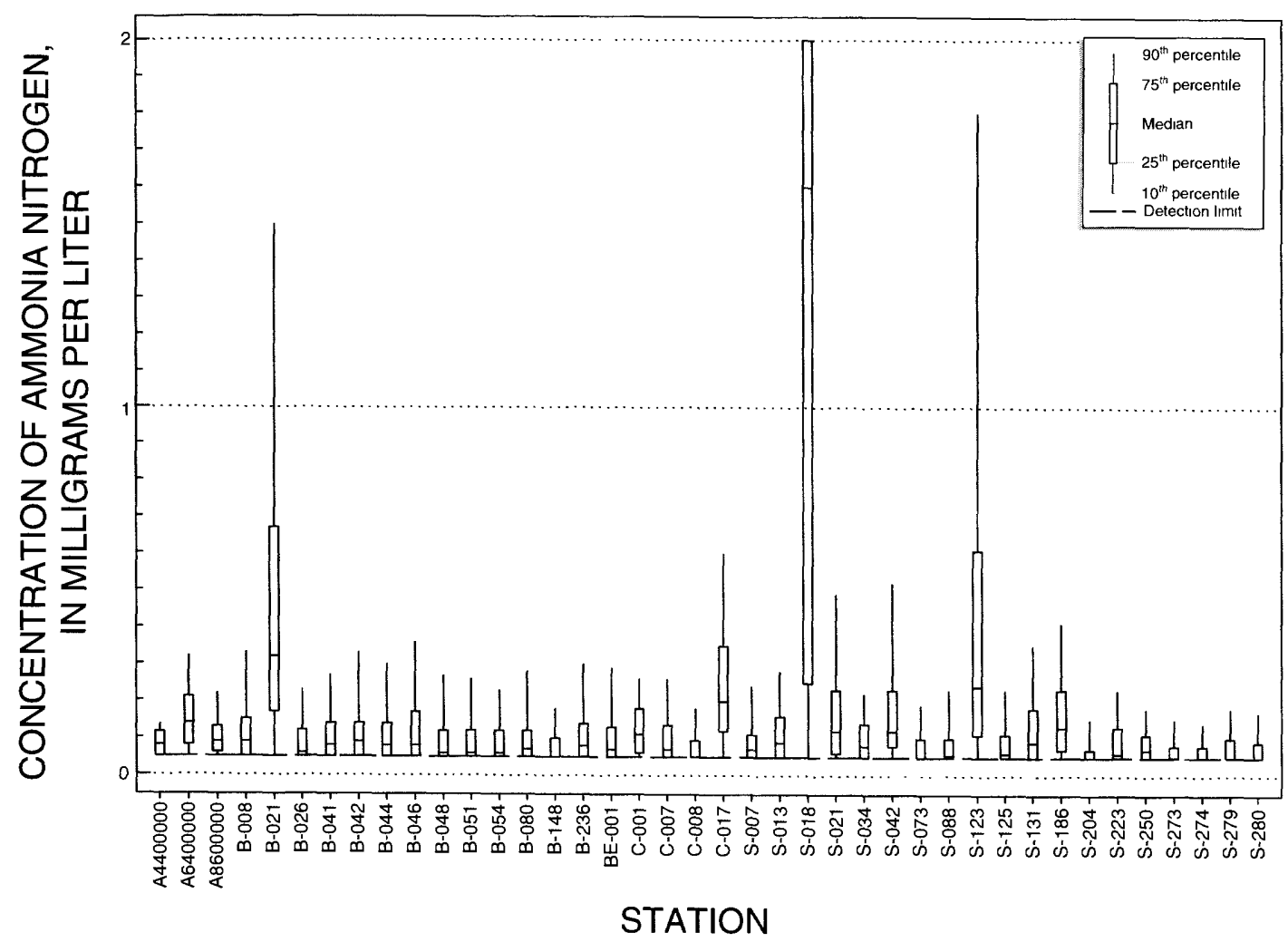

Figure 4. Ammonia nitrogen concentrations in the Broad subunit, SANT study area, 1973-93.

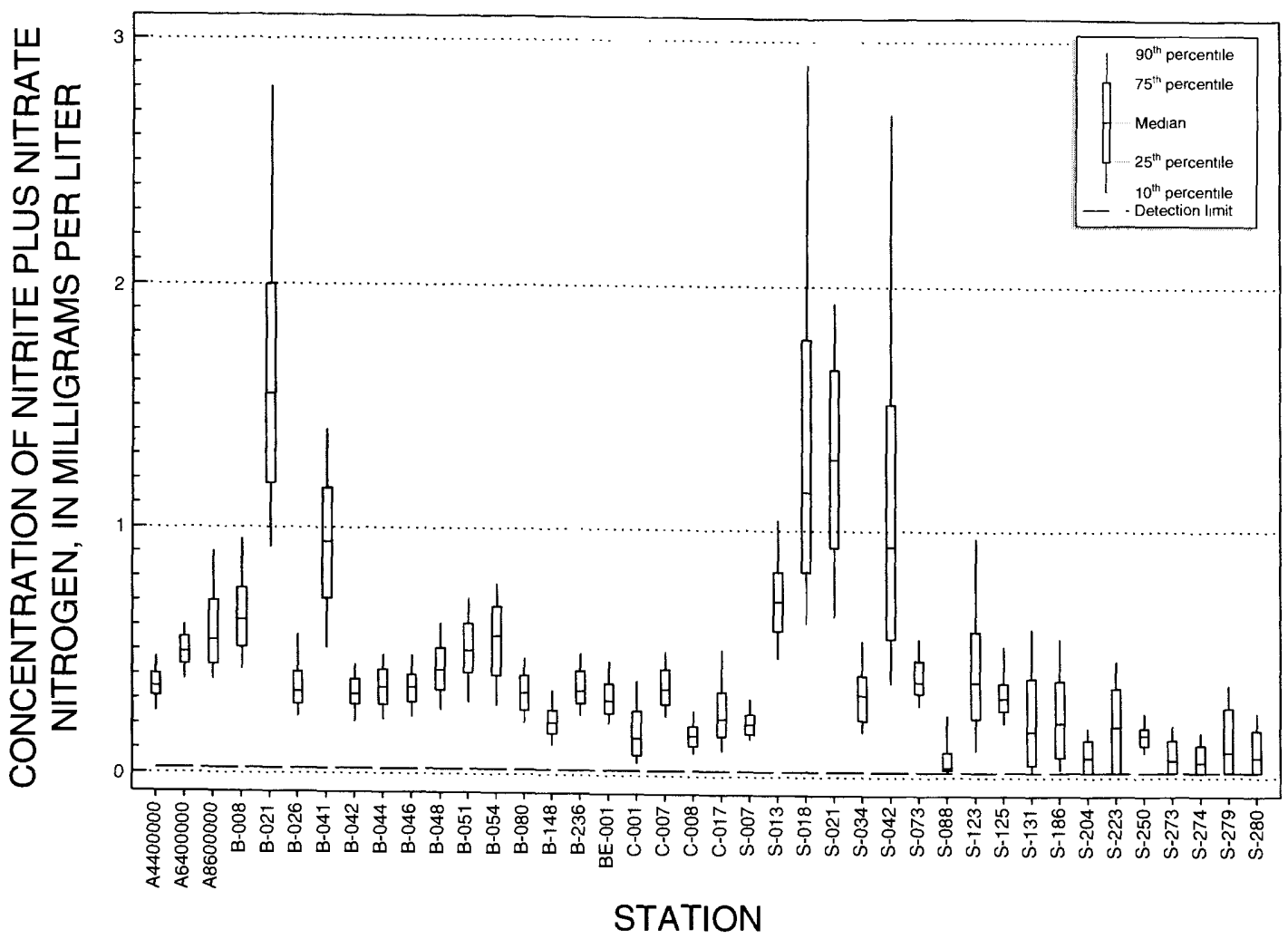

Figure 5. Nitrite-plus-nitrate nitrogen concentrations in the Broad subunit, SANT study area, 1973-93. 


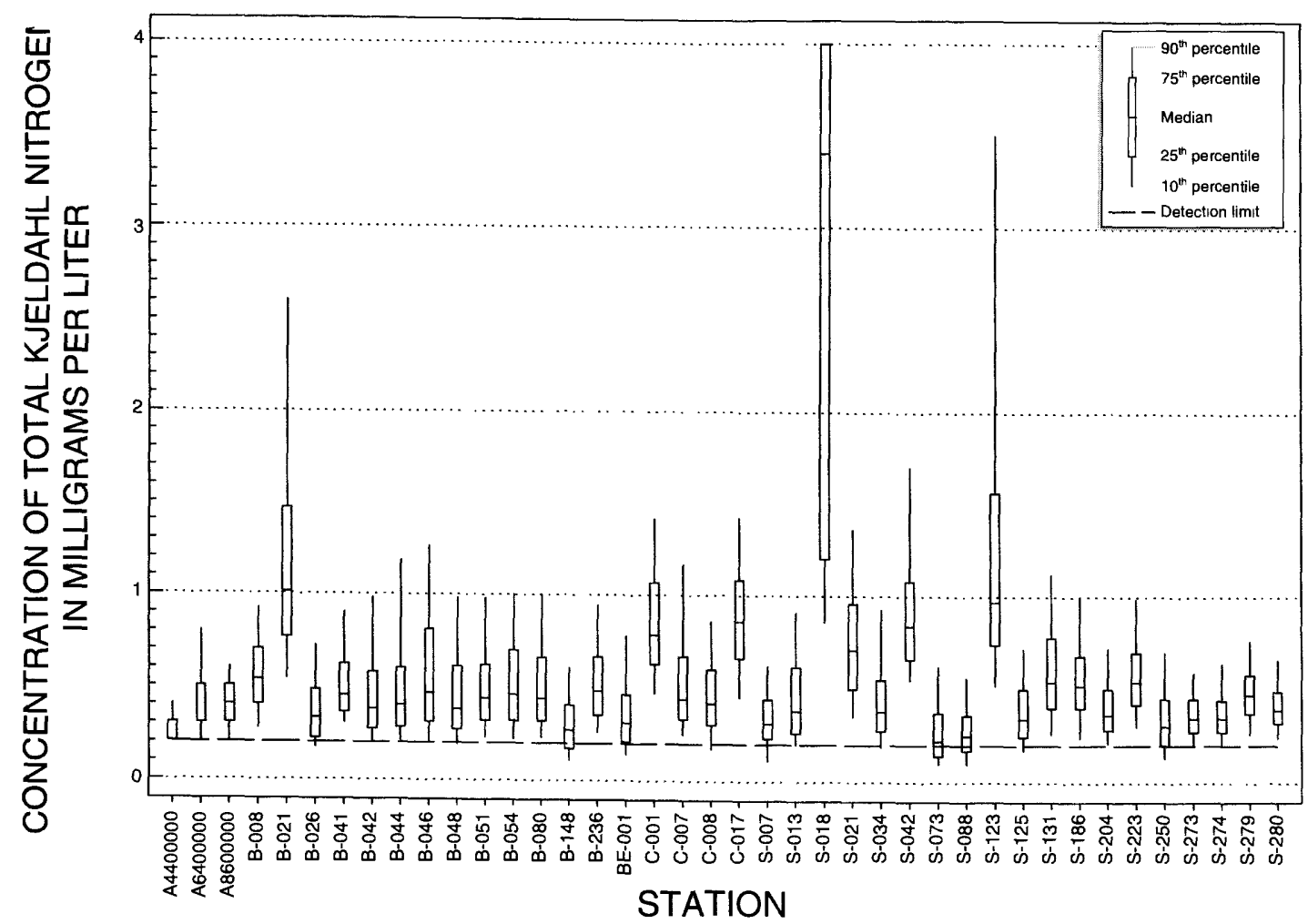

Figure 6. Total Kjeldahl nitrogen concentrations in the Broad subunit, SANT study area, 1973-93.

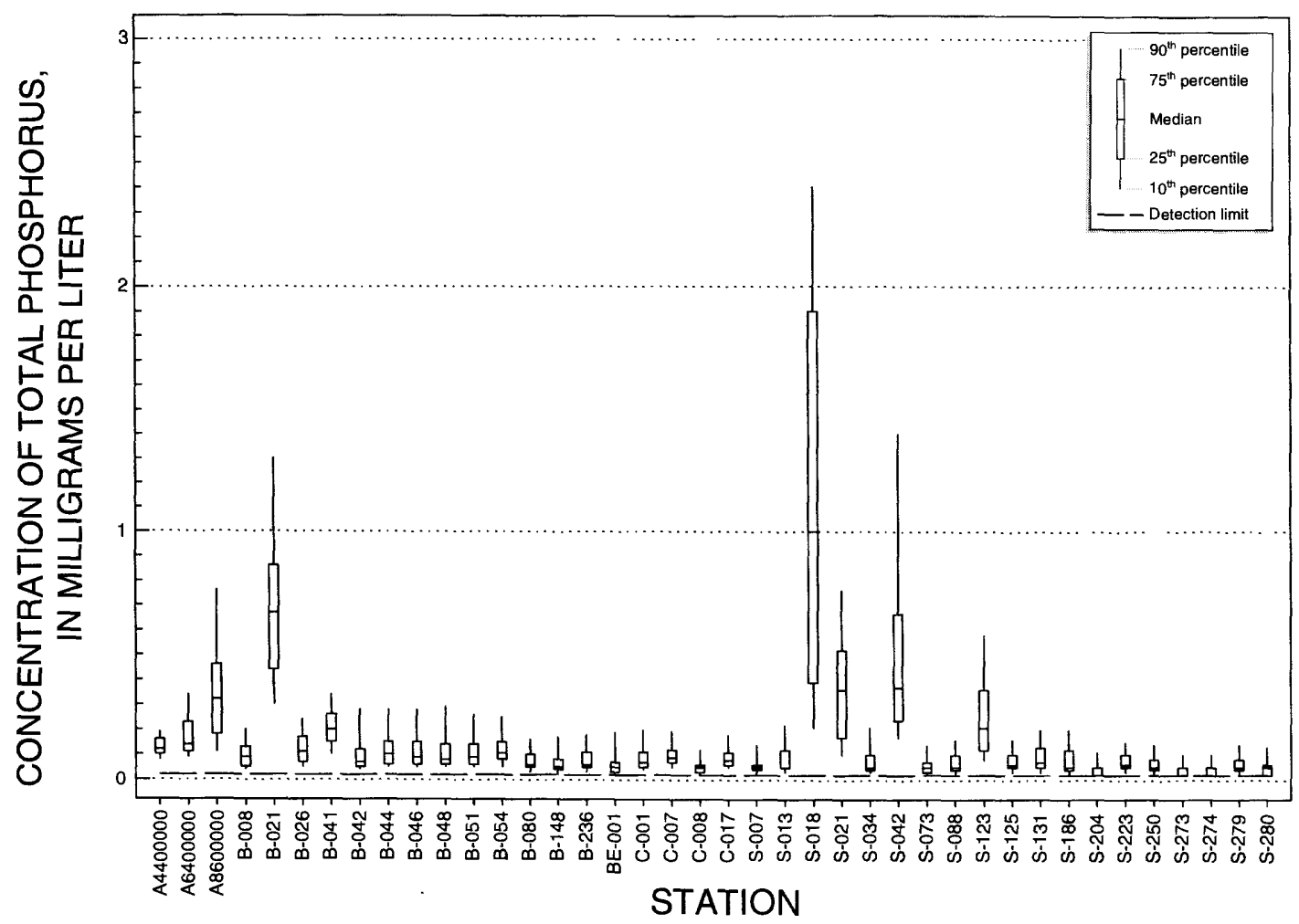

Figure 7. Total phosphorus concentrations in the Broad subunit, SANT study area, 1973-93. 
Elevated levels of instream total phosphorus generally indicate impact from point-source discharges or agricultural activities in the drainage basin.

Temporal trends of ammonia nitrogen were assessed in the Broad subunit. Seventeen of the forty stations had statistically significant decreases in ammonia nitrogen for 1973-93 (table 3). Decreases in ammonia nitrogen concentrations most likely reflect higher levels of wastewater treatment. There were no stations with statistically significant increases in ammonia nitrogen. Twenty-three stations showed no trend.

Twenty-two of the 40 stations in the Broad subunit showed significant decreases in nitrite-plus-nitrate nitrogen concentrations (table 3 ). Four stations showed significant increases: Buffalo Creek (A8600000), the Second Broad River (A4400000), and the Enoree River (B-041 and B-054). Changes in agricultural practices and levels of wastewater treatment influence nitriteplus-nitrate nitrogen concentrations in receiving waters. Products of ammonia oxidation include nitrite and nitrate. Wastewater-treatment plants, in upgrading ammonia nitrogen treatment processes, may release higher concentrations of nitrite-plus-nitrate nitrogen (U.S. Environmental Protection Agency, 1993).

Twelve stations in the Broad subunit showed statistically significant decreases in total Kjeldahl nitrogen during 1973-93 (table 3). The First Broad River (A6400000), the Second Broad River (A4400000), and Buffalo Creek (A8600000) showed significant increases in total Kjeldahl nitrogen during 1973-93. Increases may reflect population growth or increased agricultural production. Twenty-five stations showed no trend. Fourteen of the forty stations showed a statistically significant decrease in total phosphorus concentrations during 1973-93 (table 3). Decreases may be due to implementation of phosphate detergent bans in North and South Carolina. There were three stations with significant increases in total phosphorus: Buffalo Creek (A8600000), the First Broad River (A6400000), and the North Pacolet River (B-026). The causes for these increases are unknown, but could be the result of increasing urbanization or from agricultural runoff. Twenty-three stations showed no trend.

Table 3. Temporal nutrient trends in the Broad subunit, SANT study area, 1973-93

[Stream or lake in South Carolina except where indicated; +, increasing trend; -, decreasing trend; $n$, no trend]

\begin{tabular}{|c|c|c|c|c|c|}
\hline $\begin{array}{l}\text { Station number } \\
\text { (fig. 2) }\end{array}$ & Stream or lake & $\begin{array}{c}\text { Ammonia } \\
\text { nitrogen }\end{array}$ & $\begin{array}{l}\text { Nitrite-plus- } \\
\text { nitrate nitrogen }\end{array}$ & $\begin{array}{l}\text { Total Kjeldahl } \\
\text { nitrogen }\end{array}$ & $\begin{array}{l}\text { Total } \\
\text { phos- } \\
\text { phorus }\end{array}$ \\
\hline A4400000 & Second Broad River, N.C. & $\mathrm{n}$ & + & + & $\mathrm{n}$ \\
\hline A6400000 & First Broad River, N.C. & $\mathrm{n}$ & $\mathrm{n}$ & + & + \\
\hline $\mathrm{A} 8600000$ & Buffalo Creek, N.C. & $\mathrm{n}$ & + & + & + \\
\hline B-008 & Tyger River & - & $\mathrm{n}$ & $\mathbf{n}$ & $\mathrm{n}$ \\
\hline B-021 & Fairforest Creek & - & $\mathrm{n}$ & - & - \\
\hline B-026 & North Pacolet River & $\mathrm{n}$ & - & $\mathrm{n}$ & + \\
\hline B-041 & Enoree River & - & + & - & - \\
\hline B-042 & Broad River & $\mathrm{n}$ & $\mathrm{n}$ & $\mathrm{n}$ & $\mathrm{n}$ \\
\hline B-044 & Broad River & - & $\mathrm{n}$ & $\mathrm{n}$ & $\mathrm{n}$ \\
\hline B-046 & Broad River & $\mathrm{n}$ & $\mathrm{n}$ & $\mathrm{n}$ & $\mathrm{n}$ \\
\hline B-048 & Pacolet River & $\mathrm{n}$ & $\mathrm{n}$ & $\mathrm{n}$ & - \\
\hline B-051 & Tyger River & $\mathrm{n}$ & $\mathrm{n}$ & $\mathrm{n}$ & $\mathrm{n}$ \\
\hline
\end{tabular}


Table 3. Temporal nutrient trends in the Broad subunit, SANT study area, 1973-93--Continued

[Stream or lake in South Carolina except where indicated; +, increasing trend; -, decreasing trend; $n$, no trend]

\begin{tabular}{|c|c|c|c|c|c|}
\hline $\begin{array}{l}\text { Station number } \\
\text { (fig. 2) }\end{array}$ & Stream or lake & $\begin{array}{c}\text { Ammonia } \\
\text { nitrogen }\end{array}$ & $\begin{array}{c}\text { Nitrite-plus- } \\
\text { nitrate nitrogen }\end{array}$ & $\begin{array}{l}\text { Total Kjeldahl } \\
\text { nitrogen }\end{array}$ & $\begin{array}{l}\text { Total } \\
\text { phos- } \\
\text { phorus }\end{array}$ \\
\hline B-054 & Enoree River & $\mathrm{n}$ & + & $\mathrm{n}$ & $\mathrm{n}$ \\
\hline B-080 & Broad River & - & - & - & - \\
\hline B-148 & Middle Tyger River & - & - & $\mathrm{n}$ & $\mathrm{n}$ \\
\hline B-236 & Broad River & - & - & - & $\mathrm{n}$ \\
\hline BE-001 & Tributary to Enoree River & - & - & $\mathrm{n}$ & - \\
\hline $\mathrm{C}-001$ & Gills Creek & - & - & $\mathrm{n}$ & $\mathrm{n}$ \\
\hline $\mathrm{C}-007$ & Congaree River & - & $\mathrm{n}$ & - & $\mathrm{n}$ \\
\hline $\mathrm{C}-008$ & Congaree Creek & $\mathrm{n}$ & $\mathrm{n}$ & $\mathrm{n}$ & - \\
\hline $\mathrm{C}-017$ & Gills Creek & $\mathrm{n}$ & - & $\mathrm{n}$ & $\mathrm{n}$ \\
\hline S-007 & Saluda River & - & - & $\mathrm{n}$ & $\mathbf{n}$ \\
\hline S-013 & Reedy River & - & - & - & - \\
\hline S-018 & Reedy River & $\mathrm{n}$ & $\mathrm{n}$ & $\mathrm{n}$ & - \\
\hline S-021 & Reedy River & $\mathrm{n}$ & $\mathrm{n}$ & $\mathrm{n}$ & $\mathrm{n}$ \\
\hline S-034 & Little River & - & - & $\mathrm{n}$ & $\mathrm{n}$ \\
\hline S-042 & Bush River & $\mathrm{n}$ & $\mathrm{n}$ & $\mathbf{n}$ & $\mathrm{n}$ \\
\hline S-073 & Reedy River & $\mathrm{n}$ & - & - & - \\
\hline S-088 & North Saluda River & - & - & - & $\mathrm{n}$ \\
\hline S-123 & Little Saluda River & $\mathbf{n}$ & $\mathrm{n}$ & $\mathrm{n}$ & $\mathrm{n}$ \\
\hline S-125 & Saluda River & $\mathrm{n}$ & - & $\mathrm{n}$ & $\mathrm{n}$ \\
\hline S-131 & Lake Greenwood & $\mathrm{n}$ & - & $\mathrm{n}$ & - \\
\hline S-186 & Saluda River & - & - & - & - \\
\hline S-204 & Lake Murray & $\mathrm{n}$ & - & $\mathrm{n}$ & - \\
\hline S-223 & Lake Murray & - & - & - & $\mathrm{n}$ \\
\hline $\mathrm{S}-250$ & Saluda River & - & - & - & $\mathrm{n}$ \\
\hline S-273 & Lake Murray & $\mathrm{n}$ & - & $\mathbf{n}$ & $\mathrm{n}$ \\
\hline S-274 & Lake Murray & $\mathrm{n}$ & - & - & - \\
\hline S-279 & Lake Murray & $\mathrm{n}$ & - & $\mathrm{n}$ & $\mathrm{n}$ \\
\hline$S-280$ & Lake Murray & $\mathrm{n}$ & - & $\mathrm{n}$ & - \\
\hline
\end{tabular}




\section{Catawba Subunit}

The Catawba subunit is located in the Blue Ridge, Piedmont, and Coastal Plain physiographic provinces. Major cities in the subunit include Gastonia and Charlotte, N.C. Along the Catawba River, the major river in the subunit, several lakes are regulated for power production, including Lakes James, Rhodhiss, Hickory, Norman, Wylie, and Wateree. This subunit is distinct due to its highly regulated surface-water flows. Land use was mainly forest and agriculture, with urban use concentrated in the upper part of the subunit.

Nutrient concentrations and trends were assessed at 16 stations. Median ammonia nitrogen concentrations ranged from 0.05 to $1.60 \mathrm{mg} / \mathrm{L}$ (fig. 8). Sugar Creek (C9790000) had the highest median ammonia nitrogen concentration $(1.60 \mathrm{mg} / \mathrm{L})$ with a range of below detection to $12.00 \mathrm{mg} / \mathrm{L}$. Concentrations of the 75th and the 90th percentiles at this station were 3.70 and $5.60 \mathrm{mg} / \mathrm{L}$, respectively (not shown in fig. 8). This station is impacted by upstream wastewater discharges associated with the city of Charlotte, N.C. As stated previously, elevated concentrations of ammonia nitrogen may have exceeded the chronic criteria for aquatic life protection, depending on simultaneous stream temperature and $\mathrm{pH}$. Other stations with elevated ammonia nitrogen concentrations include Crowder's Creek (CW-023 and C8660000) and the Catawba River (CW-041). These stations are also influenced to varying degrees by upstream wastewater discharges.

Median nitrite-plus-nitrate nitrogen concentrations in the Catawba subunit ranged from 0.11 to 3.50 mg/L (fig. 9). Sugar Creek (C9790000) had the highest median nitrite-plus-nitrate nitrogen concentration $(3.50 \mathrm{mg} / \mathrm{L})$ with a range of 0.19 to $17.00 \mathrm{mg} / \mathrm{L}$. Values for Sugar Creek (C9790000) not shown in figure 9 include the 50 th percentile $(3.50 \mathrm{mg} / \mathrm{L})$, the 75 th percentile $(4.90 \mathrm{mg} / \mathrm{L})$, and the 90 th percentile $(7.80$ $\mathrm{mg} / \mathrm{L}$ ). Other stations with elevated nitrite-plus-nitrate nitrogen concentrations include Crowder's Creek (CW-023 and C8660000) and the Catawba River (CW-041 and CW-016). Stations with elevated nitriteplus-nitrate nitrogen concentrations are influenced to varying degrees by upstream wastewater discharges.

Median total Kjeldahl nitrogen concentrations in the Catawba subunit ranged from 0.10 to $2.80 \mathrm{mg} / \mathrm{L}$ (fig. 10). Sugar Creek (C9790000) had the highest median concentration of $2.80 \mathrm{mg} / \mathrm{L}$, with a range of 0.20 to $11.00 \mathrm{mg} / \mathrm{L}$. Concentrations of the 75 th and the 90th percentiles at this station were 5.00 and 6.80 $\mathrm{mg} / \mathrm{L}$, respectively (not shown in fig. 10). Other stations with elevated total Kjeldahl nitrogen concentrations include Crowder's Creek (C8660000), the Catawba River (CW-016 and CW-041), Lake Wylie (CW-197, CW-198, and CW-201), and the Wateree River (CW-206). Possible causes of elevated total Kjeldahl nitrogen concentrations include upstream wastewater discharges or organic nitrogen input in lakes or slow-moving streams.

Median total phosphorus concentrations in the Catawba subunit ranged from 0.04 to $1.70 \mathrm{mg} / \mathrm{L}$ (fig. 11). Sugar Creek (C9790000) had the highest median concentration $(1.70 \mathrm{mg} / \mathrm{L})$ with a range of 0.07 to 8.60 $\mathrm{mg} / \mathrm{L}$. Concentrations of the 75 th and the 90 th percentiles at this station were 2.60 and $3.70 \mathrm{mg} / \mathrm{L}$, respectively (not shown in fig. 11). Other stations with elevated concentrations of total phosphorus include Crowder's Creek (CW-023 and C8660000) and the Catawba River (CW-016 and CW-041). These streams are all influenced by upstream wastewater discharges.

As in the Broad subunit, temporal trends in the Catawba subunit showed decreasing ammonia nitrogen concentrations, the result of more effective removal of ammonia nitrogen in wastewater over time. Statistically significant decreasing trends in ammonia nitrogen were detected in 5 of the 16 stations, including Sugar Creek (C9790000), the Wateree River (CW-206), and the Catawba River (CW-041). All of these streams are affected by wastewater discharges. An assessment of ammonia nitrogen values at Sugar Creek indicates that the most significant decrease in ammonia nitrogen occurred after 1987. Improvements in wastewatertreatment plant effluent quality in the late 1980's and early 1990's coupled with the decrease in agriculture activities in the Sugar Creek watershed in the 1980's could explain the decreases in ammonia nitrogen (Carla Sanderson, N.C. Department of Environment, Health and Natural Resources, oral commun., 1996). Eleven stations showed no temporal trend (table 4).

Temporal trends in nitrite-plus-nitrate nitrogen were mixed (table 4). Two stations had significantly decreasing concentrations, while four had significantly increasing concentrations. Decreasing trends were found at the Wateree River (CW-206) and Fishing Branch (CW-029), possibly due to land-use changes over the period of study. Increasing trends were found at Crowders Creek (C8660000 and CW-023), Sugar Creek (C9790000), and the Linville River (C1000000). 


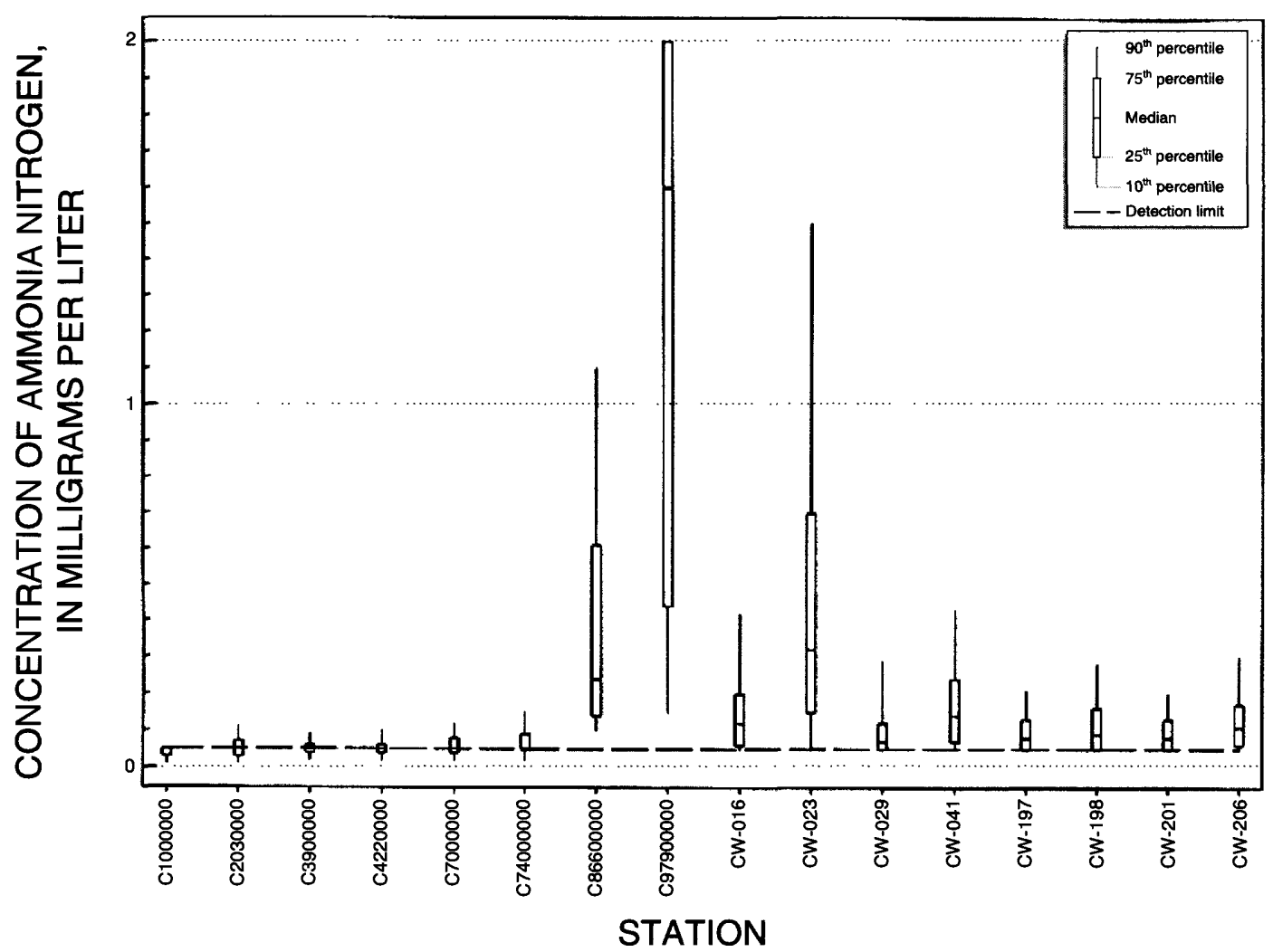

Figure 8. Ammonia nitrogen concentrations in the Catawba subunit, SANT study area, 1973-93.

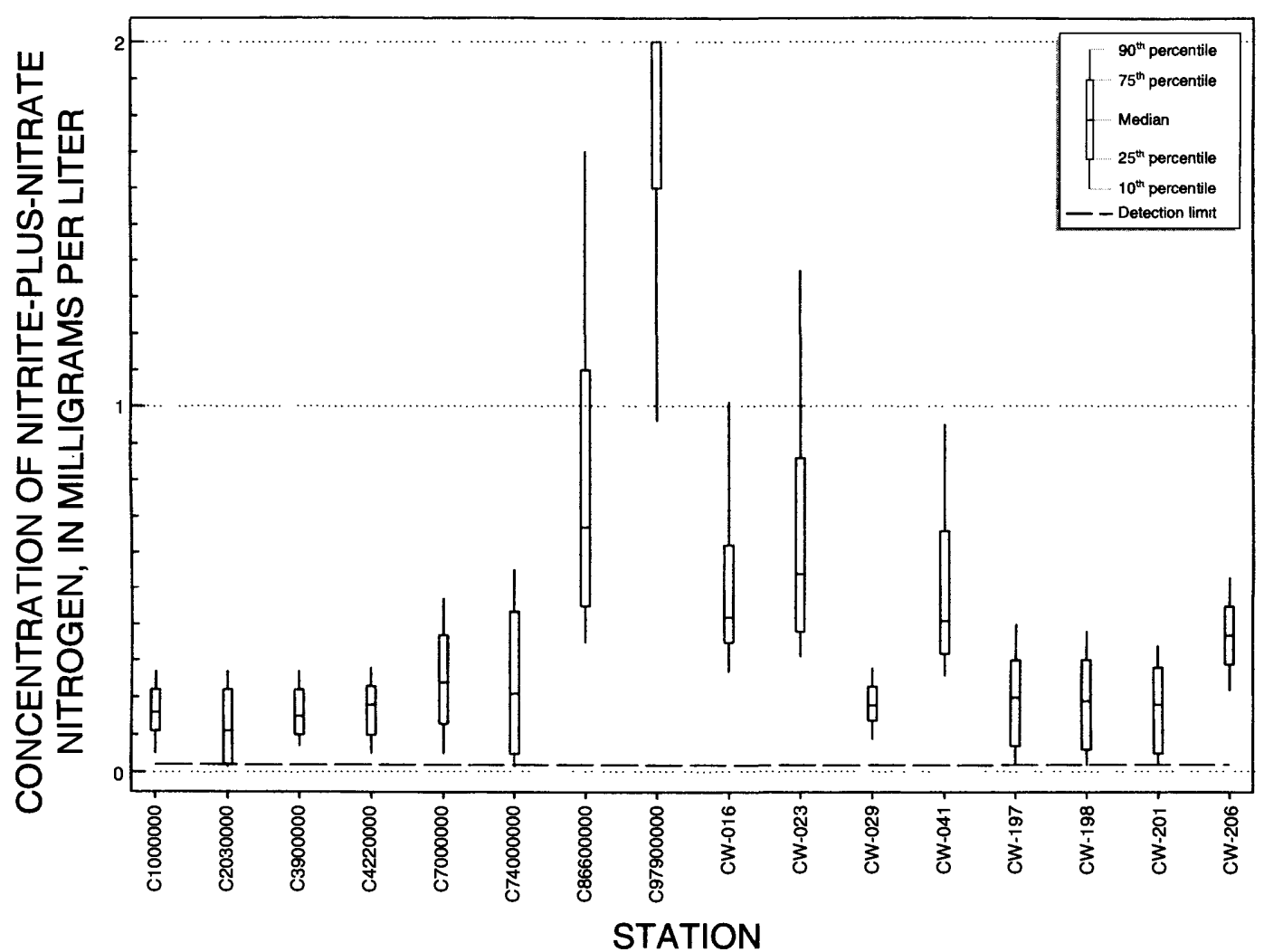

Figure 9. Nitrite-plus-nitrate nitrogen concentrations in the Catawba subunit, SANT study area, 1973-93. 


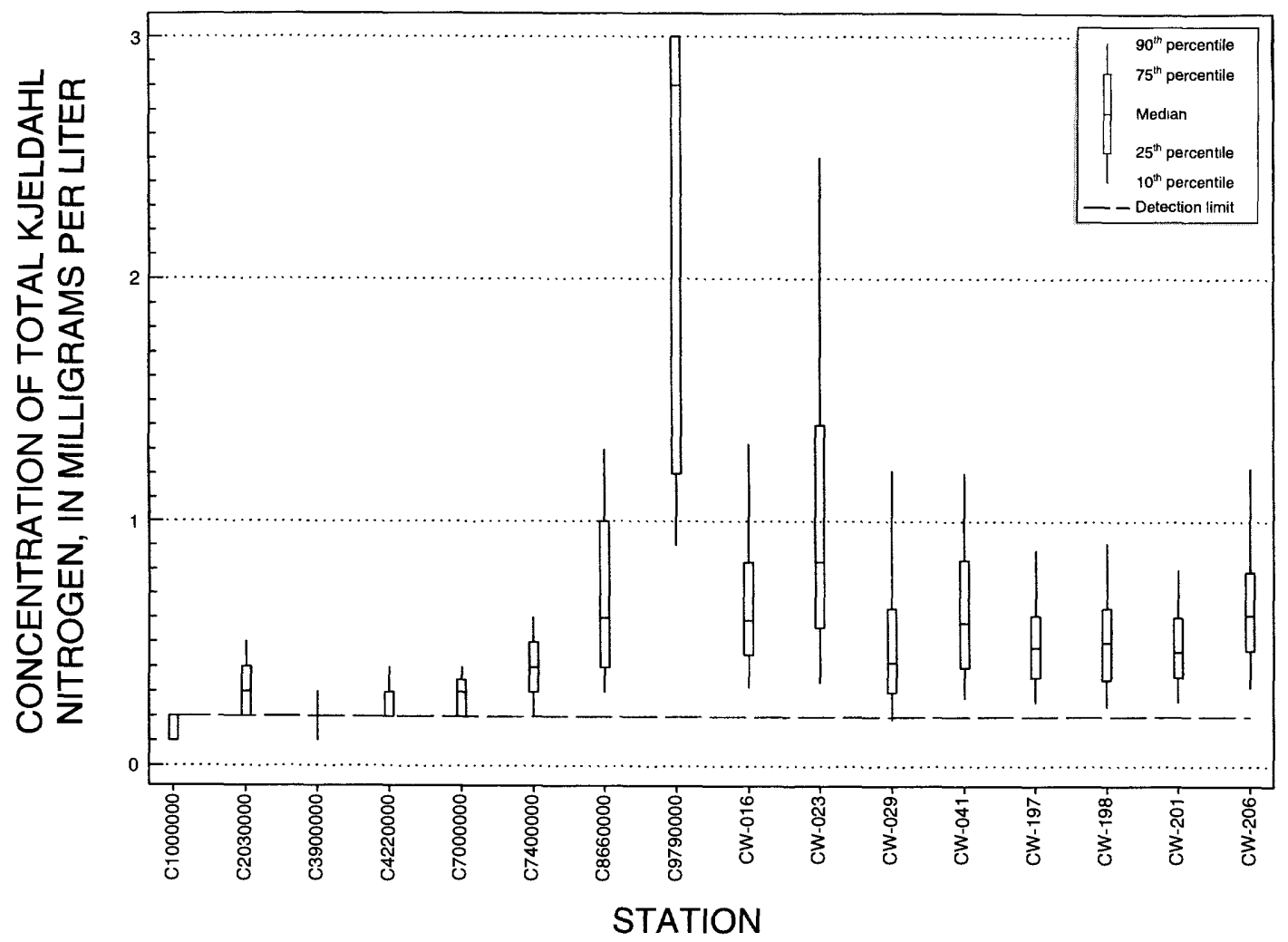

Figure 10. Total Kjeldahl nitrogen concentrations in the Catawba subunit, SANT study area, 1973-93.

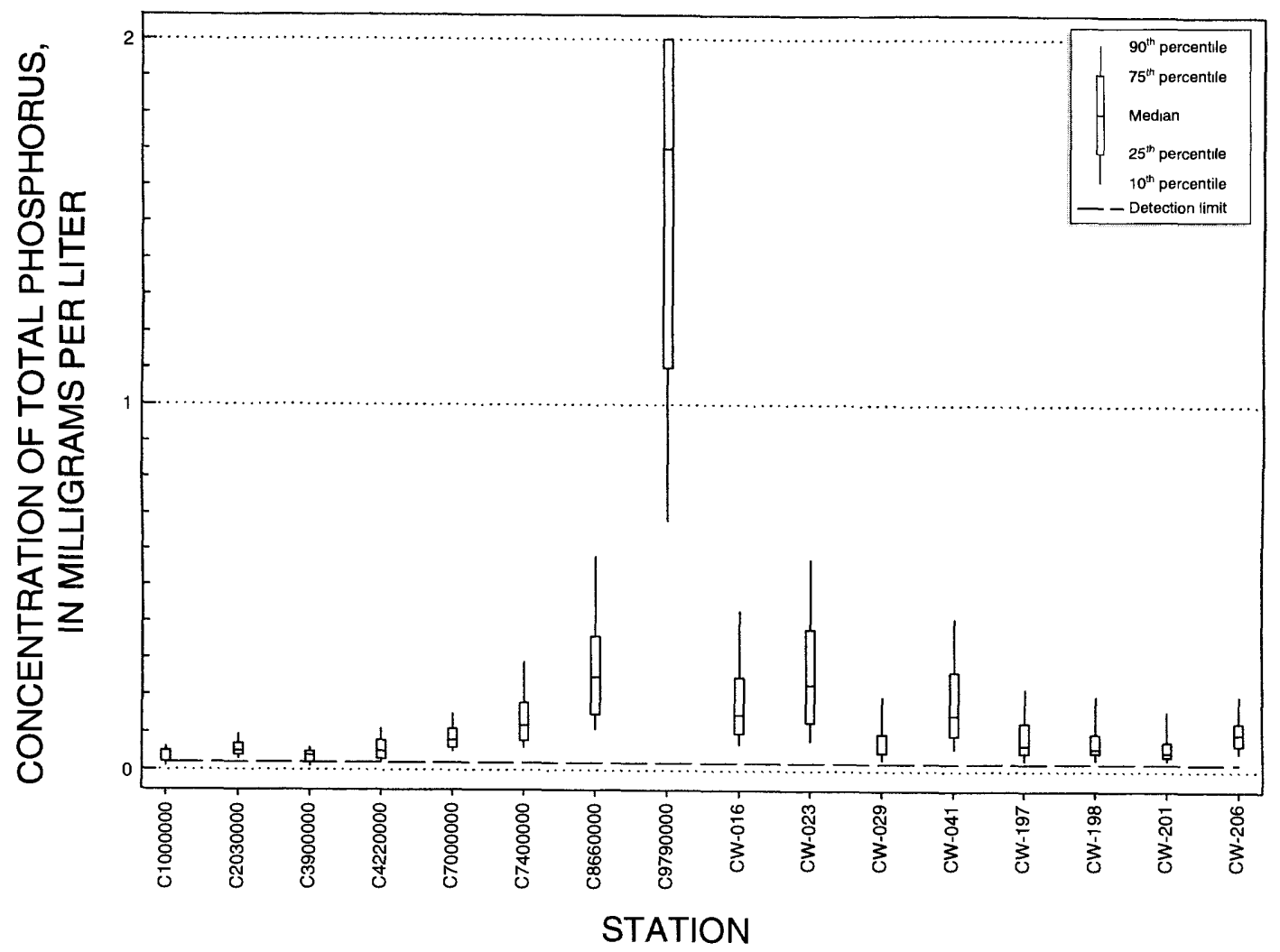

Figure 11. Total phosphorus concentrations in the Catawba subunit, SANT study area, 1973-93. 
Table 4. Temporal nutrient trends in the Catawba subunit, SANT study area, 1973-93

[Stream or lake in South Carolina except where indicated; +, increasing trend; -, decreasing trend; $\mathbf{n}$, no trend]

\begin{tabular}{|c|c|c|c|c|c|}
\hline $\begin{array}{c}\text { Station number } \\
\text { (fig. 2) }\end{array}$ & Stream or Lake & $\begin{array}{c}\text { Ammonia } \\
\text { nitrogen }\end{array}$ & $\begin{array}{c}\text { Nitrite-plus- } \\
\text { nitrate } \\
\text { nitrogen }\end{array}$ & $\begin{array}{l}\text { Total Kjeldahl } \\
\text { nitrogen }\end{array}$ & $\begin{array}{l}\text { Total } \\
\text { phos- } \\
\text { phorus }\end{array}$ \\
\hline $\mathrm{C} 1000000$ & Linville River, N.C. & - & + & $\mathrm{n}$ & - \\
\hline $\mathrm{C} 2030000$ & Lake Rhodiss, N.C. & $\mathbf{n}$ & $\mathbf{n}$ & $\mathrm{n}$ & - \\
\hline C3900000 & Catawba River, N.C. & - & $\mathrm{n}$ & $\mathrm{n}$ & - \\
\hline $\mathrm{C} 4220000$ & Catawba River, N.C. & $\mathrm{n}$ & $\mathrm{n}$ & $\mathrm{n}$ & - \\
\hline $\mathrm{C} 7000000$ & South Fork Catawba River, N.C. & n & $\mathrm{n}$ & $\mathrm{n}$ & $\mathrm{n}$ \\
\hline C7400000 & Catawba Creek & $\mathrm{n}$ & $\mathrm{n}$ & $\mathrm{n}$ & $\mathrm{n}$ \\
\hline $\mathrm{C} 8660000$ & Crowders Creek & $\mathbf{n}$ & + & n & $\mathrm{n}$ \\
\hline C9790000 & Sugar Creek & - & + & - & $\mathrm{n}$ \\
\hline CW-016 & Catawba River & $\mathrm{n}$ & $\mathrm{n}$ & $\mathrm{n}$ & $\mathrm{n}$ \\
\hline $\mathrm{CW}-023$ & Crowders Creek & $\mathbf{n}$ & + & $\mathrm{n}$ & $\mathrm{n}$ \\
\hline CW-029 & Fishing Branch & $\mathbf{n}$ & - & $\mathbf{n}$ & $\mathrm{n}$ \\
\hline CW-041 & Catawba River & - & $\mathrm{n}$ & - & $\mathrm{n}$ \\
\hline CW-197 & Lake Wylie & n & n & n & - \\
\hline CW-198 & Lake Wylie & $\mathrm{n}$ & $\mathbf{n}$ & $\mathrm{n}$ & - \\
\hline CW-201 & Lake Wylie & $\mathrm{n}$ & $\mathrm{n}$ & $\mathrm{n}$ & - \\
\hline CW-206 & Wateree River & - & - & - & $n$ \\
\hline
\end{tabular}

Increasing trends may be due to changes in wastewater treatment processes or changes in land use.

Significantly decreasing temporal trends in total Kjeldahl nitrogen were found at three stations in the Catawba subunit: Sugar Creek (C9790000), the Catawba River (CW-041), and the Wateree River (CW-206) (table 4). These decreases correspond to decreasing trends in ammonia nitrogen.

Statistically significant decreasing temporal trends in total phosphorus were found in 7 of the 16 stations (table 4), including the Catawba River (C3900000 and C4220000), the Linville River (C1000000), Lake Rhodiss (C2030000), and at three Lake Wylie stations (CW-201, CW-197, and CW-198). These decreasing trends are probably a result of a ban on phosphate detergents instituted in 1988 in North Carolina and in 1992 in South Carolina.

\section{Cooper Subunit}

The Cooper subunit is located in the Coastal Plain physiographic province (fig. 3). The only major city in the subunit is Charleston, S.C. The Cooper subunit also contains regulated major rivers, including the Cooper and the Santee. Other major rivers in the subunit include the Ashley and Wando. The lower parts of all the rivers in the subunit are tidally influenced, and a major harbor is located in Charleston. Two large lakes are located in the subunit: Lakes Marion and Moultrie. Regulation of flow from Lakes Marion and Moultrie (after rediversion) controls flows in the Santee River, while regulation of flow from Lake Moultrie controls flows in the Cooper River. Major land uses in the Cooper subunit include forest, wetland, and agriculture. 
Data from 20 stations were assessed in the Cooper subunit. Median ammonia nitrogen concentrations ranged from 0.05 to $0.14 \mathrm{mg} / \mathrm{L}$ (fig. 12). Town Creek at Charleston, S.C., (MD-047) had the highest median ammonia nitrogen concentration $(0.14 \mathrm{mg} / \mathrm{L})$ with a range of below detection to $2.90 \mathrm{mg} / \mathrm{L}$. This station is located downstream from several major point-source discharges, including one with elevated concentrations of ammonia nitrogen. Median concentrations of ammonia nitrogen were generally lower and less variable than those of the Broad and Catawba subunits.

Median nitrite-plus-nitrate nitrogen concentrations ranged from below detection to $0.23 \mathrm{mg} / \mathrm{L}$ (fig. 13). The Ashley River at Magnolia Gardens (MD049) had the highest median concentration of $0.23 \mathrm{mg} /$ $\mathrm{L}$, with a range of below detection to $3.24 \mathrm{mg} / \mathrm{L}$. This station is located downstream from several municipal and industrial point-source discharges. Concentrations were generally lower in the Cooper subunit than the Broad and Catawba subunits, with all 90th percentile concentrations below $0.5 \mathrm{mg} / \mathrm{L}$.

Median total Kjeldahl nitrogen concentrations ranged from 0.49 to $1.06 \mathrm{mg} / \mathrm{L}$ (fig. 14). The Ashley River (MD-049) had the highest median concentration $(1.06 \mathrm{mg} / \mathrm{L})$ with a range of 0.10 to $7.80 \mathrm{mg} / \mathrm{L}$. Wassamassaw Swamp (CSTL-063) and Goose Creek (MD114) also had elevated concentrations. Slow-moving swamps and estuarine areas often have high levels of organic material, including organic nitrogen, which accounts for elevated levels of total Kjeldahl nitrogen.

Median total phosphorus concentrations in the Cooper subunit ranged from 0.05 to $0.40 \mathrm{mg} / \mathrm{L}$ (fig. 15). The Ashley River (MD-049) had the highest median concentration $(0.40 \mathrm{mg} / \mathrm{L})$ with a range of 0.05 to $1.40 \mathrm{mg} / \mathrm{L}$ total phosphorus. Other stations with elevated median concentrations include Goose Creek (MD-114) and Goose Creek Reservoir (MD-113). Total phosphorus concentrations were more variable than other nutrient concentrations in the Cooper subunit.

Temporal trends of ammonia nitrogen showed statistically significant decreases at 6 of the 20 stations (table 5). There were no stations with significant increases of ammonia nitrogen. Nineteen of the twenty stations in the subunit showed statistically significant trends in nitrite-plus-nitrate nitrogen (table 5). The Ashley River (MD-049) showed an increasing trend. This may be because of better ammonia nitrogen removal efficiency at upstream wastewater-treatment plants, resulting in higher concentrations of nitrite- plus-nitrate nitrogen in the effluent. Eighteen stations showed decreasing trends. Scatter plots of the data showed higher concentrations in the 1970's, leveling off in the 1980's and 1990's. The Ashley River (MD-052) showed no trend.

Five of the twenty stations had statistically significant decreasing temporal trends in total Kjeldahl nitrogen (table 5). Nine of the 20 stations had statistically significant decreasing trends in total phosphorus (table 5). No stations had increasing trends in total Kjeldahl nitrogen or total phosphorus.

\section{Edisto Subunit}

The Edisto subunit is located mainly in the Coastal Plain physiographic province. Orangeburg and Beaufort, S.C., are the only moderate-sized cities in the Edisto subunit. Major rivers include the New, Coosawhatchie, Salkehatchie, and Edisto Rivers. There are no large lakes in the subunit. Major land uses included forest, agriculture, and wetlands. The Edisto subunit includes many blackwater streams, with their characteristic dark color.

Data from 14 stations were assessed in the Edisto subunit. Median ammonia nitrogen concentrations ranged from 0.02 to $0.14 \mathrm{mg} / \mathrm{L}$ (fig. 16). The Pocotaligo River (MD-007) had the highest median ammonia nitrogen concentration $(0.14 \mathrm{mg} / \mathrm{L})$ with a range of below detection to $15.00 \mathrm{mg} / \mathrm{L}$. All ammonia nitrogen data at the USGS Edisto River station (02175000) fell below the most common detection limit of the STORET data.

Median nitrite-plus-nitrate nitrogen concentrations ranged from 0.03 to $0.45 \mathrm{mg} / \mathrm{L}$ (fig. 17). Four Hole Swamp (E-059) had the highest median nitriteplus-nitrate nitrogen concentration of $0.45 \mathrm{mg} / \mathrm{L}$, with a range of 0.03 to $1.77 \mathrm{mg} / \mathrm{L}$. Providence Swamp (E-051) also had an elevated median nitrite-plus-nitrate nitrogen concentration $(0.44 \mathrm{mg} / \mathrm{L})$. These stations are located in an agricultural region of the study area and are impacted by nonpoint sources of nutrients, but are still relatively low compared to concentrations found in the Broad and Catawba subunits. 


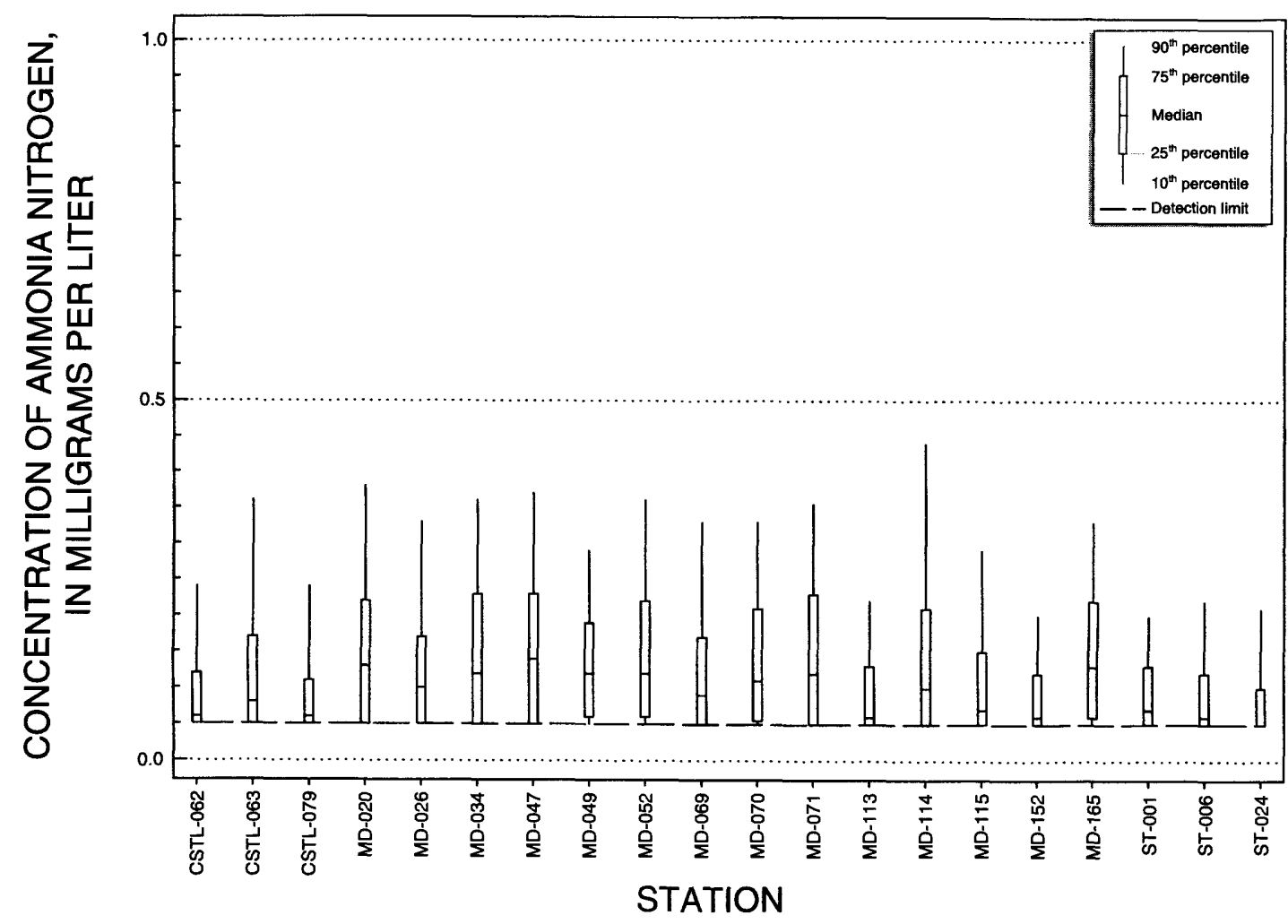

Figure 12. Ammonia nitrogen concentrations in the Cooper subunit, SANT study area, 1973-93.

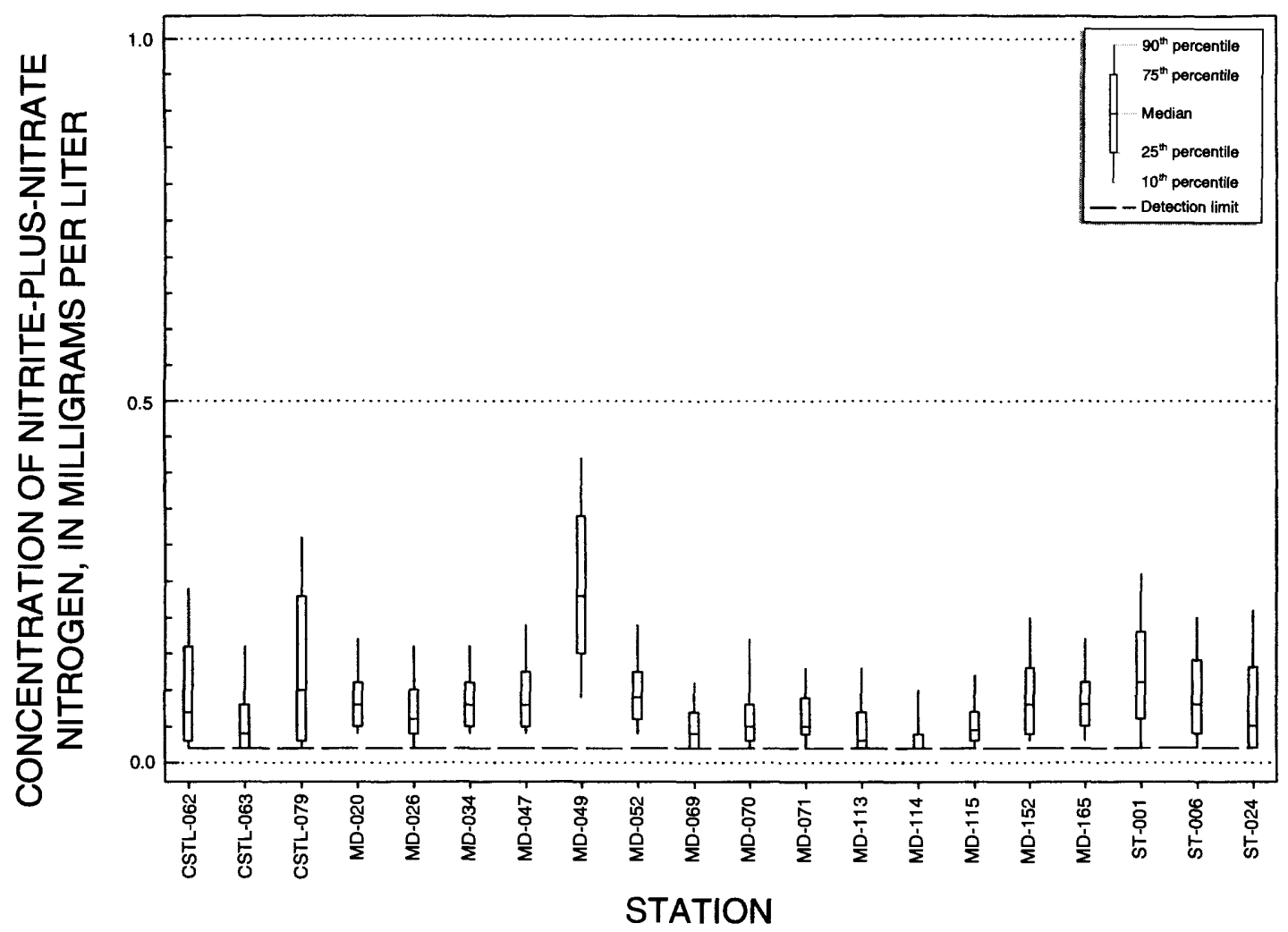

Figure 13. Nitrite-plus-nitrate nitrogen concentrations in the Cooper subunit, SANT study area, 1973-93. 


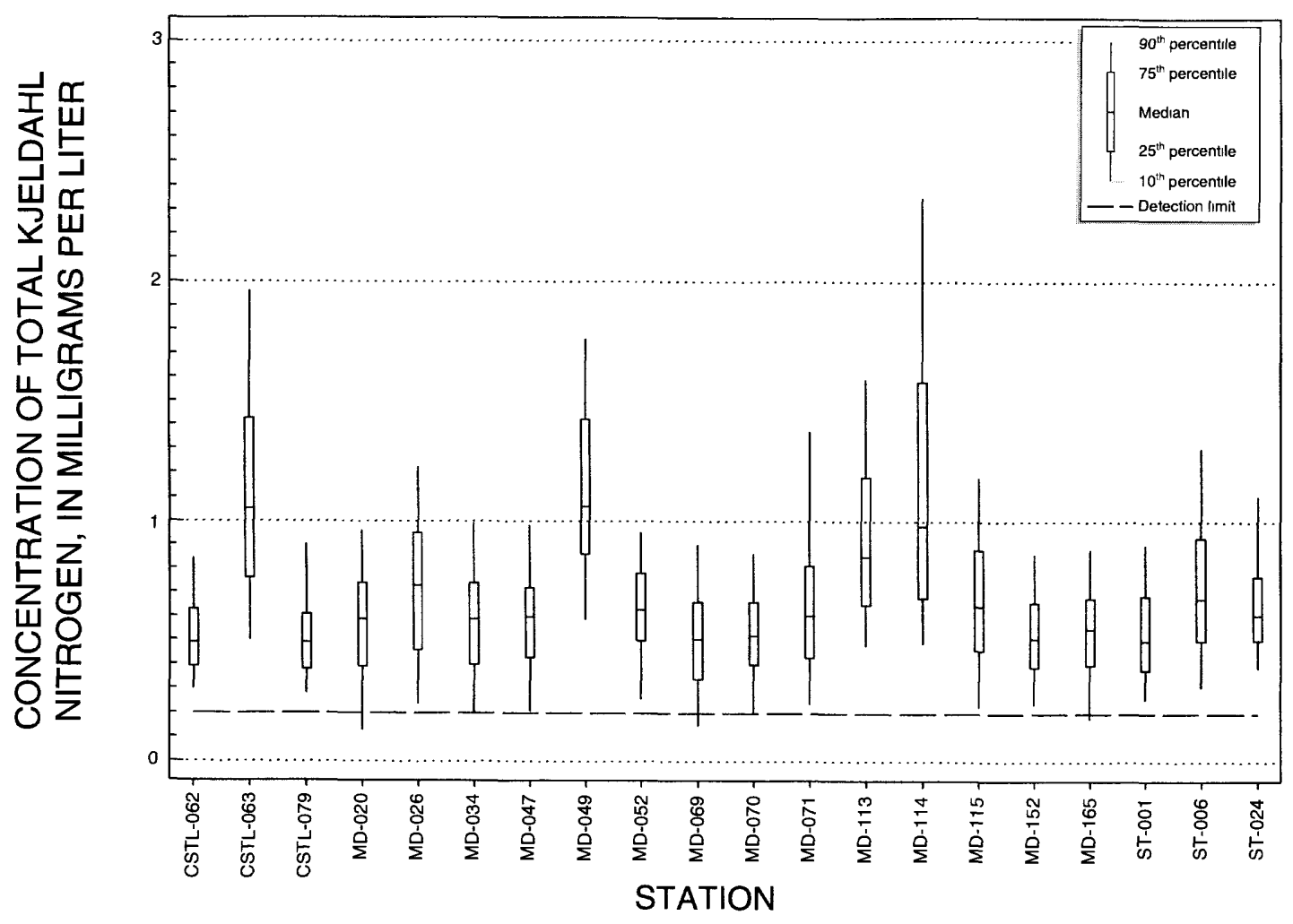

Figure 14. Total Kjeldahl nitrogen concentrations in the Cooper subunit, SANT study area, 1973-93.

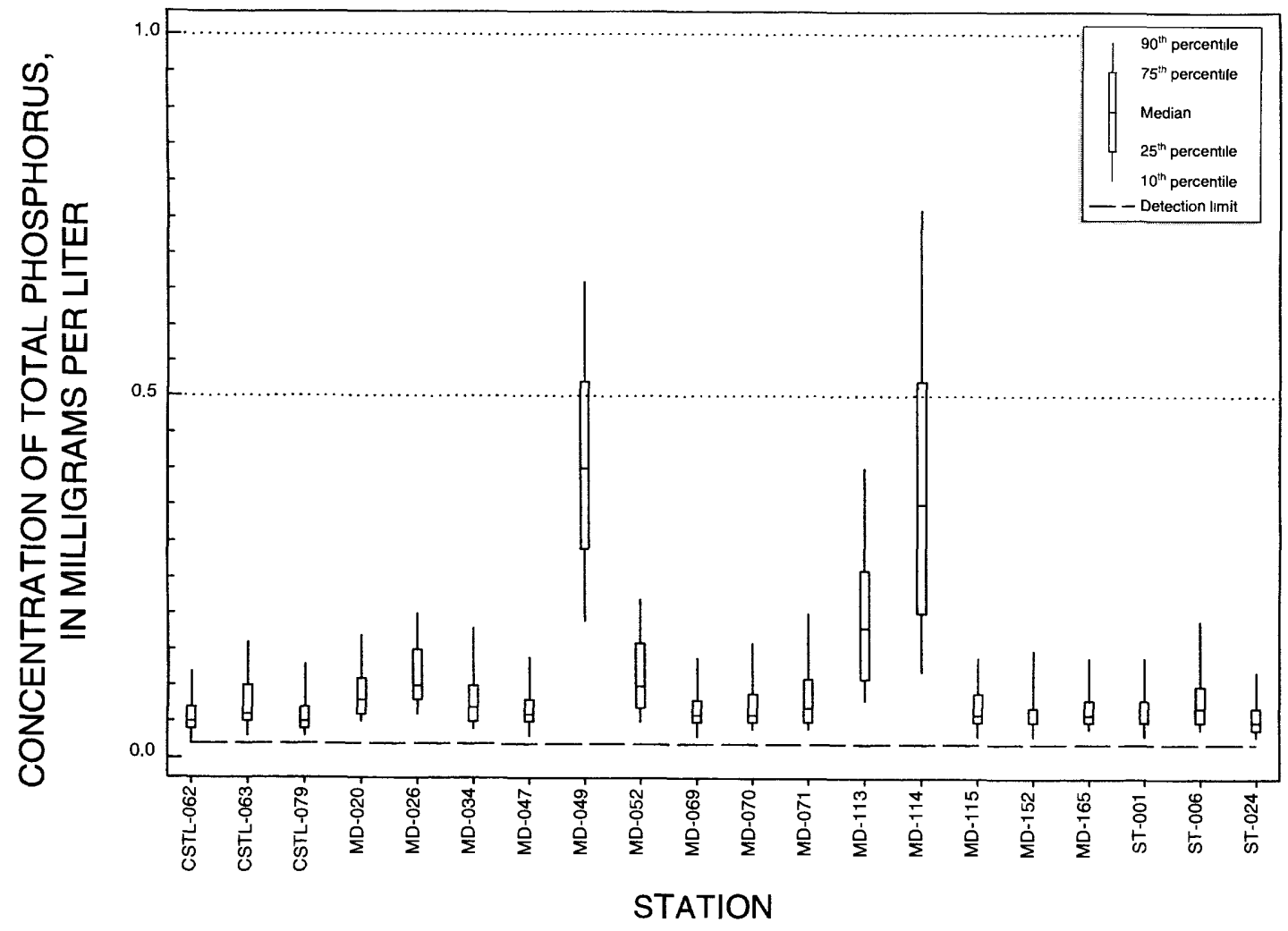

Figure 15. Total phosphorus concentrations in the Cooper subunit, SANT study area, 1973-93. 
Table 5. Temporal nutrient trends in the Cooper subunit, SANT study area, 1973-93

[Stream or lake in South Carolina; +, increasing trend; -, decreasing trend; n, no trend]

\begin{tabular}{|c|c|c|c|c|c|}
\hline $\begin{array}{l}\text { Station number } \\
\text { (fig. 2) }\end{array}$ & Stream or lake & $\begin{array}{c}\text { Ammonia } \\
\text { nitrogen }\end{array}$ & $\begin{array}{c}\text { Nitrite-plus- } \\
\text { nitrate } \\
\text { nitrogen }\end{array}$ & $\begin{array}{c}\text { Total } \\
\text { KjeldahI } \\
\text { nitrogen }\end{array}$ & $\begin{array}{c}\text { Total } \\
\text { phos- } \\
\text { phorus }\end{array}$ \\
\hline CSTL-062 & Tail Race Canal & $\mathrm{n}$ & - & $\bar{n}$ & - \\
\hline CSTL-063 & Wassamassaw Swamp & $\mathrm{n}$ & - & - & $\mathrm{n}$ \\
\hline CSTL-079 & Diversion canal & - & - & $\mathrm{n}$ & - \\
\hline MD-026 & Stono River & $\mathrm{n}$ & - & $\mathrm{n}$ & $\mathrm{n}$ \\
\hline MD-034 & Ashley River & $\mathrm{n}$ & - & $\mathrm{n}$ & $\mathrm{n}$ \\
\hline MD-047 & Town Creek & $\mathrm{n}$ & - & $\mathrm{n}$ & $\mathrm{n}$ \\
\hline MD-049 & Ashley River & $\mathrm{n}$ & + & $\mathrm{n}$ & $\mathrm{n}$ \\
\hline MD-071 & Shem Creek & - & - & $\mathrm{n}$ & - \\
\hline MD-113 & Goose Creek Reservoir & $\mathrm{n}$ & - & $\mathrm{n}$ & - \\
\hline MD-114 & Goose Creek & - & - & - & $\mathrm{n}$ \\
\hline MD-115 & Wando River & - & - & $\mathrm{n}$ & - \\
\hline MD-152 & Cooper River & $\mathrm{n}$ & - & $\mathrm{n}$ & $\mathrm{n}$ \\
\hline MD-165 & Charleston Harbor & $\mathrm{n}$ & - & $\mathrm{n}$ & $\mathrm{n}$ \\
\hline ST-001 & Santee River & $\mathrm{n}$ & - & $\mathrm{n}$ & $\mathrm{n}$ \\
\hline
\end{tabular}

Median total Kjeldahl nitrogen concentrations in the Edisto subunit ranged from 0.48 to $1.29 \mathrm{mg} / \mathrm{L}$ (fig. 18). The Pocotaligo River (MD-007) also had the highest median total Kjeldahl nitrogen concentration of $1.29 \mathrm{mg} / \mathrm{L}$, with a range of 0.09 to $22.00 \mathrm{mg} / \mathrm{L}$. Median concentrations at all other sites in the Edisto subunit were below $1.0 \mathrm{mg} / \mathrm{L}$.

Median total phosphorus concentrations in the Edisto subunit ranged from 0.05 to $0.25 \mathrm{mg} / \mathrm{L}$ (fig. 19). The Pocotaligo River (MD-007) had the highest median concentration $(0.25 \mathrm{mg} / \mathrm{L})$ with a range of 0.03 to $0.94 \mathrm{mg} / \mathrm{L}$ total phosphorus.
Statistically significant decreasing ammonia nitrogen trends were observed at 3 of the 14 stations in the Edisto subunit (table 6), including the Salkehatchie River (CSTL-028), the North Fork Edisto River (E-008), and the Edisto River (E-013). An increasing trend in ammonia nitrogen was observed in the Edisto River at station 02175000.

Temporal trends in nitrite-plus-nitrate nitrogen reflected significantly decreasing concentrations at five stations (table 6). Only one station indicated a significant increasing nitrite-plus-nitrate nitrogen trend, the North Fork Edisto River (E-008), possibly as a result of increased nitrification at upstream wastewater treatment facilities, and instream nitrification of ammonia. 


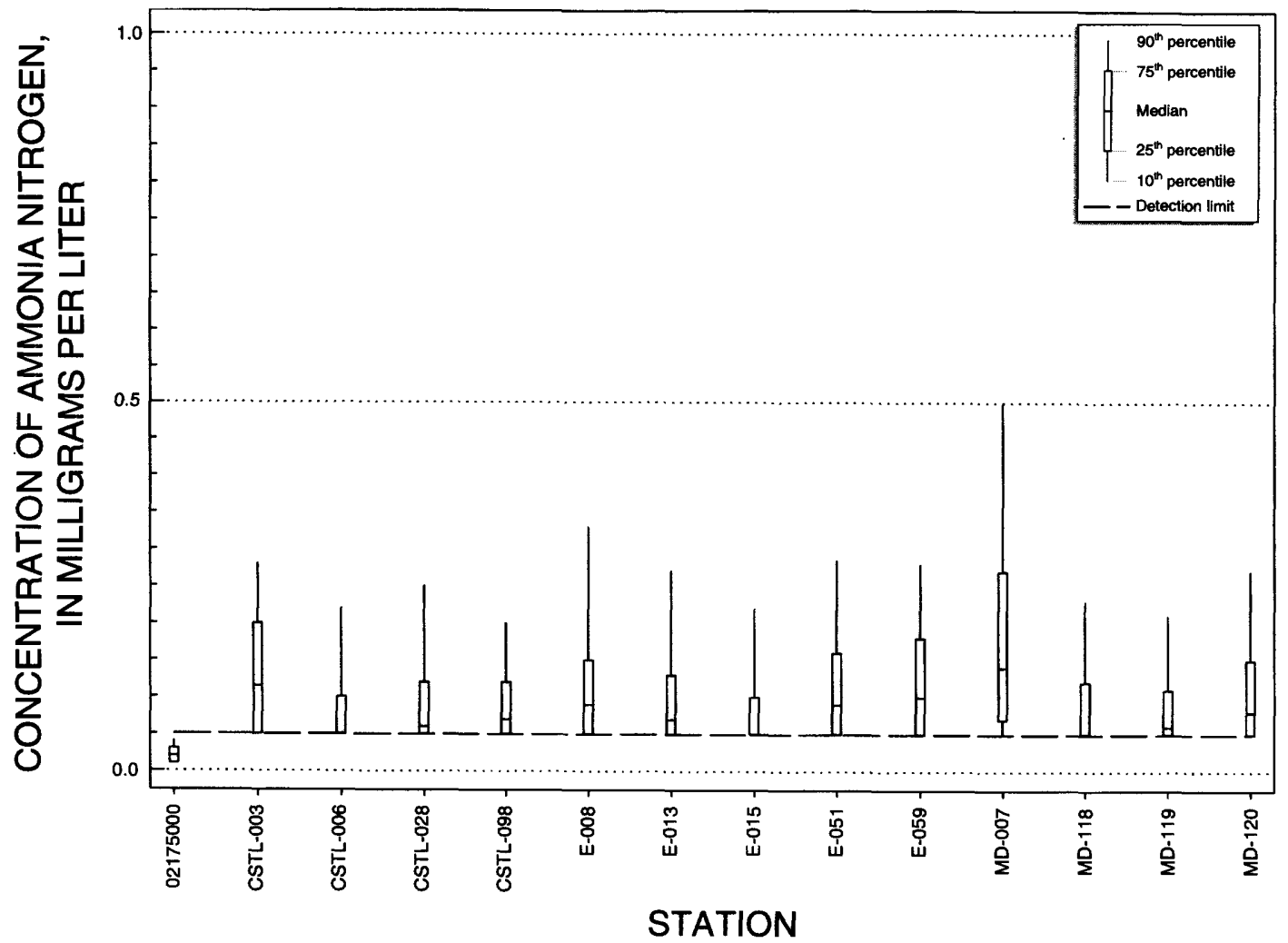

Figure 16. Ammonia nitrogen concentrations in the Edisto subunit, SANT study area, 1973-93.

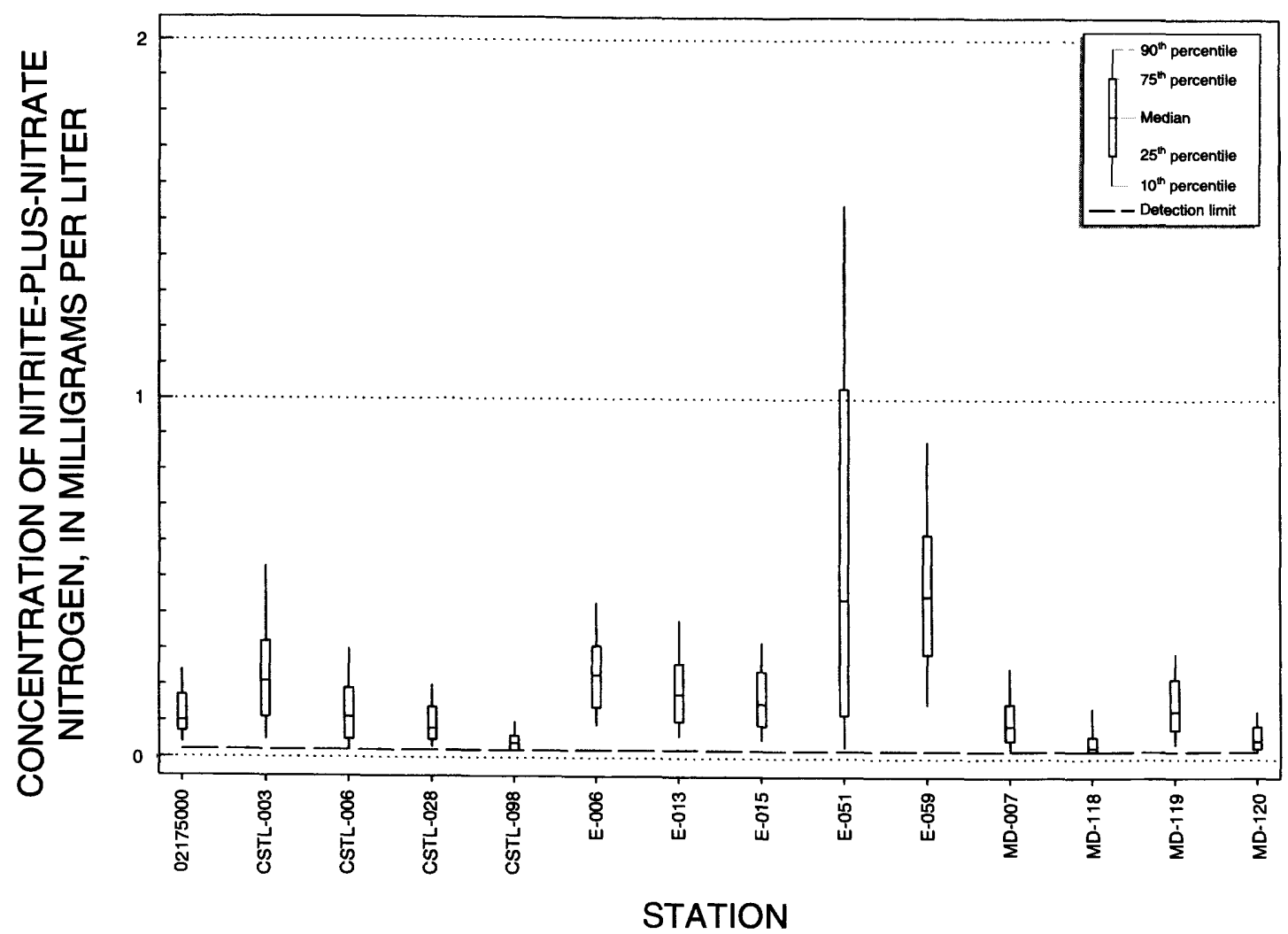

Figure 17. Nitrite-plus-nitrate nitrogen concentrations in the Edisto subunit, SANT study area, 1973-93. 


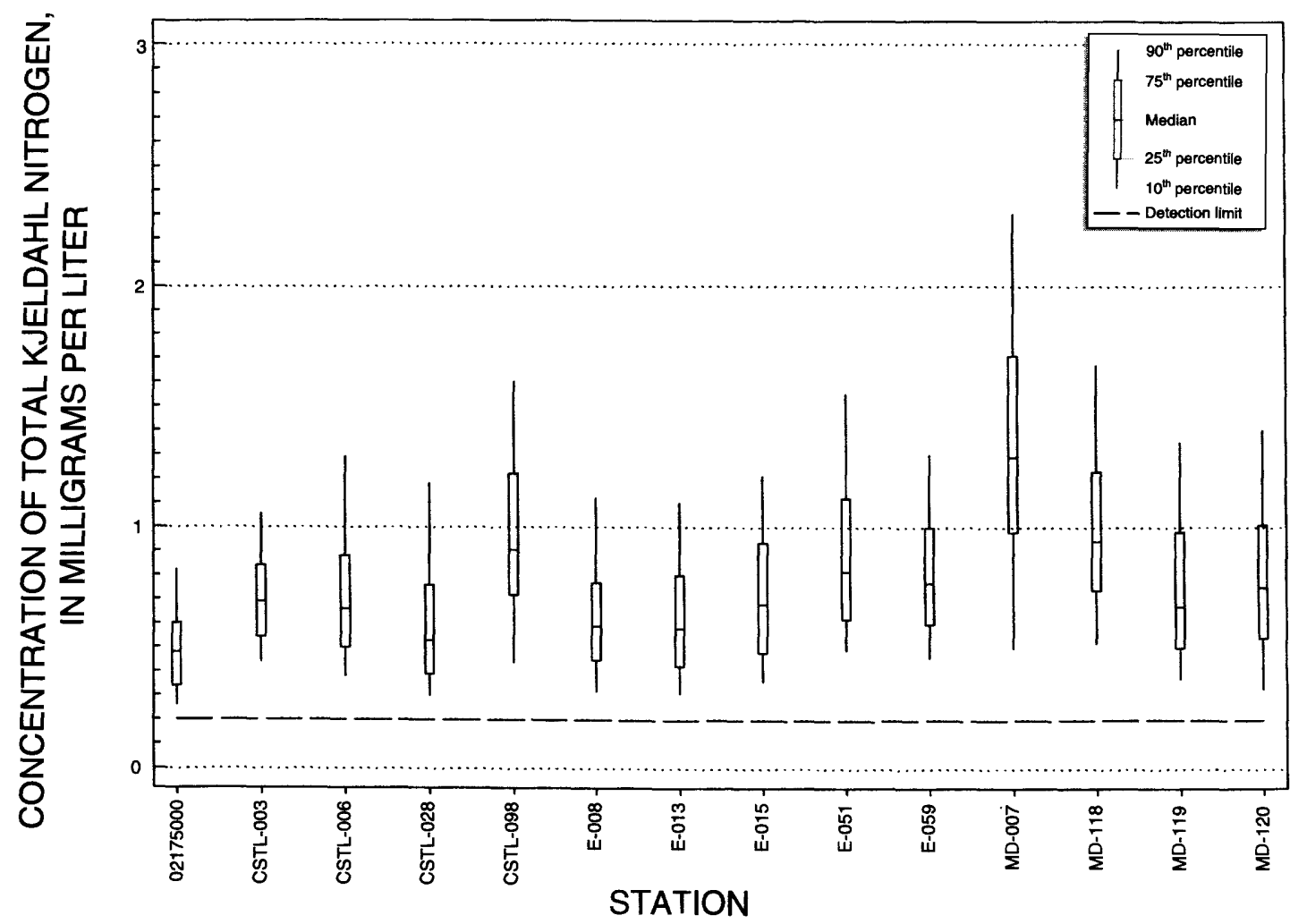

Figure 18. Total Kjeldahl nitrogen concentrations in the Edisto subunit, SANT study area, 1973-93.

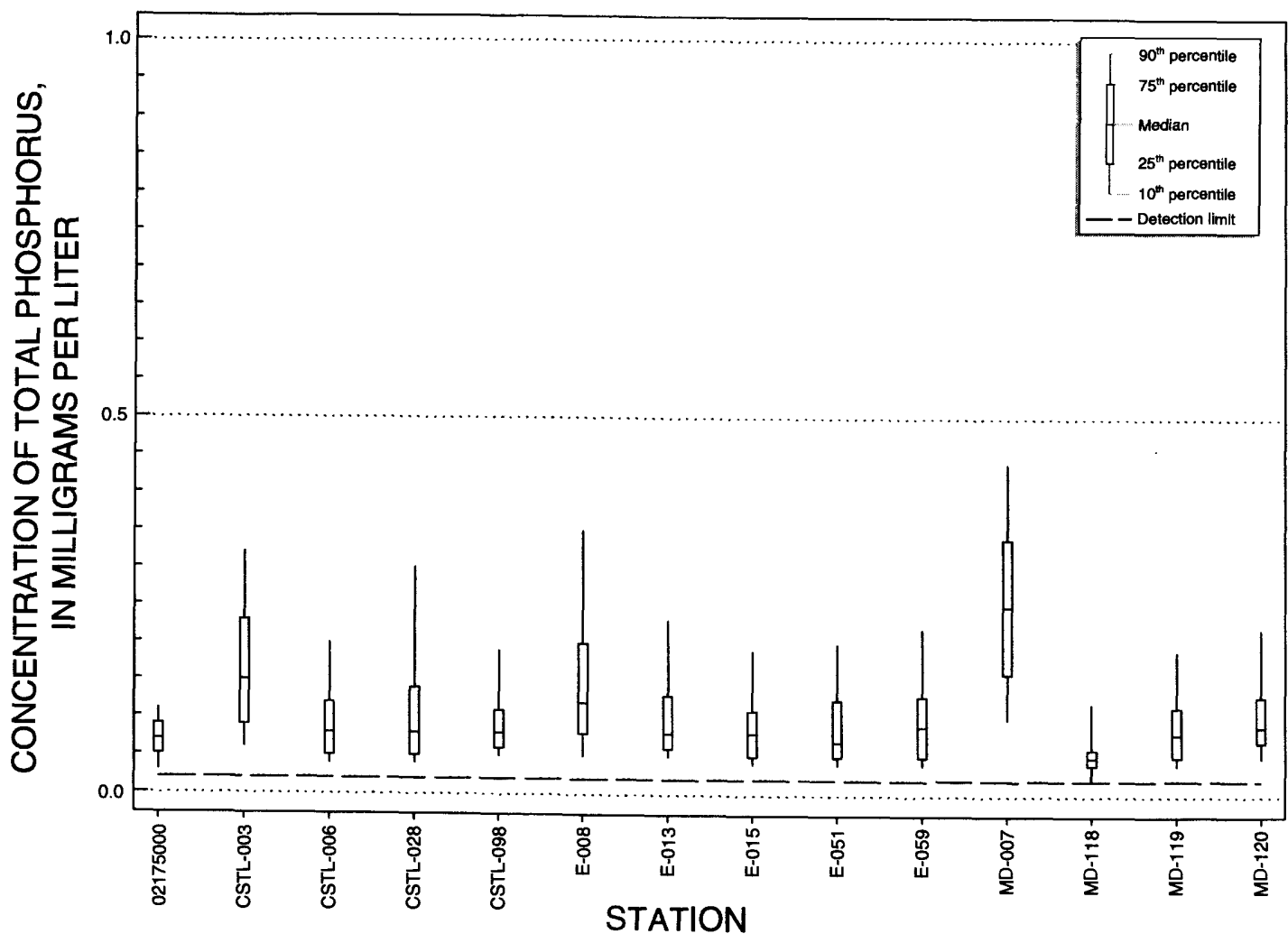

Figure 19. Total phosphorus concentrations in the Edisto subunit, SANT study area, 1973-93. 
Table 6. Temporal nutrient trends in the Edisto subunit, SANT study area, 1973-93

[Stream or lake in South Carolina; +, increasing trend; -, decreasing trend; $\mathbf{n}$, no trend]

\begin{tabular}{|c|c|c|c|c|c|}
\hline $\begin{array}{c}\text { Station } \\
\text { number } \\
\text { (flg. 2) }\end{array}$ & Stream or lake & $\begin{array}{c}\text { Ammonia } \\
\text { nitrogen }\end{array}$ & $\begin{array}{c}\text { Nitrite-plus- } \\
\text { nitrate } \\
\text { nitrogen }\end{array}$ & $\begin{array}{c}\text { Total } \\
\text { KjeidahI } \\
\text { nitrogen }\end{array}$ & $\begin{array}{l}\text { Total } \\
\text { phos- } \\
\text { phorus }\end{array}$ \\
\hline 02175000 & Edisto River & + & $\mathrm{n}$ & $\mathbf{n}$ & $\mathbf{n}$ \\
\hline CSTL-003 & Salkehatchie River & $\mathbf{n}$ & $\mathbf{n}$ & - & $\mathbf{n}$ \\
\hline CSTL-006 & Salkehatchie River & $\mathbf{n}$ & - & $\cdot$ & - \\
\hline CSTL-028 & Salkehatchie River & - & - & $\cdot$ & - \\
\hline CSTL-098 & Combahee River & $\mathbf{n}$ & - & - & $\mathbf{n}$ \\
\hline E-008 & North Fork Edisto River & - & + & - & - \\
\hline E-013 & Edisto River & - & $\mathbf{n}$ & - & $\mathbf{n}$ \\
\hline E-015 & Edisto River & $\mathbf{n}$ & $\mathbf{n}$ & n & $\mathbf{n}$ \\
\hline E-051 & Providence Swamp & $\mathbf{n}$ & $\mathbf{n}$ & $\mathbf{n}$ & $\mathbf{n}$ \\
\hline E-059 & Four Hole Swamp & $\mathbf{n}$ & $\mathbf{n}$ & - & $\mathbf{n}$ \\
\hline MD-007 & Pocotaligo River & $\mathbf{n}$ & $\mathbf{n}$ & n & $\mathbf{n}$ \\
\hline MD-118 & New River & $\mathbf{n}$ & - & - & - \\
\hline MD-119 & Edisto River & $\mathbf{n}$ & $\mathbf{n}$ & - & $\mathbf{n}$ \\
\hline MD-120 & Dawhoo River & $\mathbf{n}$ & - & $\mathbf{n}$ & $\mathbf{n}$ \\
\hline
\end{tabular}

Significantly decreasing trends in total Kjeldahl nitrogen concentrations were observed at nine of the stations in the Edisto subunit (table 6). There were no stations with significant increases in total Kjeldahl nitrogen.

Statistically significant decreases in total phosphorus concentrations were observed at 4 of the 14 stations (table 6). Stations with significant decreasing trends included the North Fork Edisto River (E-008), the New River (MD-118), and the Salkehatchie River (CSTL-028 and CSTL-006). These decreases may have resulted from changes in agricultural practices, a decrease in agricultural land use, or possibly from the phosphate detergent ban. There were no stations with significant increases in total phosphorus.

\section{Seasonality of Nutrient Concentrations}

Nutrient concentrations in water can vary seasonally as a result of external sources and internal processing. Seasonal fertilizer application may result in fluctuations in nutrient levels in receiving streams. Seasonal rains deposit nutrients from the atmosphere and produce runoff containing fertilizer, manure, and nutrient-carrying sediment. During winter months, bacterial processes can slow, resulting in decreased nitrification of ammonia nitrogen and lower concentrations of nitrite-plus-nitrate nitrogen, such as the pattern observed in the Salkehatchie River (fig. 20). Alternatively, the Cooper River (fig. 21) and Gills Creek (fig. 22) show higher median concentrations of nitriteplus-nitrate nitrogen in the winter months, which may result from reduced demand by phytoplankton and aquatic macrophytes. Total phosphorus varies seasonally as well, with lower concentrations observed in the summer months when algae and aquatic macrophyte uptake rates may be higher, as shown in the South Fork Catawba River (fig. 23).

In addition to using boxplots to show seasonal variability, the variance of the medians for each month for each parameter were assessed using the Wilcoxon rank-sum test, which corresponds to the Kruskal-Wallis test statistic for data sets with more than two classes. Stations in each subunit with significantly different monthly medians at alpha $=0.05$ are indicated in table 7. Nitrite-plus-nitrate nitrogen showed the greatest seasonality of the four parameters analyzed in each of the four subunits. 


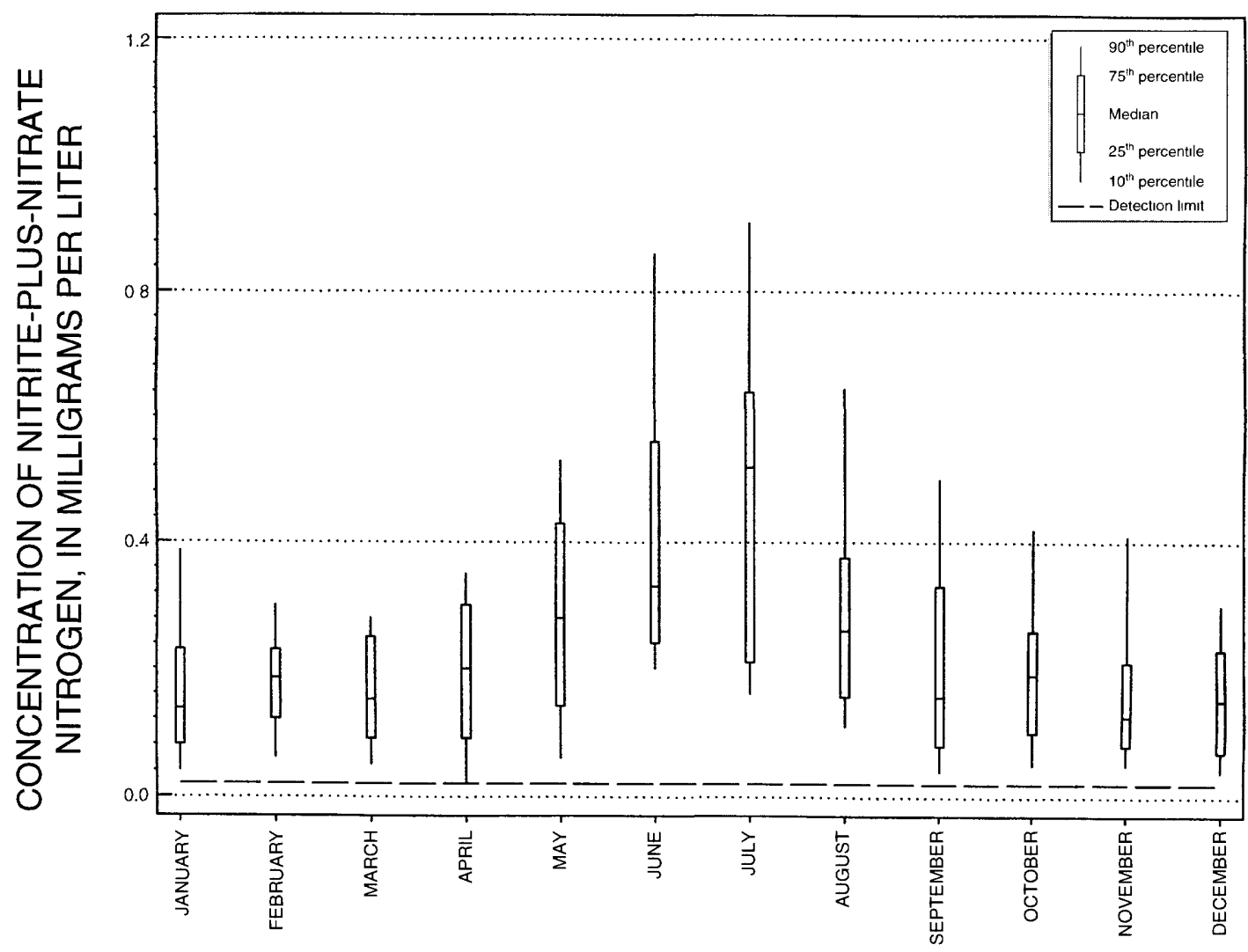

Figure 20. Monthly nitrite-plus-nitrate nitrogen concentrations at the Salkehatchie River at U.S. Route 278, SANT study area, 1973-93.

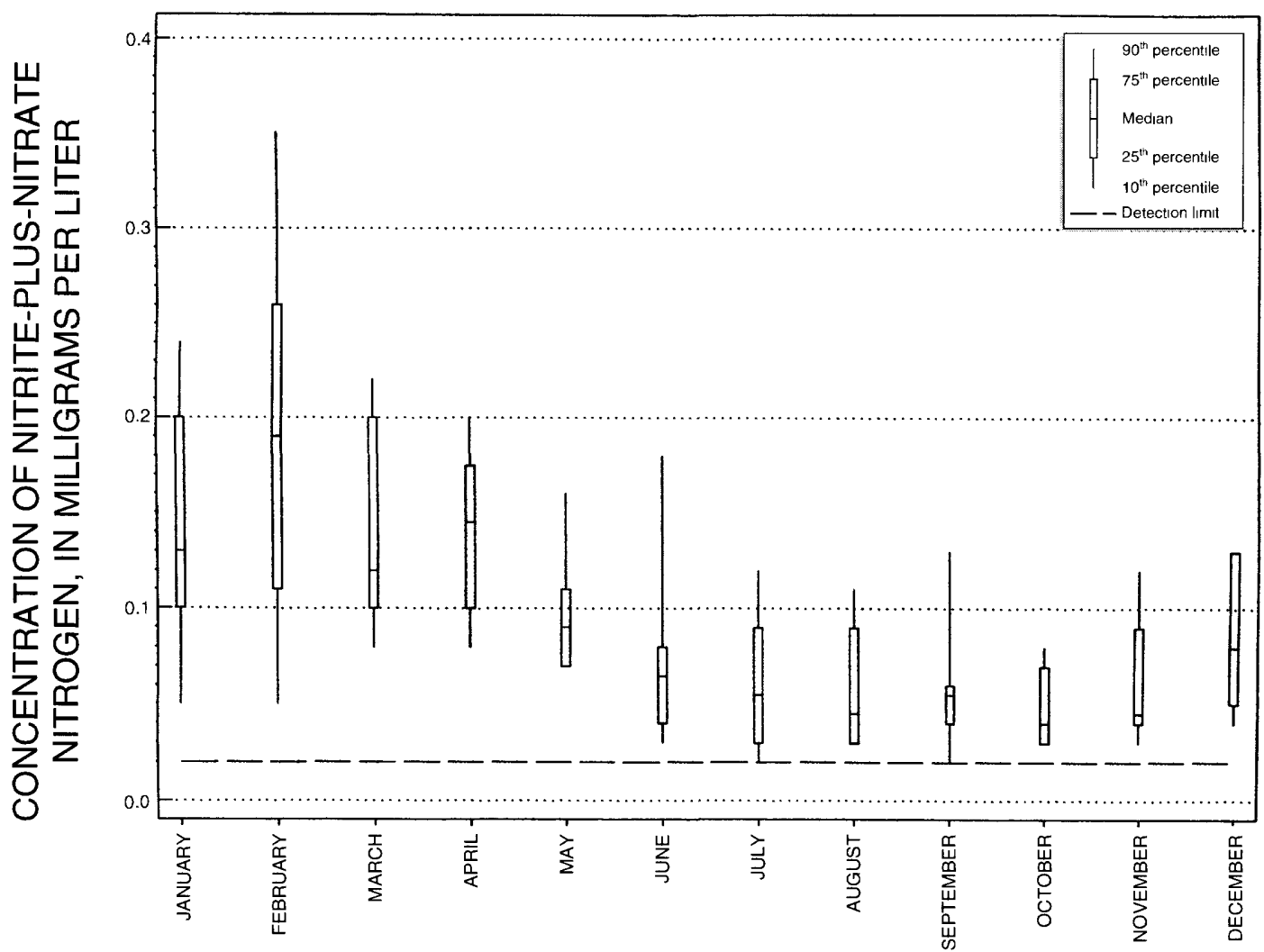

Figure 21. Monthly nitrite-plus-nitrate nitrogen concentrations at the Cooper River at S.C. Road S-08-503, SANT study area, 1973-93. 


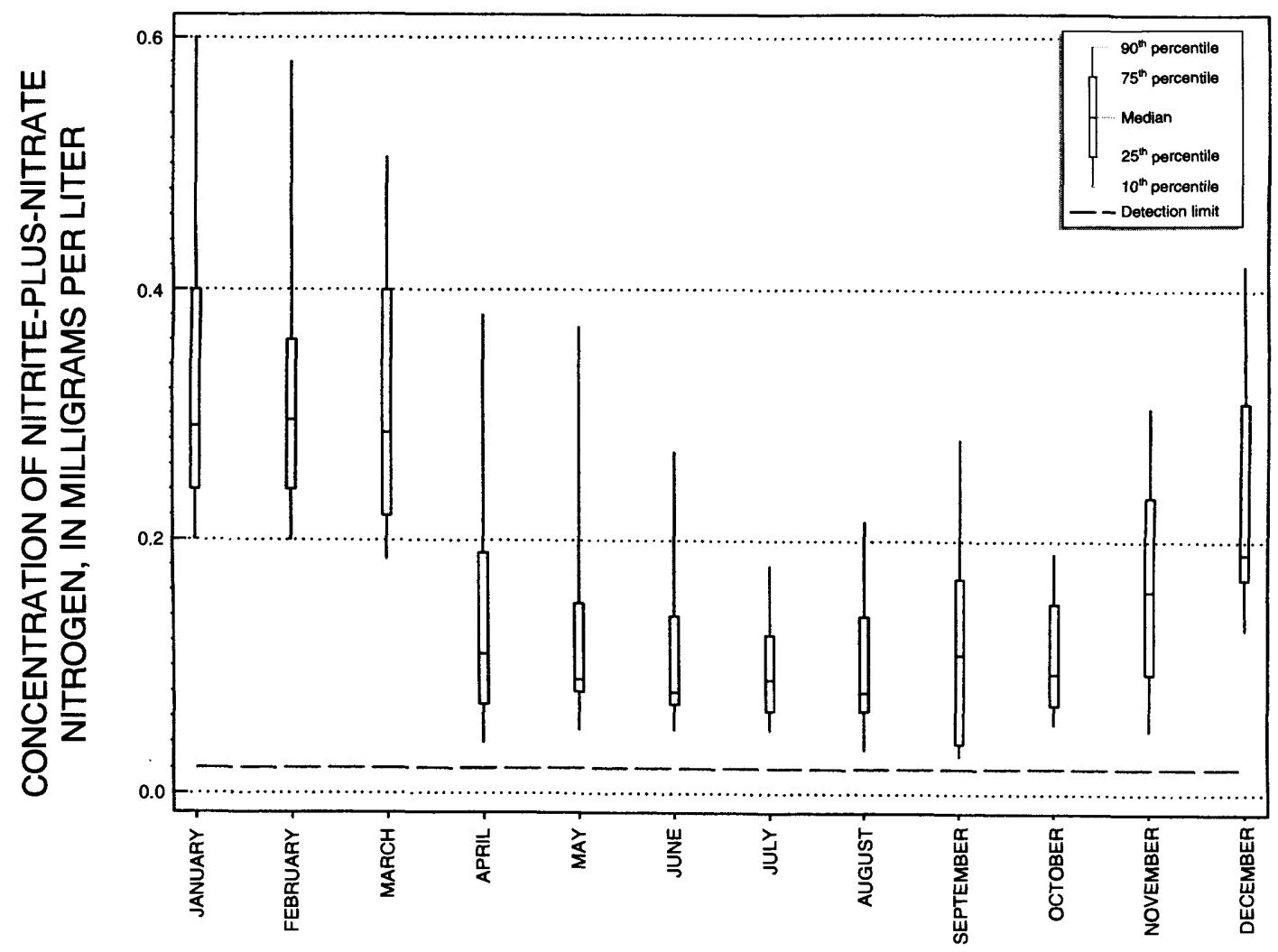

Figure 22. Monthly nitrite-plus-nitrate concentrations at the Gills Creek, Forest Acres, SANT study area, 1973-93.

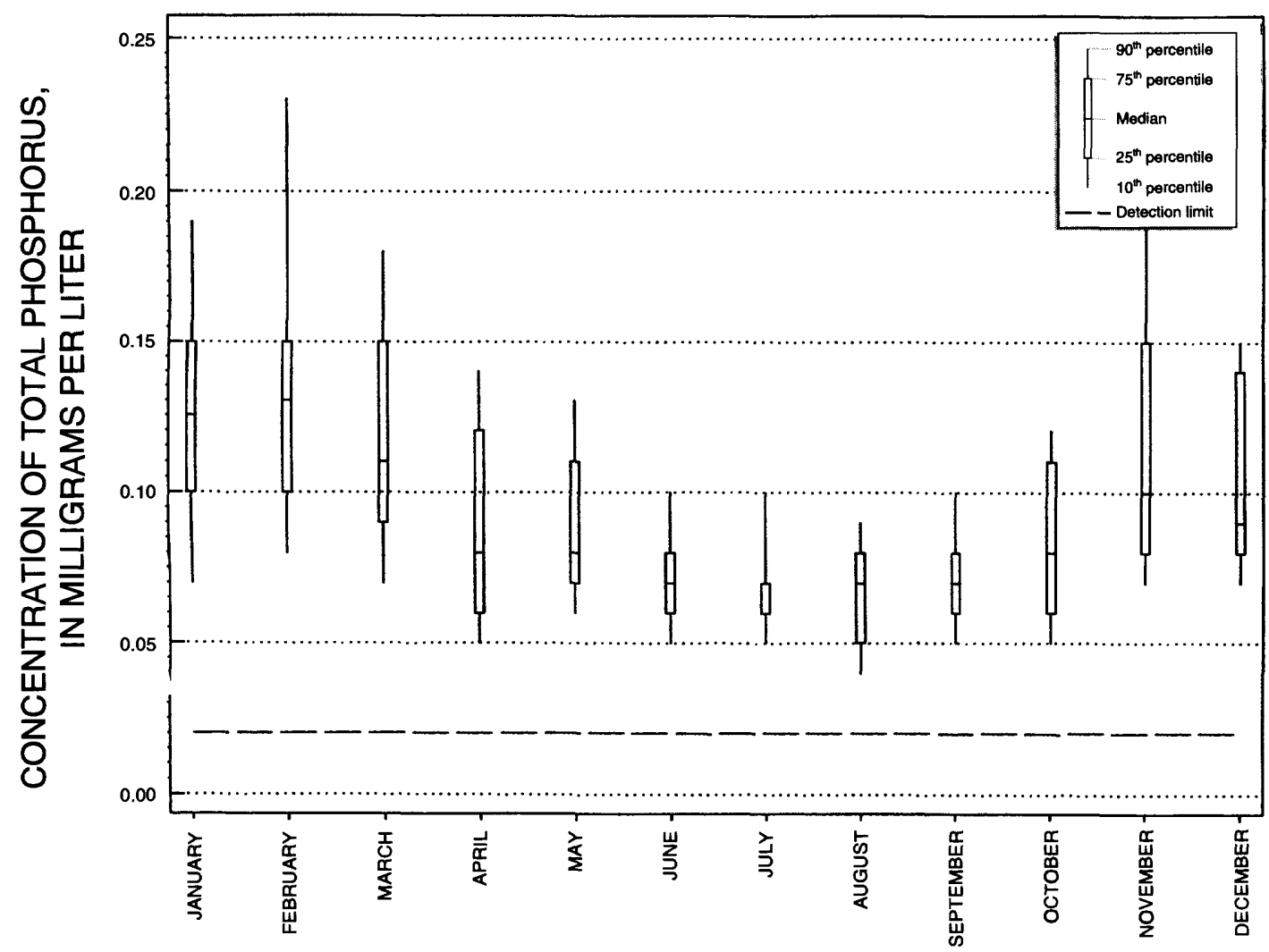

Figure 23. Monthly total phosphorus concentrations at the South Fork Catwba River, SANT study area, 1973-93. 
Table 7. Seasonal nutrient trends in the SANT study area, 1973-93

[Stream or lake in South Carolina except where indicated; +, significant seasonal trend; $n$, no significant seasonal trend]

\begin{tabular}{|c|c|c|c|c|c|}
\hline $\begin{array}{l}\text { Station number } \\
\text { (flg. 2) }\end{array}$ & Stream or lake & $\begin{array}{c}\text { Ammonia } \\
\text { nitrogen }\end{array}$ & $\begin{array}{c}\text { Nitrite-plus- } \\
\text { nitrate } \\
\text { nitrogen }\end{array}$ & $\begin{array}{c}\text { Total } \\
\text { KJeldahI } \\
\text { nltrogen }\end{array}$ & $\begin{array}{l}\text { Total } \\
\text { phos- } \\
\text { phorus }\end{array}$ \\
\hline \multicolumn{6}{|c|}{ Broad Subunit } \\
\hline A4400000 & Second Broad River, N.C. & + & + & $\mathbf{n}$ & $\mathbf{n}$ \\
\hline A6400000 & First Broad River, N.C. & $\mathbf{n}$ & + & + & + \\
\hline A8600000 & Buffalo Creek, N.C. & + & + & + & + \\
\hline B-008 & Tyger River & $\mathbf{n}$ & $\mathbf{n}$ & $\mathbf{n}$ & $\mathbf{n}$ \\
\hline B-021 & Fairforest Creek & + & $\mathbf{n}$ & $\mathbf{n}$ & + \\
\hline B-026 & North Pacolet River & $\mathbf{n}$ & + & $\mathbf{n}$ & $\mathbf{n}$ \\
\hline B-041 & Enoree River & + & $\mathbf{n}$ & $\mathbf{n}$ & + \\
\hline B-042 & Broad River & $\mathbf{n}$ & + & $\mathbf{n}$ & $\mathbf{n}$ \\
\hline B-044 & Broad River & $\mathbf{n}$ & + & $\mathbf{n}$ & $\mathbf{n}$ \\
\hline B-046 & Broad River & $\mathbf{n}$ & + & $\mathbf{n}$ & $\mathbf{n}$ \\
\hline B-048 & Pacolet River & $\mathbf{n}$ & + & $\mathbf{n}$ & $\mathbf{n}$ \\
\hline B-051 & Tyger River & $\mathbf{n}$ & + & $\mathbf{n}$ & $\mathbf{n}$ \\
\hline B-054 & Enoree River & $\mathbf{n}$ & + & $\mathbf{n}$ & $\mathbf{n}$ \\
\hline B-080 & Broad River & $\mathbf{n}$ & + & $\mathbf{n}$ & $\mathbf{n}$ \\
\hline B-148 & Middle Tyger River & $\mathrm{n}$ & + & $\mathbf{n}$ & $\mathbf{n}$ \\
\hline B-236 & Broad River & $\mathbf{n}$ & + & $\mathbf{n}$ & $\mathbf{n}$ \\
\hline BE-001 & Tributary to Enoree River & $\mathbf{n}$ & + & $\mathbf{n}$ & $\mathbf{n}$ \\
\hline C-001 & Gills Creek & $\mathbf{n}$ & + & + & + \\
\hline C-007 & Congaree River & $\mathbf{n}$ & + & $\mathrm{n}_{\mathrm{l}}$ & $\mathbf{n}$ \\
\hline C-008 & Congaree Creek & $\mathbf{n}$ & + & $+\therefore$ & $\mathbf{n}$ \\
\hline C-017 & Gills Creek & $\mathbf{n}$ & + & + & + \\
\hline S-007 & Saluda River & $\mathbf{n}$ & + & $\mathbf{n}$ & $\mathbf{n}$ \\
\hline S-013 & Reedy River & $\mathbf{n}$ & + & $\mathbf{n}$ & $\mathbf{n}$ \\
\hline S-018 & Reedy River & $\mathbf{n}$ & + & $\mathbf{n}$ & $\mathbf{n}$ \\
\hline S-021 & Reedy River & + & $\mathbf{n}$ & $\mathbf{n}$ & $\mathbf{n}$ \\
\hline S-034 & Little River & $\mathbf{n}$ & + & $\mathbf{n}$ & $\mathbf{n}$ \\
\hline S-042 & Bush River & $\mathbf{n}$ & + & $\mathbf{n}$ & + \\
\hline S-073 & Reedy River & $\mathbf{n}$ & + & $\mathbf{n}$ & $\mathbf{n}$ \\
\hline S-088 & North Saluda River & $\mathbf{n}$ & $\mathbf{n}$ & $\mathbf{n}$ & $\mathbf{n}$ \\
\hline S-123 & Little Saluda River & $\mathbf{n}$ & + & + & + \\
\hline S-125 & Saluda River & $\mathbf{n}$ & + & $\mathbf{n}$ & $\mathbf{n}$ \\
\hline S-131 & Lake Greenwood & + & + & + & $\mathbf{n}$ \\
\hline S-186 & Saluda River & + & + & $\mathrm{n}$ & $\mathbf{n}$ \\
\hline
\end{tabular}


Table 7. Seasonal nutrient trends in the SANT study area, 1973-93--Continued

[Stream or lake in South Carolina except where indicated; +, significant seasonal trend; $n$, no significant seasonal trend]

\begin{tabular}{|c|c|c|c|c|c|}
\hline $\begin{array}{l}\text { Station number } \\
\text { (flg. 2) }\end{array}$ & Stream or lake & $\begin{array}{c}\text { Ammonla } \\
\text { nitrogen }\end{array}$ & $\begin{array}{c}\text { Nitrite-plus- } \\
\text { nitrate } \\
\text { nitrogen }\end{array}$ & $\begin{array}{c}\text { Total } \\
\text { Kjeldahl } \\
\text { nitrogen }\end{array}$ & $\begin{array}{c}\text { Total } \\
\text { phos- } \\
\text { phorus }\end{array}$ \\
\hline S-204 & Lake Murray & $\mathrm{n}$ & + & $\bar{n}$ & $\mathrm{n}$ \\
\hline S-223 & Lake Murray & $\mathbf{n}$ & + & $\mathrm{n}$ & + \\
\hline S-250 & Saluda River & $\mathbf{n}$ & + & + & $\mathrm{n}$ \\
\hline S-273 & Lake Murray & $\mathrm{n}$ & + & $\mathrm{n}$ & $\mathrm{n}$ \\
\hline S-274 & Lake Murray & $\mathbf{n}$ & + & $\mathrm{n}$ & $\mathrm{n}$ \\
\hline S-279 & Lake Murray & + & + & $\mathbf{n}$ & + \\
\hline S-280 & Lake Murray & $\mathrm{n}$ & + & $\mathbf{n}$ & $\mathrm{n}$ \\
\hline
\end{tabular}

$\begin{array}{ll}\text { C1000000 } & \text { Linville River, N.C. } \\ \text { C2030000 } & \text { Lake Rhodiss, N.C. } \\ \text { C3900000 } & \text { Catawba River, N.C. } \\ \text { C4220000 } & \text { Catawba River, N.C. } \\ \text { C7000000 } & \text { South Fork Catawba River, N.C. } \\ \text { C7400000 } & \text { Catawba Creek } \\ \text { C8660000 } & \text { Crowders Creek } \\ \text { C9790000 } & \text { Sugar Creek } \\ \text { CW-016 } & \text { Catawba River } \\ \text { CW-023 } & \text { Crowders Creek } \\ \text { CW-029 } & \text { Fishing Branch } \\ \text { CW-041 } & \text { Catawba River } \\ \text { CW-197 } & \text { Lake Wylie } \\ \text { CW-198 } & \text { Lake Wylie } \\ \text { CW-201 } & \text { Lake Wylie } \\ \text { CW-206 } & \text { Wateree River } \\ & \end{array}$

Catawba Subunit

$\begin{array}{ll}\text { CSTL-062 } & \text { Tail Race Canal } \\ \text { CSTL-063 } & \text { Wassamassaw Swamp } \\ \text { CSTL-079 } & \text { Diversion canal } \\ \text { MD-020 } & \text { Wappoo Creek } \\ \text { MD-026 } & \text { Stono River } \\ \text { MD-034 } & \text { Ashley River } \\ \text { MD-047 } & \text { Town Creek } \\ \text { MD-049 } & \text { Ashley River } \\ \text { MD-052 } & \text { Ashley River }\end{array}$

Cooper Subunit 
Table 7. Seasonal nutrient trends in the SANT study area, 1973-93--Continued

[Stream or lake in South Carolina except where indicated; +, significant seasonal trend; $n$, no significant seasonal trend]

\begin{tabular}{|c|c|c|c|c|c|}
\hline $\begin{array}{l}\text { Station number } \\
\text { (fig. 2) }\end{array}$ & Stream or lake & $\begin{array}{c}\text { Ammonia } \\
\text { nitrogen }\end{array}$ & $\begin{array}{c}\text { Nitrite-pius- } \\
\text { nitrate } \\
\text { nitrogen }\end{array}$ & $\begin{array}{c}\text { Total } \\
\text { Kjeidahi } \\
\text { nitrogen }\end{array}$ & $\begin{array}{c}\text { Total } \\
\text { phos- } \\
\text { phorus }\end{array}$ \\
\hline MD-069 & Intracoastal Waterway & $\mathrm{n}$ & $\mathrm{n}$ & + & $\bar{n}$ \\
\hline MD-070 & Intracoastal Waterway & $\mathrm{n}$ & $\mathbf{n}$ & $\mathbf{n}$ & $\mathbf{n}$ \\
\hline MD-071 & Shem Creek & $\mathbf{n}$ & $\mathbf{n}$ & + & $\mathbf{n}$ \\
\hline MD-113 & Goose Creek Reservoir & $\mathrm{n}$ & + & + & + \\
\hline MD-114 & Goose Creek & + & $\mathbf{n}$ & + & $\mathbf{n}$ \\
\hline MD-115 & Wando River & $\mathrm{n}$ & + & + & $\mathbf{n}$ \\
\hline MD-152 & Cooper River & $\mathrm{n}$ & + & $\mathbf{n}$ & $\mathbf{n}$ \\
\hline MD-165 & Charleston Harbor & $\mathrm{n}$ & + & $\mathbf{n}$ & $\mathbf{n}$ \\
\hline ST-001 & Santee River & $\mathrm{n}$ & + & $\mathbf{n}$ & $\mathbf{n}$ \\
\hline ST-006 & South Santee River & $\mathrm{n}$ & + & $\mathrm{n}$ & $\mathbf{n}$ \\
\hline \multirow[t]{2}{*}{ ST-024 } & Lake Marion & $\mathrm{n}$ & + & $\mathbf{n}$ & $\mathbf{n}$ \\
\hline & & Edisto Subunit & & & \\
\hline 02175000 & Edisto River & + & $\mathbf{n}$ & $\mathbf{n}$ & + \\
\hline CSTL-003 & Salkehatchie River & $\mathrm{n}$ & + & + & + \\
\hline CSTL-006 & Salkehatchie River & n & + & $\mathbf{n}$ & + \\
\hline CSTL-028 & Salkehatchie River & n & + & + & + \\
\hline CSTL-098 & Combahee River & $\mathrm{n}$ & + & $\mathrm{n}$ & $\mathbf{n}$ \\
\hline E-008 & North Fork Edisto River & $\mathrm{n}$ & $\mathbf{n}$ & $\mathbf{n}$ & $\mathbf{n}$ \\
\hline E-013 & Edisto River & $\mathbf{n}$ & + & $\mathrm{n}$ & + \\
\hline E-015 & Edisto River & $\mathrm{n}$ & + & $\mathrm{n}$ & + \\
\hline E-051 & Providence Swamp & + & + & + & + \\
\hline E-059 & Four Hole Swamp & + & + & + & + \\
\hline MD-007 & Pocotaligo River & $\mathbf{n}$ & $\mathbf{n}$ & + & + \\
\hline MD-118 & New River & $\mathrm{n}$ & $\mathbf{n}$ & $\mathbf{n}$ & $\mathbf{n}$ \\
\hline MD-119 & Edisto River & + & + & $\mathrm{n}$ & + \\
\hline MD-120 & Dawhoo River & $\mathbf{n}$ & + & + & $\mathrm{n}$ \\
\hline
\end{tabular}




\section{Study Area Nutrient Loads}

Nutrients enter surface waters from various sources. Nonpoint sources that can contribute to surface-water nutrient loads include atmospheric deposition of nitrogen and phosphorus species, mineral weathering, and runoff from agricultural and urban areas. Point-source discharges from wastewater-treatment plants and mineral mining can also contribute to nutrient loads in surface waters. Streams dominated by nonpoint-source runoff tend to have constant or increasing concentrations of nutrients as streamflow increases, such as during a storm event, while streams dominated by point sources generally show decreasing concentrations with increases in stream flow due to dilution.

\section{Nonpoint Sources}

The NADP/NTN (1995) provides data from measurements of wet deposition of ammonia nitrogen and nitrate nitrogen. Data from four NADP/NTN stations were used to calculate atmospheric input of ammonia nitrogen and nitrate nitrogen for the SANT study area: the Piedmont Research Station (NC34) and Mount Mitchell (NC45) in North Carolina, and the Santee National Wildlife Refuge (SC06) and Clemson (SC18) in South Carolina. Annual average deposition data from these four stations were used to calculate the distance-weighted average wet deposition for the study area. The annual NADP data were assessed for completeness, using criteria established by the NADP Technical Committee. Because almost all orthophosphate concentrations are below the analytical detection limit, deposition rates for phosphorus are not included in the data set.

Using methods described by Sisterson (1990), estimates of dry atmospheric nitrogen deposition were made using NADP/NTN data from 1982-93. Separate calculations were made for urban and nonurban areas. Urban and nonurban areas were determined using 1970 USGS Land Use Land Cover digital data. Annual average deposition estimates for the SANT study area are listed in table 8. While urban land use accounts for only 7 percent of the SANT study area, the average annual deposition of ammonia nitrogen and nitrate nitrogen in urban areas accounts for approximately 20 percent of the study area total. This is because wet deposition rates of nitrogen species are approximately 1.75 times higher and dry deposition rates are approximately 5.0 times higher in urban areas than non-urban areas (Sisterson, 1990). Droplet deposition was not calculated because most of the SANT study area is below an elevation of $2,000 \mathrm{ft}$, and fog is observed less than 40 percent of the time on an annual basis.

Table 8. Annual average atmospheric deposition of ammonia and nitrate nitrogen in the SANT study area, 1982-1993

[Units in tons per year]

\begin{tabular}{cccccc}
\hline Parameter & $\begin{array}{c}\text { Urban } \\
\text { wet }\end{array}$ & $\begin{array}{c}\text { Urban } \\
\text { dry }\end{array}$ & $\begin{array}{c}\text { Non- } \\
\text { urban } \\
\text { wot }\end{array}$ & $\begin{array}{c}\text { Non- } \\
\text { urban } \\
\text { dry }\end{array}$ & $\begin{array}{c}\text { Study } \\
\text { area } \\
\text { total }\end{array}$ \\
\hline $\begin{array}{c}\text { Ammonia } \\
\text { nitrogen }\end{array}$ & 1,650 & 4,360 & 12,560 & 11,590 & 30,160 \\
$\begin{array}{c}\text { Nitrate } \\
\text { nitrogen }\end{array}$ & 8,440 & 22,260 & 64,080 & 59,150 & 153,930 \\
\hline
\end{tabular}

Agricultural practices also contribute to nonpoint sources of nutrients. A primary nonpoint source of nitrogen and phosphorus is commercial fertilizer (Puckett, 1995). Increases in fertilizer use can lead to increases in runoff of nutrients. In addition, animal manure is a nonpoint source of nutrients. Databases containing nitrogen and phosphorus loads from manure (Richard Alexander, U.S. Geological Survey, written commun., September 16, 1992) and fertilizer (U.S. Environmental Protection Agency, 1990) were used to estimate application by county. For those counties that lay partially within the study area, drainage basins were delineated and the fraction of the county within the study area was used to calculate estimated applications using the assumption of equal distribution of agricultural land within the county.

The manure database represents estimates of the nutrient content of daily wastes produced per 1,000 pounds of animal weight for 1992 for each county. County fertilizer use was calculated by multiplying the 1987 Census of Agriculture annual state use by the ratio of county fertilizer expenditures to state fertilizer expenditures. Estimated fertilizer application rates for the study area ranged from about 0.37 tons of nitrogen per square mile and 0.15 tons of phosphorus per square mile in Jasper County, S.C., to 6.3 tons of nitrogen per square mile and 2.6 tons of phosphorus per square mile in Lee County, S.C. (figs. 24 and 25). The estimated fertilizer and manure nitrogen and phosphorus application by county, in tons per year, calculated for only that part of the county that lies within the study area are listed in tables 9 and 10. 


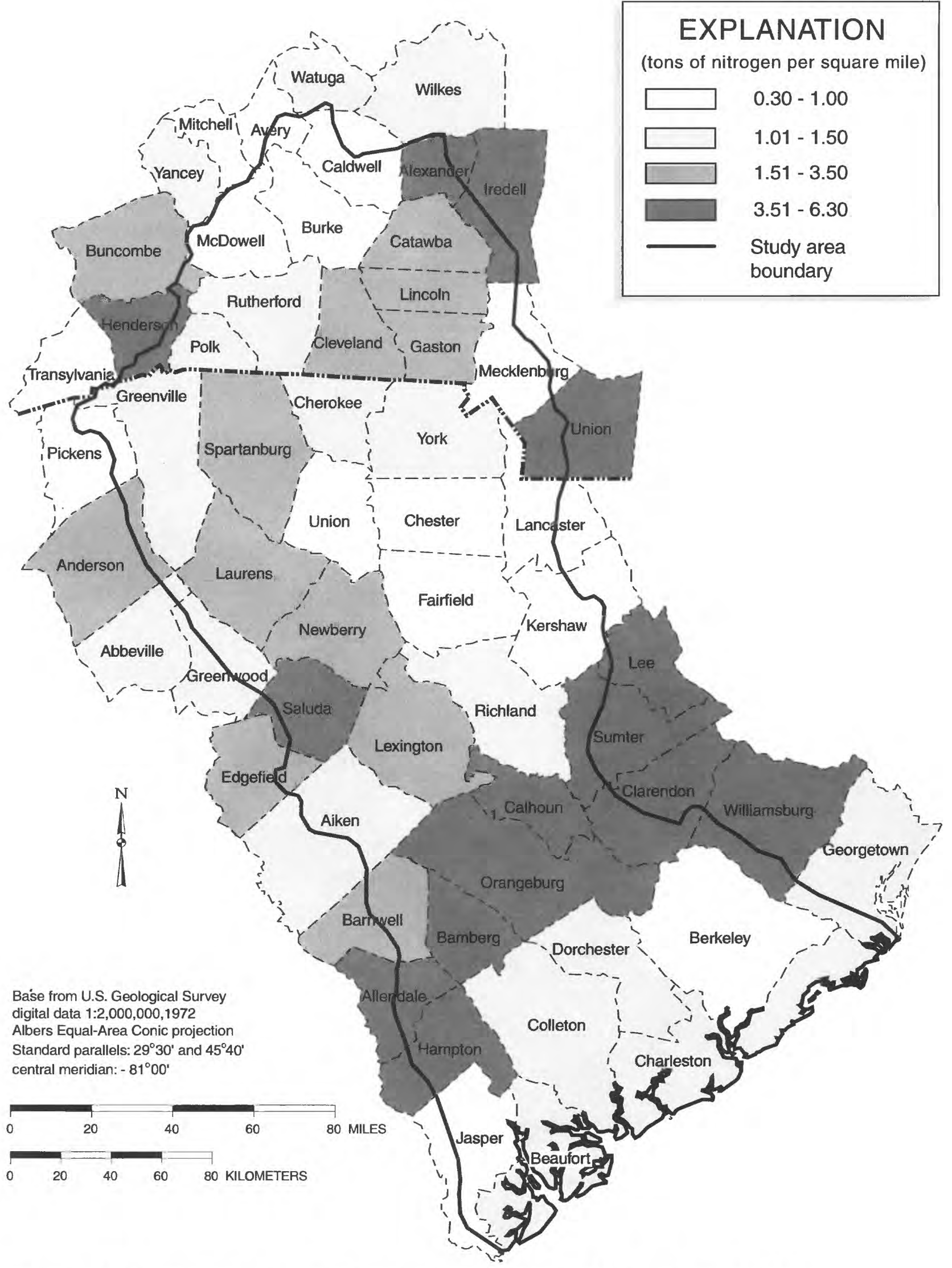

Figure 24. Nitrogen application rates from fertilizer by county, SANT study area, 1987. 


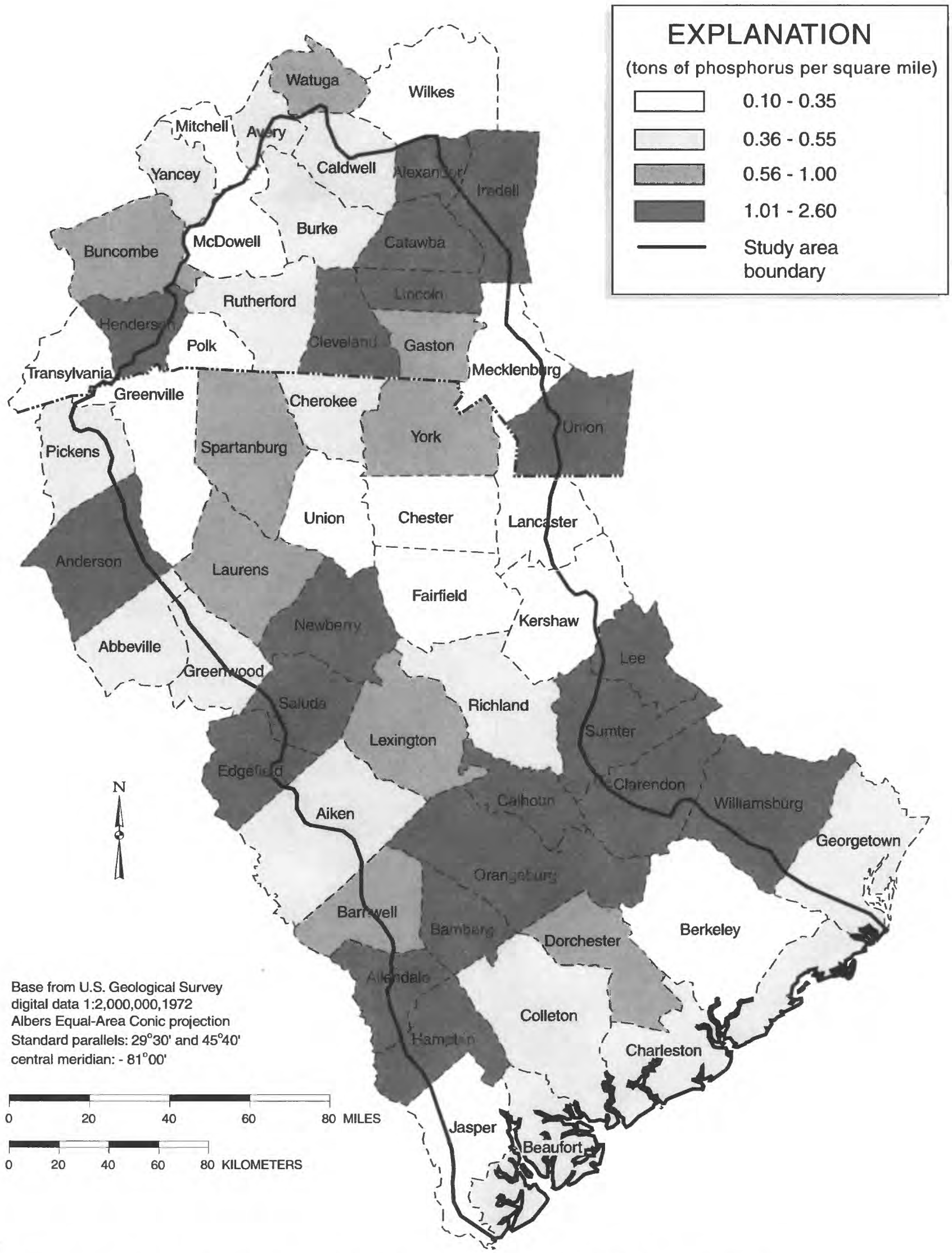

Figure 25. Phosphorus application rates from fertilizer by county, SANT study area, 1987. 
Table 9. Fertilizer and manure nitrogen application rates in the SANT study area by county, 1987 (fertilizer), 1992 (manure)

[County in South Carolina except where indicated; units in tons per year]

\begin{tabular}{|c|c|c|c|}
\hline County & Fertilizer nitrogen & Manure nitrogen & Total nitrogen \\
\hline Orangeburg & 5,410 & 2,757 & 8,167 \\
\hline Lexington & 1,396 & 3,706 & 5,102 \\
\hline Newberry & 1,637 & 2,059 & 3,696 \\
\hline Union, N.C. & 942 & 2,594 & 3,536 \\
\hline Saluda & 1,549 & 1,965 & 3,514 \\
\hline Cleveland, N.C. & 1,317 & 1,554 & 2,871 \\
\hline Spartanburg & 1,718 & 1,096 & 2,814 \\
\hline Alexander, N.C. & 715 & 1,861 & 2,576 \\
\hline Laurens & 1,130 & 1,368 & 2,498 \\
\hline Bamberg & 1,701 & 633 & 2,334 \\
\hline Calhoun & 1,682 & 575 & 2,257 \\
\hline York & 957 & 1,218 & 2,175 \\
\hline Lincoln, N.C. & 1,062 & 1,073 & 2,135 \\
\hline Colleton & 1,326 & 632 & 1,958 \\
\hline Catawba, N.C. & 986 & 949 & 1,935 \\
\hline Hampton & 1,692 & 181 & 1,873 \\
\hline Clarendon & 1,492 & 334 & 1,826 \\
\hline Greenville & 1,077 & 745 & 1,822 \\
\hline Aiken & 552 & 1,059 & 1,611 \\
\hline Iredell, N.C. & 611 & 813 & 1,424 \\
\hline Burke, N.C. & 442 & 920 & 1,362 \\
\hline Sumter & 910 & 370 & 1,280 \\
\hline Dorchester & 855 & 405 & 1,260 \\
\hline Rutherford, N.C. & 627 & 585 & 1,212 \\
\hline Charleston & 1,054 & 71 & 1,125 \\
\hline Gaston, N.C. & 547 & 559 & 1,106 \\
\hline Richland & 776 & 311 & 1,087 \\
\hline Chester & 376 & 705 & 1,081 \\
\hline Cherokee & 467 & 550 & 1,017 \\
\hline Williamsburg & 772 & 125 & 897 \\
\hline
\end{tabular}


Table 9. Fertilizer and manure nitrogen application rates in the SANT study area by county, 1987 (fertilizer), 1992 (manure)--Continued

[County in South Carolina except where indicated; units in tons per year]

\begin{tabular}{|c|c|c|c|}
\hline County & Fertilizer nitrogen & Manure nitrogen & Total nitrogen \\
\hline Berkeley & 642 & 254 & 896 \\
\hline Barnwell & 628 & 232 & 860 \\
\hline Allendale & 737 & 51 & 788 \\
\hline Caldwell, N.C. & 282 & 459 & 741 \\
\hline Union & 357 & 381 & 738 \\
\hline Beaufort & 652 & 69 & 721 \\
\hline Lancaster & 305 & 392 & 697 \\
\hline McDowell, N.C. & 284 & 393 & 677 \\
\hline Anderson & 309 & 328 & 637 \\
\hline Henderson, N.C. & 435 & 199 & 634 \\
\hline Mecklenburg, N.C. & 323 & 298 & 621 \\
\hline Polk, N.C. & 278 & 207 & 485 \\
\hline Greenwood & 249 & 209 & 458 \\
\hline Fairfield & 271 & 126 & 397 \\
\hline Kershaw & 277 & 91 & 368 \\
\hline Jasper & 174 & 126 & 300 \\
\hline Pickens & 125 & 142 & 267 \\
\hline Edgefield & 176 & 62 & 238 \\
\hline Georgetown & 170 & 30 & 200 \\
\hline Lee & 116 & 25 & 141 \\
\hline Buncombe, N.C. & 70 & 65 & 135 \\
\hline Avery, N.C. & 70 & 22 & 92 \\
\hline Abbeville & 35 & 49 & 84 \\
\hline Wilkes, N.C. & 3 & 32 & 35 \\
\hline Watauga, N.C. & 7 & 7 & 14 \\
\hline Mitchell, N.C. & 1 & 1 & 2 \\
\hline Transylvania, N.C. & 1 & 1 & 2 \\
\hline Total & 42,755 & 36,024 & 78,779 \\
\hline
\end{tabular}


Table 10. Fertilizer and manure phosphorus application rates in the SANT study area by county, 1987 (fertilizer), 1992 (manure)

[County in South Carolina except where indicated; units in tons per year]

\begin{tabular}{|c|c|c|c|}
\hline County & Fertilizer phosphorus & Manure phosphorus & Total phosphorus \\
\hline Orangeburg & 2,239 & 1,018 & 3,257 \\
\hline Lexington & 578 & 1,171 & 1,749 \\
\hline Union, N.C. & 438 & 880 & 1,318 \\
\hline Newberry & 677 & 588 & 1,265 \\
\hline Saluda & 641 & 573 & 1,214 \\
\hline Cleveland, N.C. & 612 & 485 & 1,097 \\
\hline Spartanburg & 711 & 292 & 1,003 \\
\hline Calhoun & 696 & 264 & 960 \\
\hline Bamberg & 704 & 210 & 914 \\
\hline Alexander, N.C. & 332 & 553 & 885 \\
\hline Laurens & 468 & 377 & 845 \\
\hline Colleton & 549 & 247 & 796 \\
\hline Hampton & 700 & 89 & 789 \\
\hline Lincoln, N.C. & 494 & 289 & 783 \\
\hline Clarendon & 618 & 157 & 775 \\
\hline York & 396 & 352 & 748 \\
\hline Catawba, N.C. & 458 & 253 & 711 \\
\hline Greenville & 445 & 202 & 647 \\
\hline Aiken & 229 & 337 & 566 \\
\hline Dorchester & 354 & 157 & 511 \\
\hline Sumter & 376 & 129 & 505 \\
\hline Iredell, N.C. & 284 & 216 & 500 \\
\hline Burke, N.C. & 206 & 273 & 479 \\
\hline Charleston & 437 & 25 & 462 \\
\hline Rutherford, N.C. & 292 & 170 & 462 \\
\hline Richland & 321 & 93 & 414 \\
\hline Gaston, N.C. & 254 & 131 & 385 \\
\hline Williamsburg & 319 & 51 & 370 \\
\hline Berkeley & 266 & 100 & 366 \\
\hline Cherokee & 193 & 167 & 360 \\
\hline
\end{tabular}


Table 10. Fertilizer and manure phosphorus application rates in the SANT study area by county, 1987 (fertilizer), 1992 (manure)--Continued

[County in South Carolina except where indicated; units in tons per year]

\begin{tabular}{|c|c|c|c|}
\hline County & Fertillzer phosphorus & Manure phosphorus & Total phosphorus \\
\hline Barnwell & 260 & 100 & 360 \\
\hline Chester & 156 & 200 & 356 \\
\hline Allendale & 305 & 16 & 321 \\
\hline Beaufort & 270 & 22 & 292 \\
\hline Caldwell, N.C. & 132 & 140 & 272 \\
\hline Union & 148 & 111 & 259 \\
\hline Lancaster & 126 & 124 & 250 \\
\hline McDowell, N.C. & 132 & 113 & 245 \\
\hline Henderson, N.C. & 202 & 39 & 241 \\
\hline Anderson & 128 & 96 & 224 \\
\hline Mecklenburg, N.C. & 150 & 70 & 220 \\
\hline Polk, N.C. & 129 & 53 & 182 \\
\hline Greenwood & 103 & 63 & 166 \\
\hline Kershaw & 115 & 29 & 144 \\
\hline Fairfield & 112 & 30 & 142 \\
\hline Jasper & 71 & 53 & 124 \\
\hline Pickens & 52 & 42 & 94 \\
\hline Edgefield & 73 & 17 & 90 \\
\hline Georgetown & 70 & 12 & 82 \\
\hline Lee & 48 & 9 & 57 \\
\hline Buncombe, N.C. & 32 & 15 & 47 \\
\hline Avery, N.C. & 32 & 6 & 38 \\
\hline Abbeville & 15 & 14 & 29 \\
\hline Wilkes & 1 & 10 & 11 \\
\hline Watauga, N.C. & 3 & 2 & 5 \\
\hline Mitchell, N.C. & 1 & 0 & 1 \\
\hline Transylvania, N.C. & 1 & 0 & 1 \\
\hline Total & 18,154 & 11,235 & 29,389 \\
\hline
\end{tabular}


Estimated nonpoint-source loads of total nitrogen and total phosphorus from agricultural sources were 79 and 29 kilotons per year (ktons/yr), respectively. Significantly greater amounts of nitrogen were contributed from atmospheric sources than from agricultural sources in the SANT study area (fig. 26). Fertilizer applications accounted for slightly higher loads of nitrogen and phosphorus than manure applications.

\section{Point Sources}

National Pollutant Discharge Elimination System (NPDES) permit data were obtained from the USEPA PCS database. The information for both North Carolina and South Carolina were incomplete so analyses reported here are based on the available data.

In 1995, the database listed 937 permitted pointsource discharges in the study area, but only 360 of the
937 facilities had reported discharge volumes. Of those, 114 facilities had permitted discharge volumes greater than $0.5 \mathrm{Mgal} / \mathrm{d}$. The total flows calculated for the 360 facilities was about $450 \mathrm{Mgal} / \mathrm{d}$, however this figure represents a significant underestimate of pointsource discharge volume because of missing data.

A separate retrieval was made of the August 1995 discharge monitoring reports (DMR) for permitted facilities. The DMR retrieval provided data for only 121 facilities. Those facilities had a combined permitted flow of at least $380 \mathrm{Mgal} / \mathrm{d}$. The reported average flow for those facilities in August 1995 was over 9,500 $\mathrm{Mgal} / \mathrm{d}$ due to inclusion of monitored flows that had no permit limit. Estimating nutrient loads from pointsource discharges was not possible because not all facilities were required to report discharge volume or concentration data.

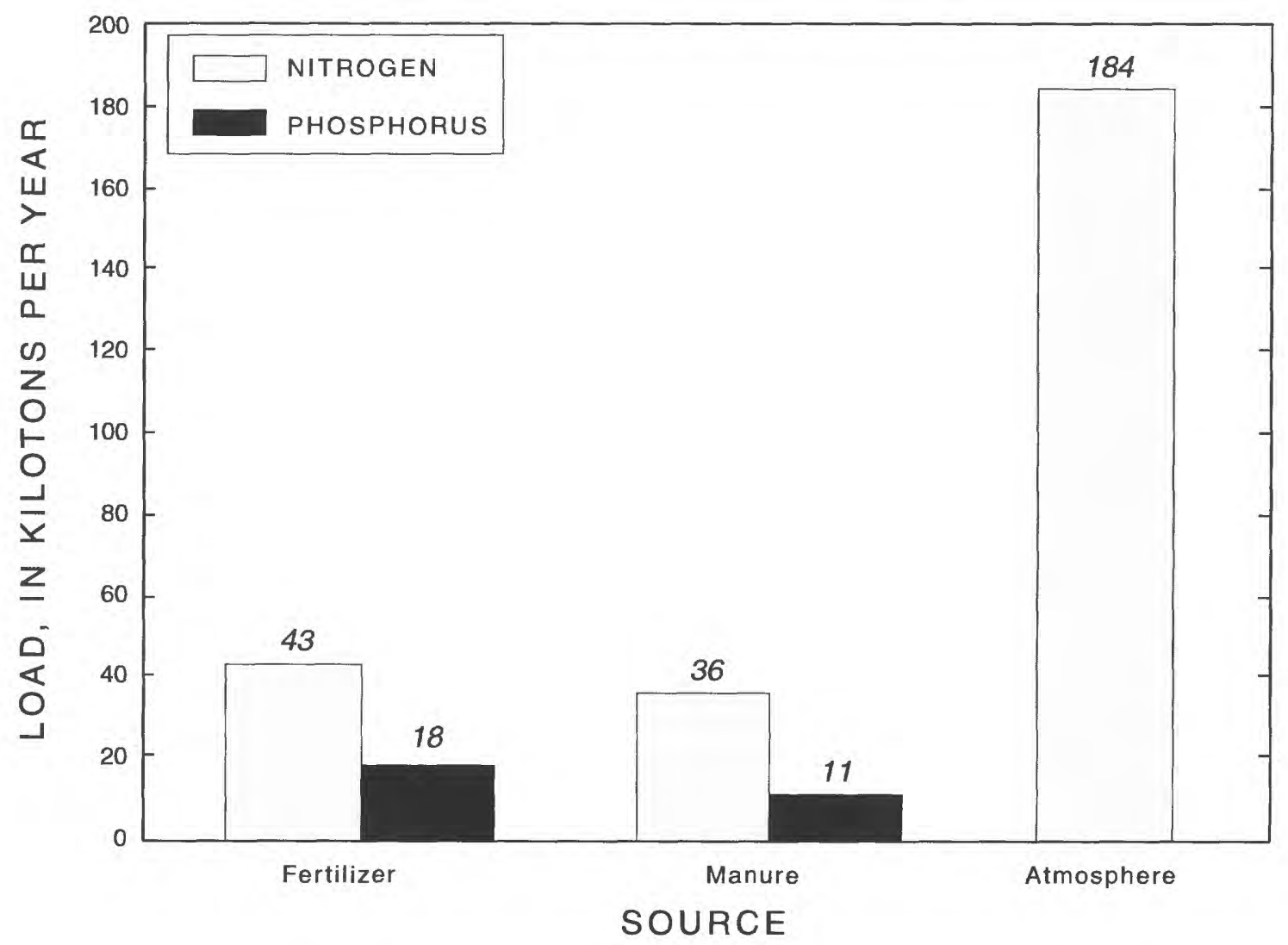

Fiaure 26. Nonpoint-source nitrogen and phosphorus loads in the SANT study area. 


\section{Nutrient Load Comparisons for Selected Stations}

Nutrient load calculations are useful for comparing and contrasting relative contributions of nutrients from different drainage basins, and for determining the mass of a nutrient flowing in a stream. The magnitude of nutrient loads entering reservoirs is important because of eutrophication concerns. Total loads leaving reservoirs can be useful information to help determine if nutrients are being stored in or exported from the reservoir.

Seven stations in the SANT study area (fig. 27) had sufficient ambient water-quality and streamflow data to estimate nutrient loads. Minimum requirements included: the station was sampled during 1973-93; the samples were collected quarterly or more frequently; and the station had no more than 5 continuous years of missing data. Four of the stations were in the Broad River drainage basin; the other three were in the Saluda River drainage basin. The sum of the loads at the upstream-most station plus any tributary loads was compared with loads at the downstream-most station. Both the Broad and Saluda River drainage basins had reservoirs between the upstream and downstream stations.

Monthly water-quality data obtained from STORET provided concentrations for ammonia nitrogen, nitrite-plus-nitrate nitrogen, total Kjeldahl nitrogen, and total phosphorus. Daily mean streamflows at the corresponding USGS stations also were used.

Monthly medians of concentration and streamflow were calculated for each of the twelve months over the period of study. Similarly, annual medians of concentration and streamflow were calculated for each year over the period of study. These medians were then used to calculate monthly and annual median loads at each of the seven stations. Percentage differences between upstream and downstream loads were estimated.

Monthly and annual median loads are shown graphically. As described earlier, this method likely underestimates loads of nutrients because high-flow events are not routinely sampled for water quality.

\section{Broad River and Tributaries}

Nutrient loads were compared among four water-quality stations located in the Broad River drainage: an upstream Broad River station near Carlisle (B-046), the Tyger River upstream from the confluence with the Broad (B-051), the Enoree River upstream from the confluence with the Broad (B-054), and a downstream Broad River station below the Parr Reservoir (B-236). A drainage basin of approximately 770 $\mathrm{mi}^{2}$ is located between the lower Broad River station and the upper Broad, the Tyger, and the Enoree River stations (fig. 27). Several small tributaries enter the Broad River in this area but have no available water quality or quantity data.

\section{Streamflows}

Streamflow data in the Broad River drainage basin used for computing loads are summarized in table 11. Parr Reservoir is located on the Broad River between the upstream stations and the downstream station. Parr Reservoir has a surface area of 4,400 acres and a volume of 32,533 acre-ft (S.C. Water Resources Commission, 1991). The drainage basin is approximately 4,600 $\mathrm{mi}^{2}$, and the mean annual streamflow into Parr Reservoir is approximately $5,700 \mathrm{ft}^{3} / \mathrm{s}$ (U.S. Geological Survey, 1995). The estimated residence time is less than 3 days. Parr Reservoir is a pump-storage reservoir with high turbidity and a large sediment load.

Table 11. Streamflows at selected U.S. Geological Survey (USGS) gaging stations in the Broad River drainage basin (USGS gaging station number in parentheses) (from Cooney and others, 1995)

[Units in cubic feet per second]

\begin{tabular}{cccc}
\hline Station & $\begin{array}{c}\text { Period of } \\
\text { record }\end{array}$ & $\begin{array}{c}\text { Range of } \\
\text { monthly } \\
\text { medians }\end{array}$ & $\begin{array}{c}\text { Range of } \\
\text { annual } \\
\text { medians }\end{array}$ \\
\hline $\begin{array}{c}\text { Upstream } \\
\text { Broad River } \\
(02156500)\end{array}$ & $1973-93$ & $1,900-4,660$ & $1,475-4,280$ \\
$\begin{array}{c}\text { Tyger River } \\
(02160105)\end{array}$ & $1973-93$ & $379-1,160$ & $340-1,050$ \\
$\begin{array}{c}\text { Enoree River } \\
(02160700)\end{array}$ & $1973-93$ & $210-686$ & $200-554$ \\
$\begin{array}{c}\text { Downstream } \\
\text { Broad River } \\
(02161000)\end{array}$ & $1980-93$ & $2,110-6,520$ & $2,120-5,290$ \\
\hline
\end{tabular}




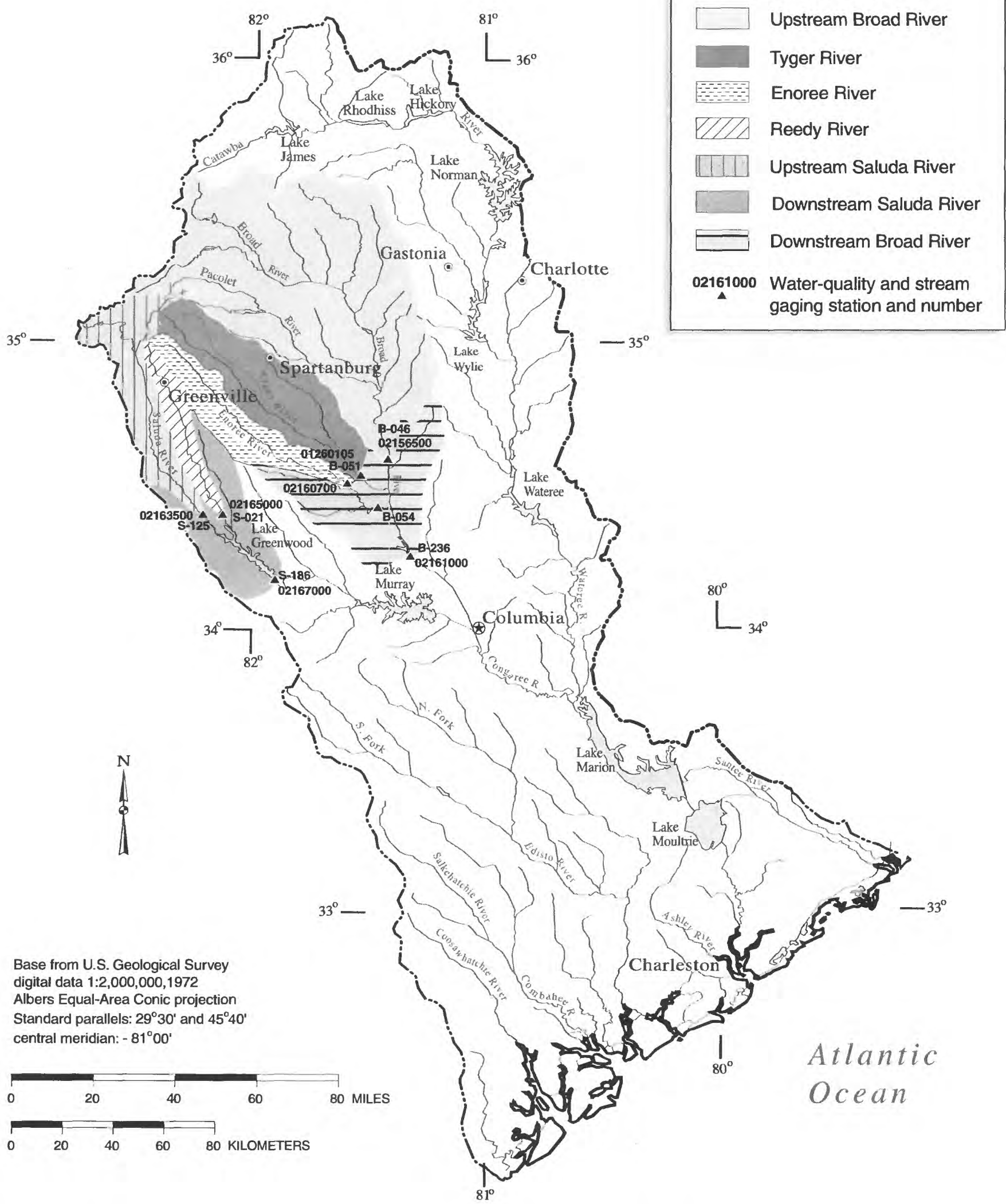

Figure 27. Selected stations for nutrient load calculations in the SANT study area. 
The lowest monthly median flows at each station occurred in September, with the sum of the medians for the upstream stations totaling $2,489 \mathrm{ft}^{3} / \mathrm{s}$ and the downstream station totaling $2,110 \mathrm{ft}^{3} / \mathrm{s}$. During low-flow periods, water may be retained in storage in Parr Reservoir, thereby decreasing flow downstream from the reservoir. The high-flow month for each station was March, with the sum of the medians for the upstream stations totaling $6,506 \mathrm{ft}^{3} / \mathrm{s}$ and the downstream station totaling $6,520 \mathrm{ft}^{3} / \mathrm{s}$. At high streamflows, Parr Reservoir volumes may remain relatively constant, allowing upstream and downstream flows to be approximately the same.

\section{Nutrient Loads}

Monthly median ammonia nitrogen loads were as much as 32 percent higher at the downstream Broad River station than the sum of the loads at the upstream stations, except during February, March, and April, when downstream loads were as much as 20 percent lower (fig. 28). Monthly ammonia nitrogen loads at the downstream station (B-236) closely followed the upstream Broad River station (B-046) load trends because of the greater proportion of the flow coming from the upstream station. Seasonal variability in loads closely follows seasonal streamflows. Annual median ammonia nitrogen loads were variable, with an overall decrease in loads after 1984 (fig. 28). This is likely because of improved wastewater treatment of ammonia nitrogen in the 1980's and 1990's.

Monthly median nitrite-plus-nitrate nitrogen loads showed a high seasonal variability (fig. 29), closely following seasonal streamflow trends. Downstream loads of nitrite-plus-nitrate nitrogen were as much as 34 percent lower than the total of the upstream loads during the summer months, probably indicating assimilation in Parr Reservoir. Annual nitrite-plusnitrate nitrogen loads were variable, with downstream loads generally lower than the sum of the upstream loads (fig. 29), showing again the probable impact of Parr Reservoir.

Total Kjeldahl nitrogen followed a similar seasonal trend as nitrite-plus-nitrate nitrogen. Higher loads of total Kjeldahl nitrogen were observed downstream during the winter and spring and lower loads were observed downstream during the summer and fall months, possibly due to increased assimilation during the warmer months (fig. 30). Annual loads of total Kjeldahl nitrogen were as much as 33 percent lower at the downstream Broad River station than the sum of the upstream loads from 1980 to 1987 , but from 1988 to 1993 the downstream annual median total Kjeldahl nitrogen load was as much as 58 percent higher than the total of the upstream loads (fig. 30).

Total phosphorus loads downstream from Parr Reservoir were between 12 and 57 percent lower than the upstream monthly median load (fig. 31). Annual median loads also show reductions in phosphorus between the upstream and downstream stations, indicating that the reservoir was a sink for total phosphorus. Reductions in annual median total phosphorus between the downstream station and the sum of the upstream stations range from 15 to 47 percent (fig. 31). Phosphorus in reservoirs is readily assimilated by biota, and is also likely to precipitate or sorb onto particles in the water column.

\section{Contributions from Nonpoint Sources}

Nonpoint-source nitrogen loads in the Broad, Tyger, and Enoree River drainage basins were dominated by atmospheric deposition (fig. 32). Nonpointsource phosphorus loads in this drainage basin from fertilizer applications were higher than from manure applications (fig. 33). Nonpoint-source load estimates at the downstream station represent only the drainage area falling between the upstream and downstream stations.

\section{Saluda and Reedy Rivers}

Three water-quality stations located in the Saluda River drainage basin were used for nutrient load comparisons: the Reedy River near Ware Shoals (S-021), the Saluda River near Ware Shoals (S-125), and the Saluda River below Lake Greenwood (S-186). Streamflow data from nearby USGS gaging stations were used in calculating loads at those stations. The Reedy and Saluda Rivers drain into separate arms of Lake Greenwood (fig. 27). A drainage basin of approximately $580 \mathrm{mi}^{2}$ falls between the upstream stations and the downstream Saluda River station below Lake Greenwood. 

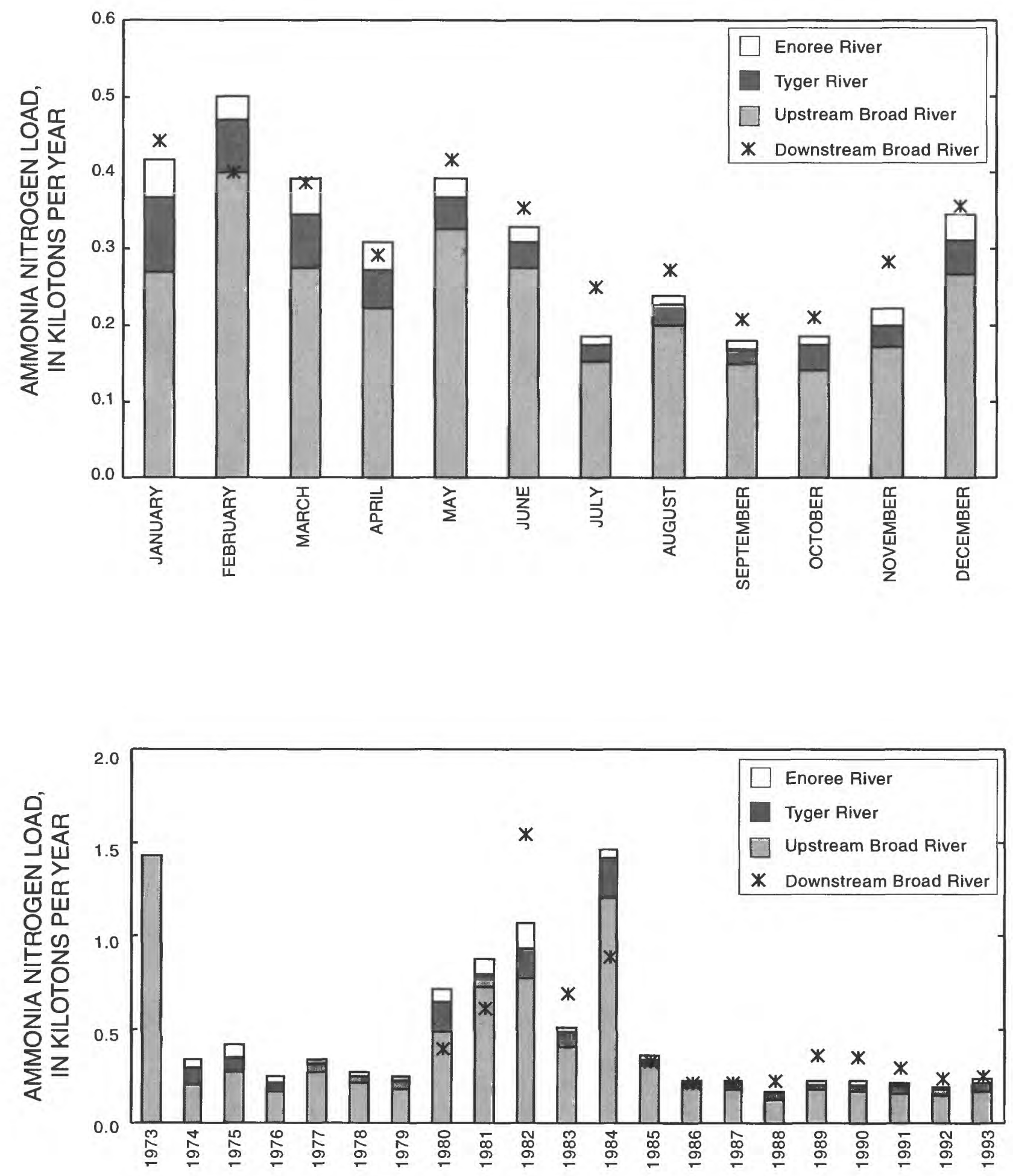

Figure 28. Median monthly and annual ammonia nitrogen loads in the Broad, Tyger, and Enoree Rivers, SANT study area, 1973-93. 

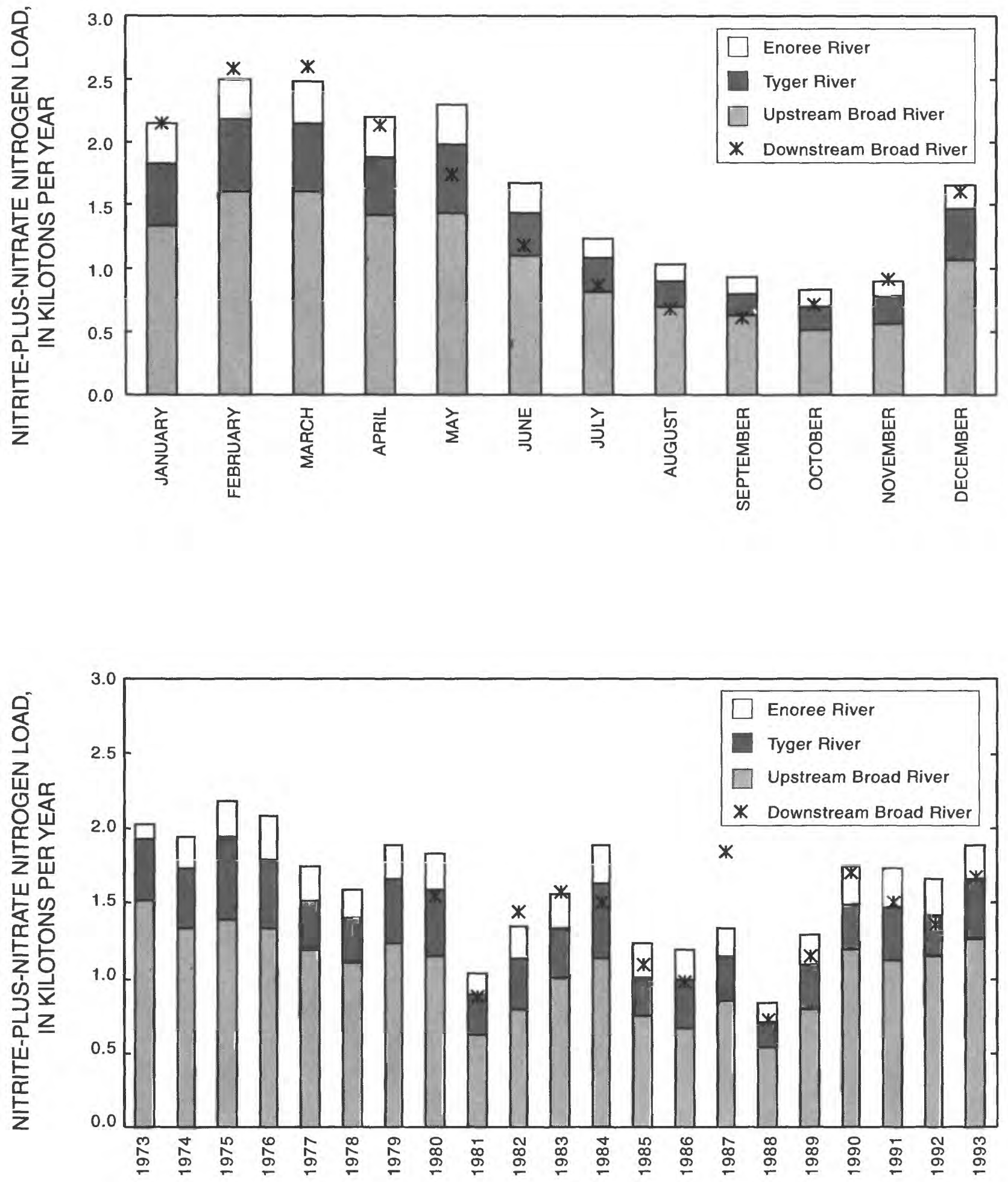

Figure 29. Median monthly and annual nitrite-plus-nitrate loads in the Broad, Tyger, and Enoree Rivers, SANT study area, 1973-93. 

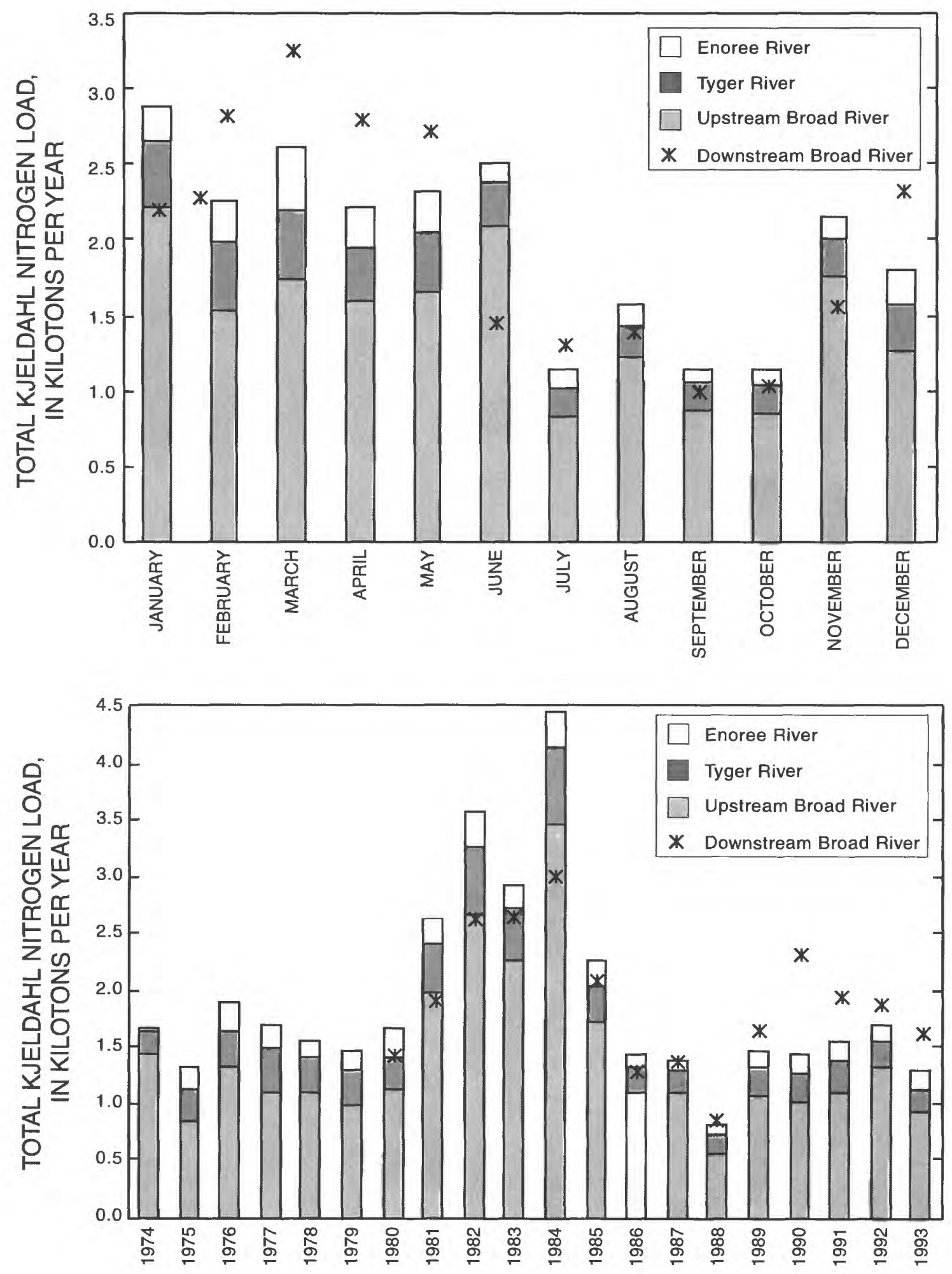

Figure 30. Median monthly and annual total Kjeldahl nitrogen loads in the Broad, Tyger, and Enoree Rivers, SANT study area, 1974-93. 

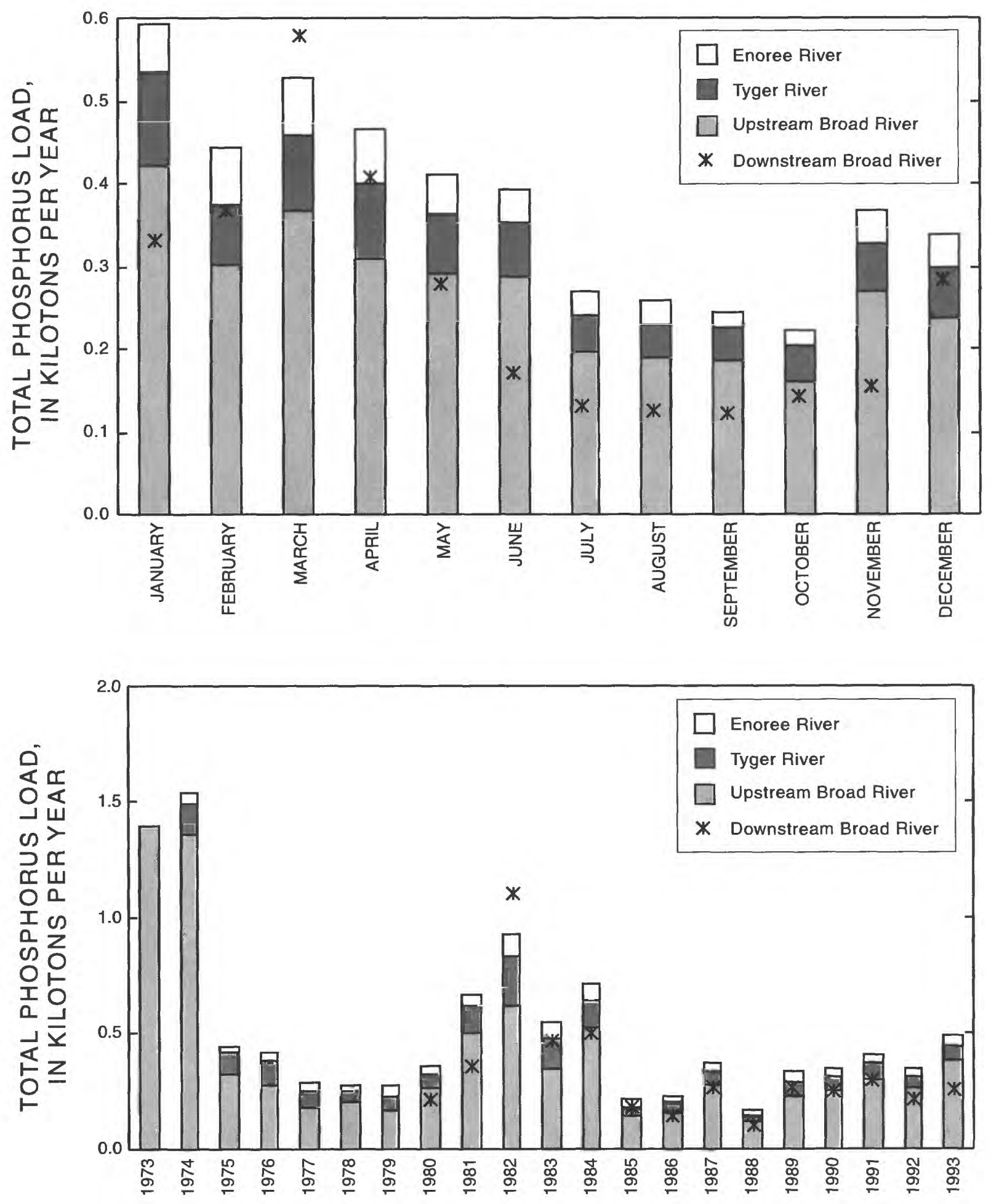

Figure 31. Median monthly and annual total phophorus loads in the Broad, Tyger, and Enoree Rivers, SANT study area, 1973-93. 


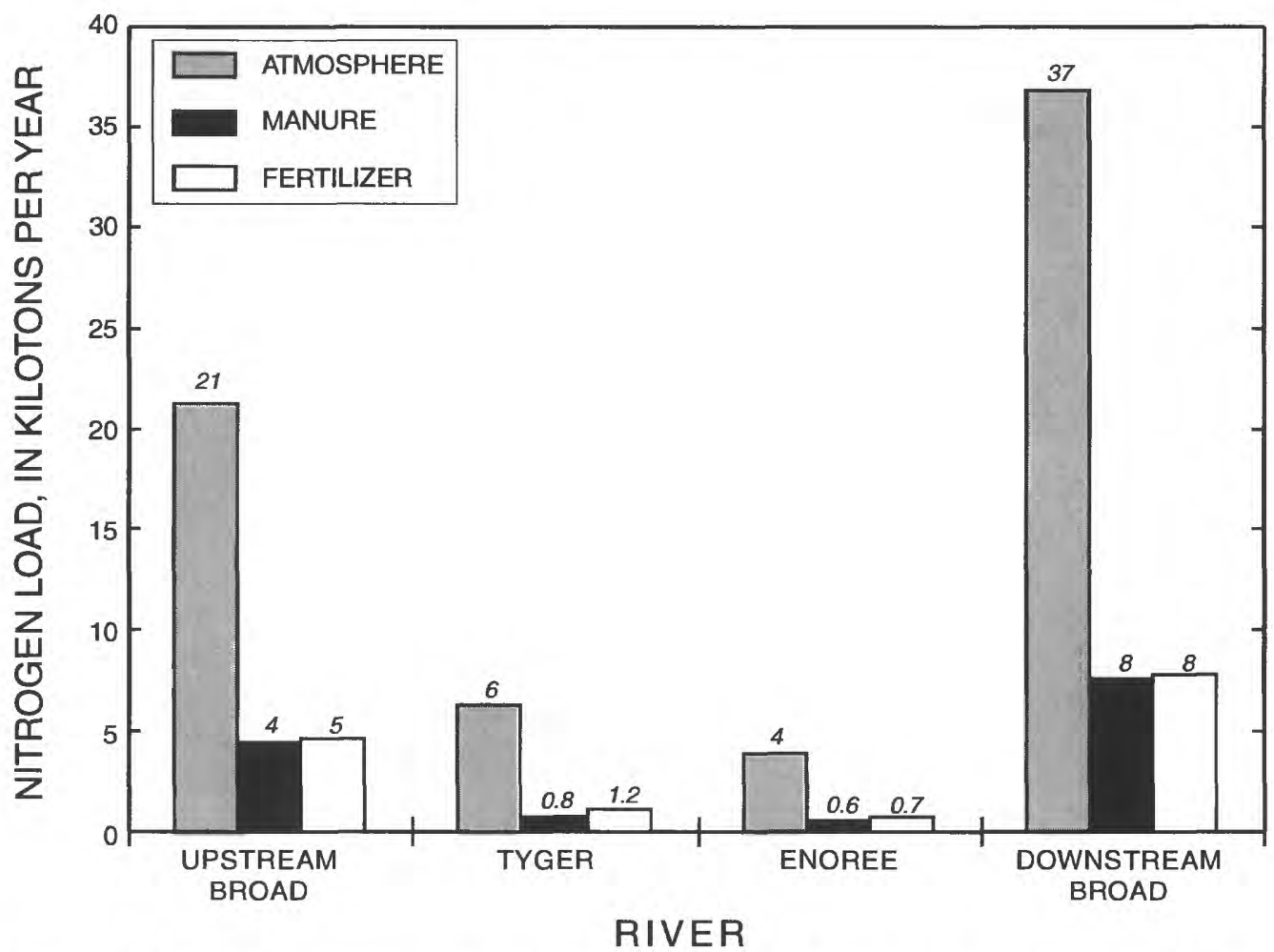

Figure 32. Nonpoint-source nitrogen loads in the Broad River drainage basin, SANT study area.

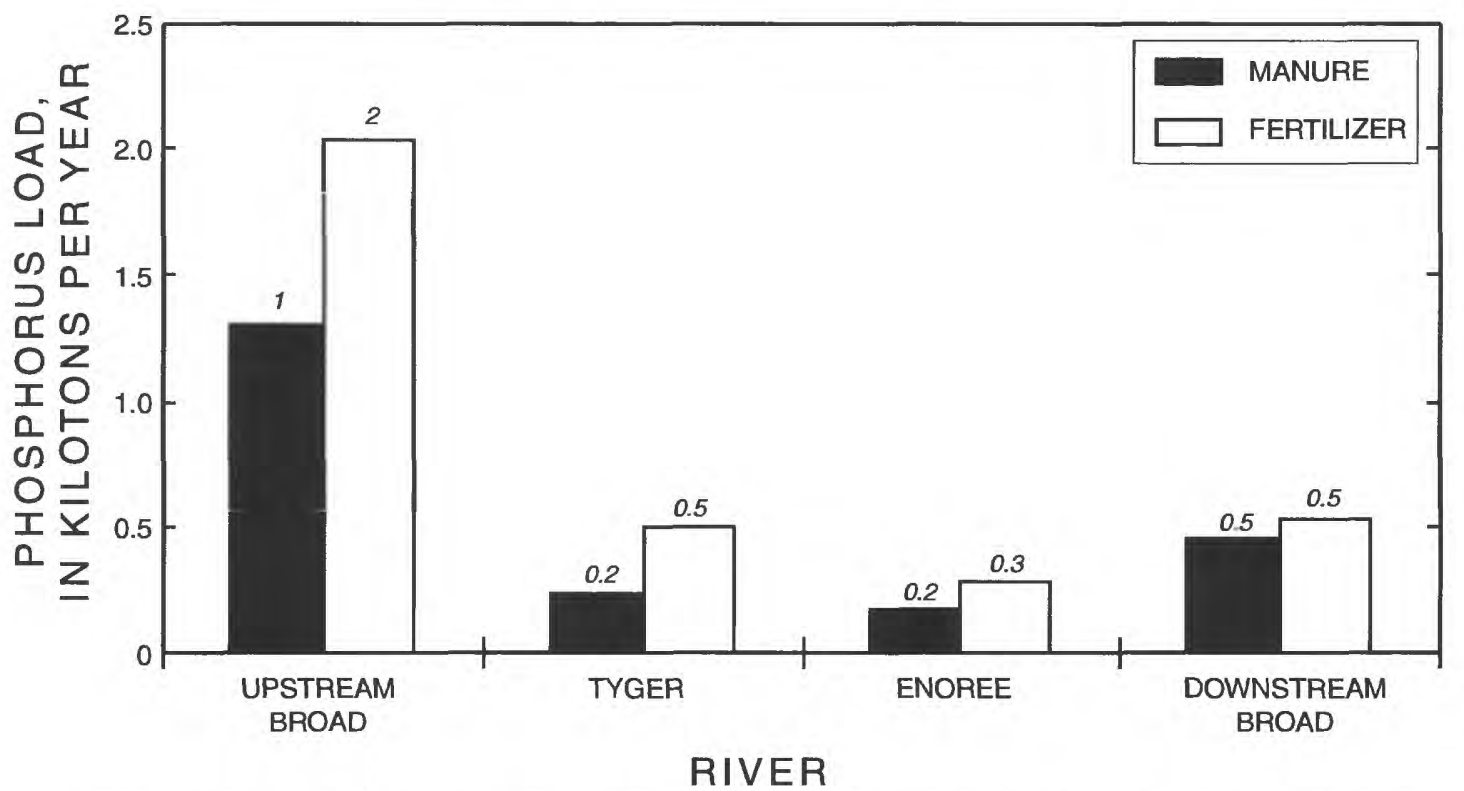

Figure 33. Nonpoint-source phosphorus loads in the Broad River drainage basin, SANT study area. 


\section{Streamflows}

Streamflows in the Saluda River drainage basin are summarized in table 12. Lake Greenwood is located above the downstream Saluda River station and has a drainage basin of approximately $1,130 \mathrm{mi}^{2}$. Lake Greenwood has a surface area of 11,400 acres and a volume of 270,000 acre-ft (S.C. Water Resources Commission, 1991). The mean annual streamflow into the lake is approximately $1,700 \mathrm{ft}^{3} / \mathrm{s}$. The estimated residence time is approximately 81 days. Lake Greenwood stratifies from April through mid-September or October, but fully circulates during the winter

Table 12. Streamflows at selected U.S. Geological Survey (USGS) gaging stations in the Saluda River drainage basin (USGS gaging station number in parentheses) (from Cooney and others, 1995)

[Units in cubic feet per second]

\begin{tabular}{cccc}
\hline Station & $\begin{array}{c}\text { Period of } \\
\text { record }\end{array}$ & $\begin{array}{c}\text { Range of } \\
\text { monthly } \\
\text { medians }\end{array}$ & $\begin{array}{c}\text { Range of } \\
\text { annual } \\
\text { medians }\end{array}$ \\
\hline $\begin{array}{c}\text { Upstream } \\
\text { Saluda River } \\
(02163500)\end{array}$ & $1973-93$ & $478-1,195$ & $366-1,180$ \\
$\begin{array}{c}\text { Reedy River } \\
(02165000)\end{array}$ & $1973-93$ & $170-466$ & $152-392$ \\
$\begin{array}{c}\text { Downstream } \\
\text { Saluda River } \\
(02167000)\end{array}$ & $1973-93$ & $733-2,360$ & $426-2,510$ \\
\hline
\end{tabular}

\section{Nutrient Loads}

Median ammonia nitrogen loads were seasonal, with higher loads in the winter than in the summer months. Higher loads were observed at the downstream Saluda River station (S-186) than the sum of the upstream loads (S-021 and S-125) (fig. 34). One possible reason for this may be unquantified nutrient loads entering the system between the upstream stations and the downstream station. Annual median load trends were similar in the two Saluda River stations (S-125 and S-186) due to the relatively higher percentage of the flow at the lower station contributed by the Saluda rather than the Reedy River. The annual median load in the Reedy River decreased, probably due to increased ammonia nitrogen removal efficiencies at wastewatertreatment plants. Annual median ammonia nitrogen loads show a decreasing trend (fig. 34). In 1992 and
1993 the percentage difference between upstream and downstream loads decreased.

Tributaries flowing directly into Lake Greenwood, such as Wilson Creek and Ninety Six Creek, carry nutrient loads from wastewater-treatment plants. Better ammonia-nitrogen removal from these discharges may explain the decrease in the downstream Saluda River loads in recent years.

Monthly median loads of nitrite-plus-nitrate nitrogen showed a similar seasonal trend to the Broad River Basin, with Lake Greenwood acting as a source of nitrite-plus-nitrate nitrogen in January and February, and a sink during the rest of the year (fig. 35). The seasonal trend was more prominent in the Saluda River Basin because Lake Greenwood is a larger lake than the Parr Reservoir, has a more pronounced seasonal stratification, and a longer residence time. Decreases in monthly median loads between the sum of the upstream stations and the downstream station ranged between 11 and 94 percent. Annual median loads of nitrite-plus-nitrate nitrogen (fig. 35) were variable, especially at the downstream Saluda River station. Loads were lower (up to 91 percent) at the downstream station than the sum of the upstream stations for all years except 1975 .

Total Kjeldahl nitrogen trends were seasonal and closely followed seasonal streamflows (fig. 36).

Monthly median loads at the downstream Saluda River station were between 10 and 81 percent greater than the combined upstream loads. Annual median loads of total Kjeldahl nitrogen were variable and generally higher (up to 82 percent) at the downstream station than the sum of the upstream stations (fig. 36).

Total phosphorus trends were similar to those in the Broad River drainage basin. At the downstream Saluda River station, monthly and annual median loads were generally well beiow the sum of the upstream loads. Reductions in monthly median phosphorus loads in Lake Greenwood were estimated to be as high as 64 percent. The monthly loads at the downstream station aiso exhibited a seasonal trend (fig. 37). Annual loads were generally lower at the downstream station, with reductions in annual medians between the sum of upstream loads and the downstream load ranging from 24 to 80 percent. As mentioned previously, phosphorusin reservoirs is readily assimilated by biota, and is also likely to precipitate or sorb onto particles in the water column. Annual median loads of phosphorus in the Saluda Basin show a decreasing temporal trend, 

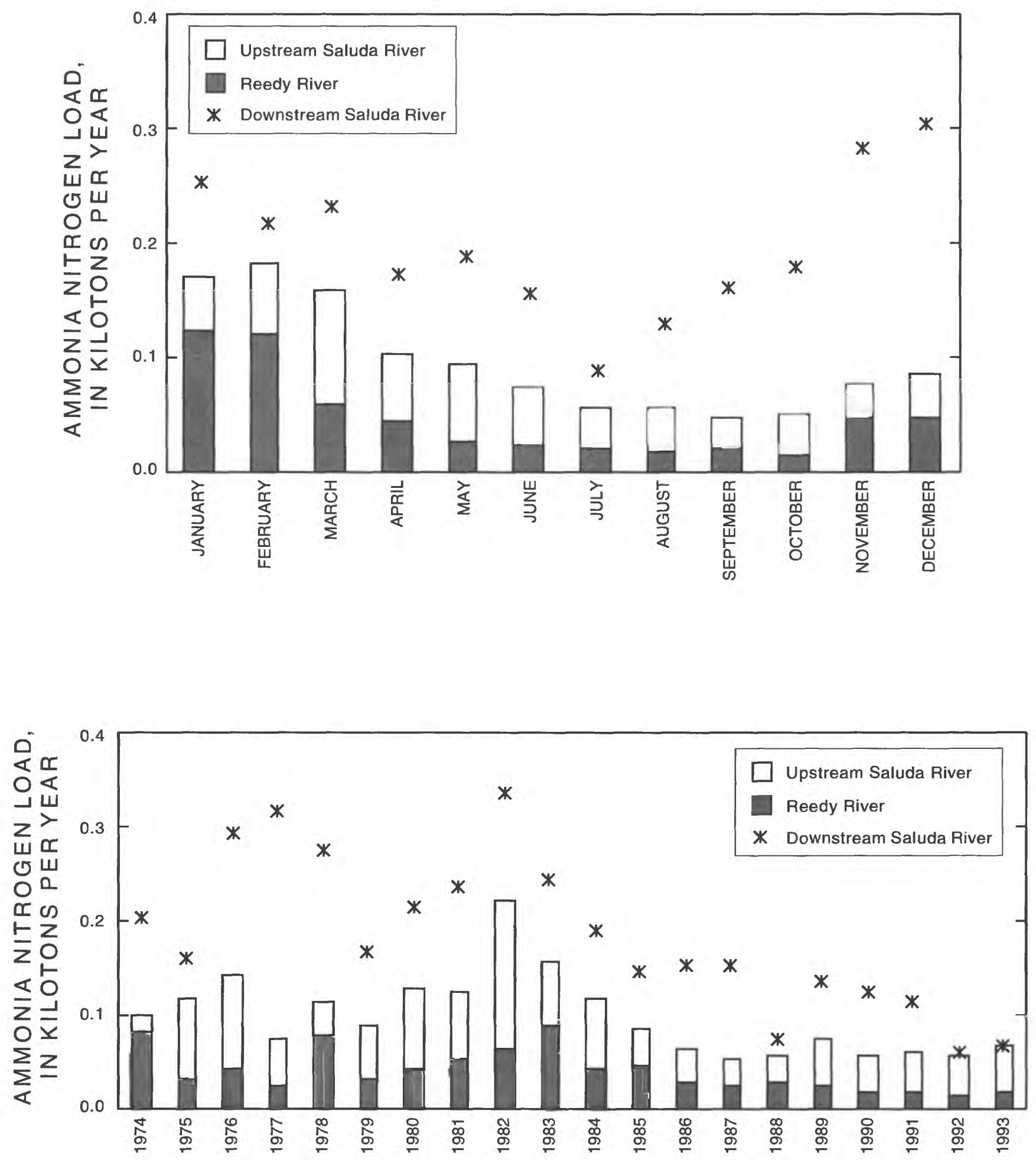

Figure 34. Median monthly and annual ammonia nitrogen loads in the Saluda and Reedy Rivers, SANT study area, 1974-93. 

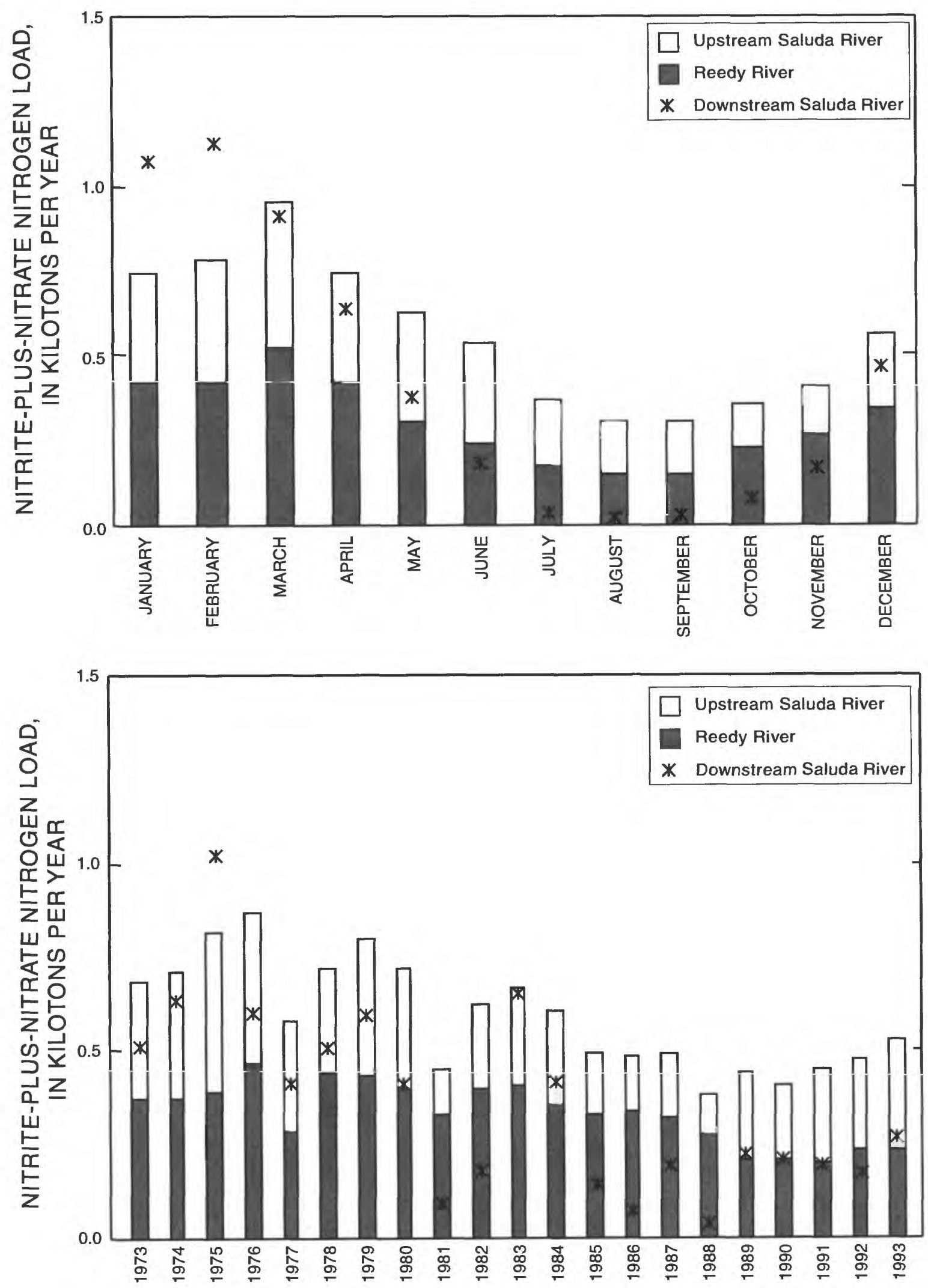

Figure 35. Median monthly and annual nitrite-plus-nitrate nitrogen loads in the Saluda and Reedy Rivers, SANT study area, 1973-93. 

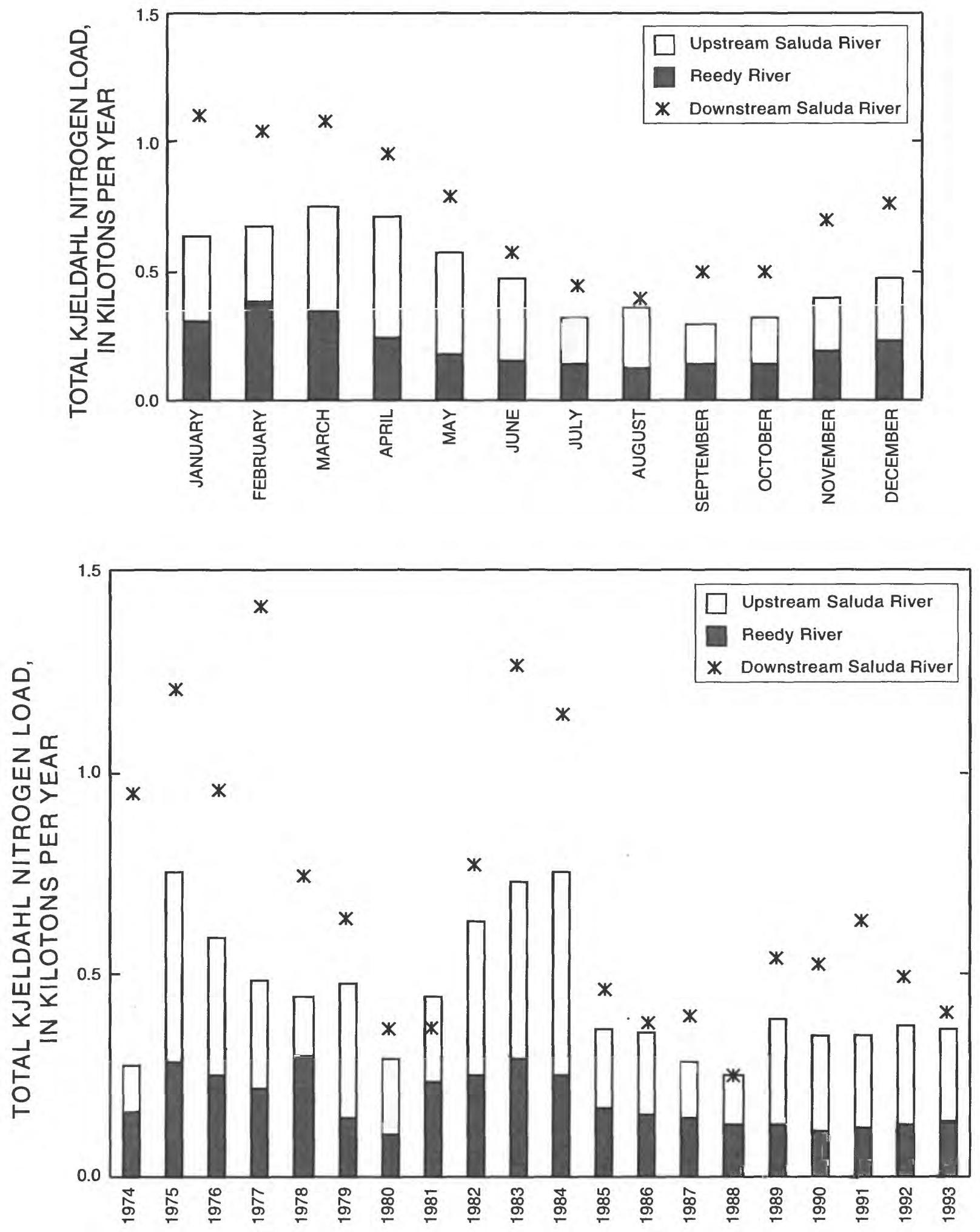

Figure 36. Median monthly and annual total Kjeldahl nitrogen loads in the Saluda and Reedy Rivers, SANT study area, 1974-93. 

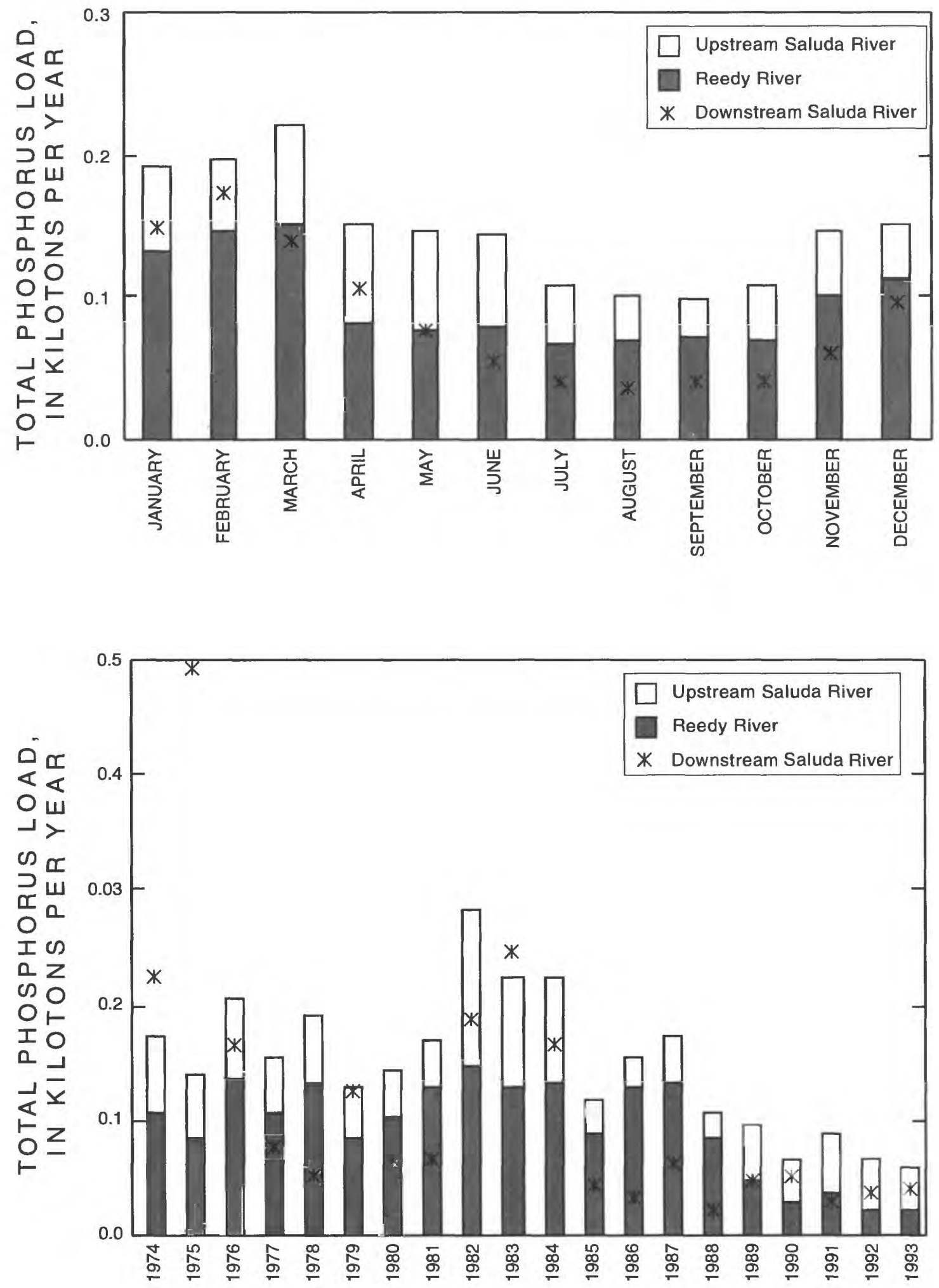

Figure 37. Median monthly and annual total phosphorus loads in the Saluda and Reedy Rivers, SANT study area, 1974-93. 
possibly due to increased regulation on the pointsource discharge of phosphorus to the Reedy River.

\section{Contributions from Nonpoint Sources}

Nonpoint-source nitrogen loads in the Saluda and Reedy River drainage basins were dominated by atmospheric deposition (fig. 38), and nonpoint-source phosphorus loads were higher from fertilizer than from manure applications (fig. 39). Nonpoint-source load estimates at the downstream station represent only the drainage area falling between the upstream and downstream stations.

\section{NUTRIENTS IN GROUND WATER}

Ground water is the source of drinking water for slightly less than half of the study area population. Approximately 20 percent of the public water supplies, and nearly 100 percent of the private domestic water supplies are dependent upon ground water. Water-quality problems in the study area include large concentrations of inorganic constituents in the water (Patterson and Padgett, 1984), contamination by man-made chemicals (Daniel and others, 1992), and high salinity water (Newcome, 1989).

One of the greatest water-quality concerns in the study area is the elevated concentrations of nitrate in ground water. High concentrations of nitrate in drinking water can cause a variety of health problems. Nitrate is naturally introduced into the ground water from decomposing organic matter and from soils and rocks. Anthropogenic causes include fertilizer use, septic systems, sewage effluent, industrial discharges, and atmospheric deposition. Generally, highest groundwater nitrate concentrations are associated with agricultural areas, where fertilizer and manure is regularly applied to the land surface (Mueller and others, 1995). Approximately 18 and 7 percent of the study area is used for cropland and pasture, respectively.

\section{Methods}

Data were retrieved from three databases to assess nitrate concentrations in ground water. The data bases consisted of the SCDHEC ambient water-quality network (SCDHEC network), a Clemson University agriculturally influenced chemical study (Clemson network), and a joint USGS and SCDHEC compilation of ground-water quality (USGS network) that was conducted as part of the USGS National Water Summary (Speiran and others, 1986). The SCDHEC network is comprised of selected public and private water-supply wells. In 1994, 105 wells were located in the SANT study area. Data from 54 wells out of the 105 SCDHEC wells were usable for this study area because of limited well location and construction data.

The Clemson network established by the College of Agricultural Sciences, Clemson University, utilized selected potable water-supply wells, non-potable wells, and monitoring wells. Well sites included farms, residences, golf courses, and pesticide loading stations. The sampling program was designed to determine the distribution and range in concentration of agricultural chemicals in ground water in South Carolina. The initial phase of this program began in 1991 and focused on areas at risk of ground-water contamination from agricultural chemicals and fertilizers. Once the majority of the most vulnerable sites were investigated, the sampling program expanded to all counties of the state. This second phase of sampling began in 1993 and is an ongoing project.

A summary of ground-water nitrate concentrations for South Carolina was jointly compiled by SCDHEC and USGS as part of the USGS National Water Summary (Speiran and others, 1986). The National Water Summary represents nitrate concentrations obtained from ground-water samples collected during 1946-85 in South Carolina. Most of the data were collected between 1950-60. There have been little nitrate data loaded into the USGS network for South Carolina since 1985. Although sampling protocols and detection limits most likely changed during this period, no attempt was made to adjust for the effects of these changes on the data. The variability of water-quality among the aquifers in South Carolina was documented by Speiran and others (1986).

Although other public water supply and hazardous waste-site databases were researched, they were not used because they were considered inappropriate to compare to the other databases, either due to the content of the data, or in some cases they lacked essential data. Data for wells in most of these databases focused on known polluted sites, such as hazardous waste disposal areas, industrial facilities, agricultural stations, and other public facilities. 


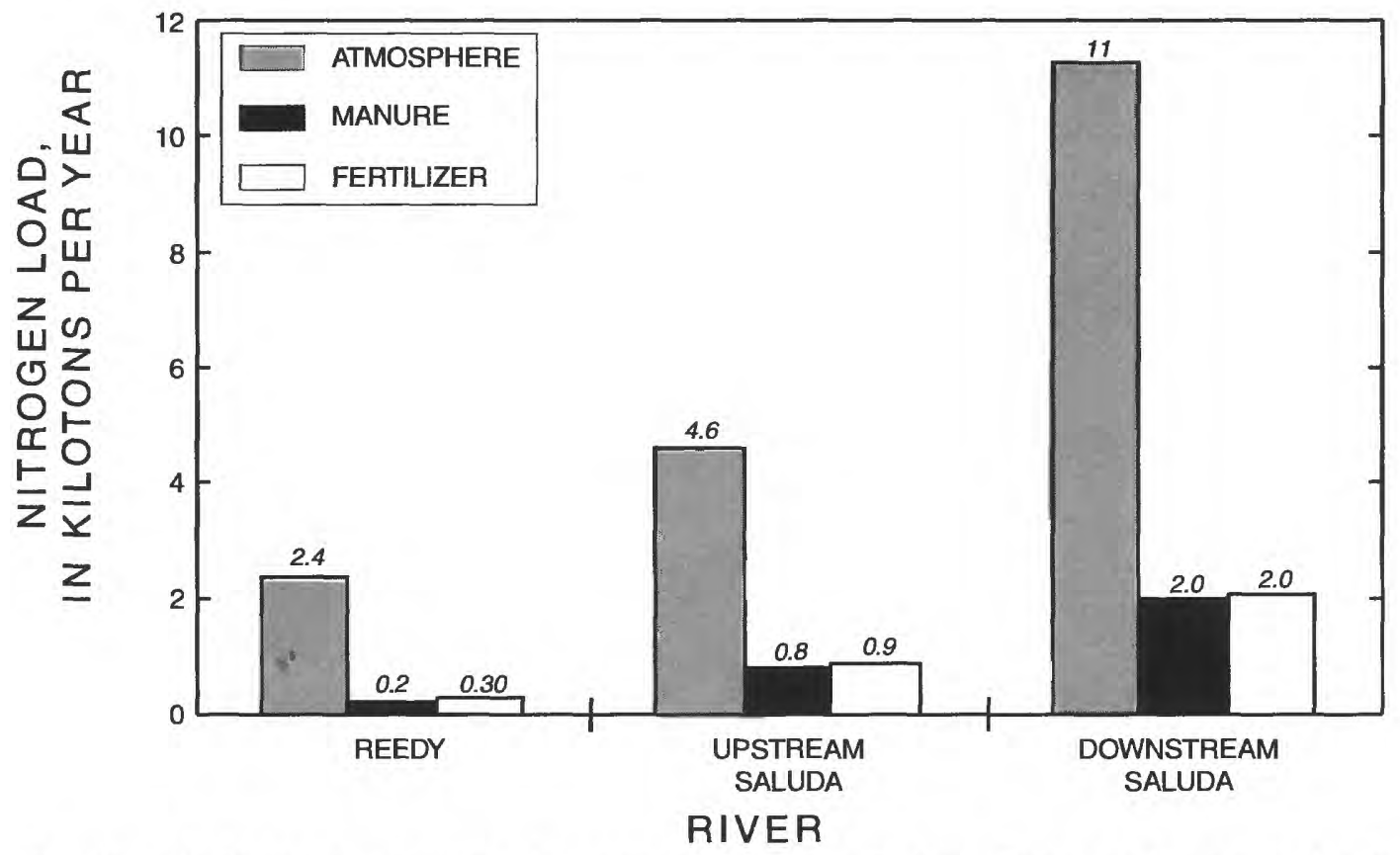

Figure 38. Nonpoint-source nitrogen loads in the Saluda River drainage basin, the SANT study area.

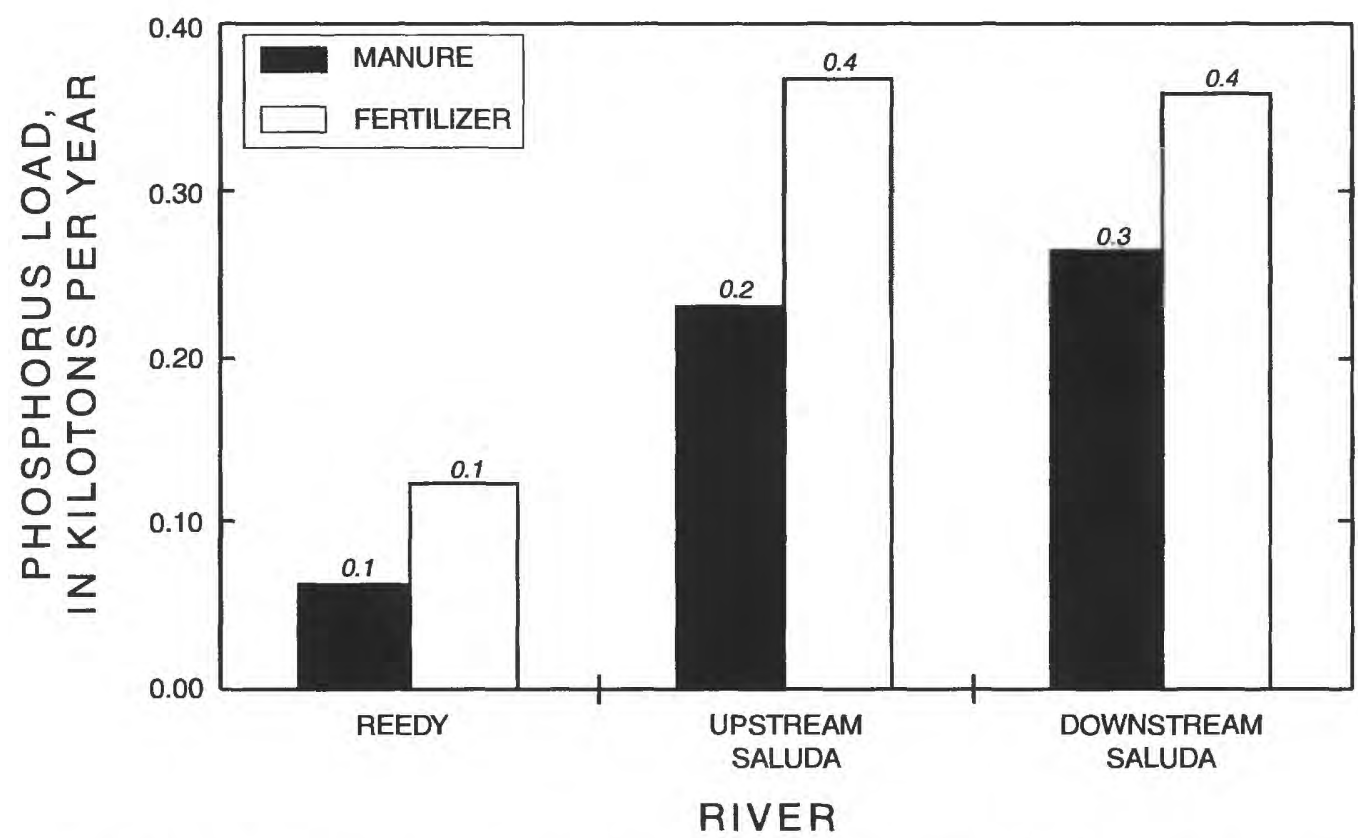

Figure 39. Nonpoint-source phosphorus loads in the Saluda River drainage basin, SANT study area. 


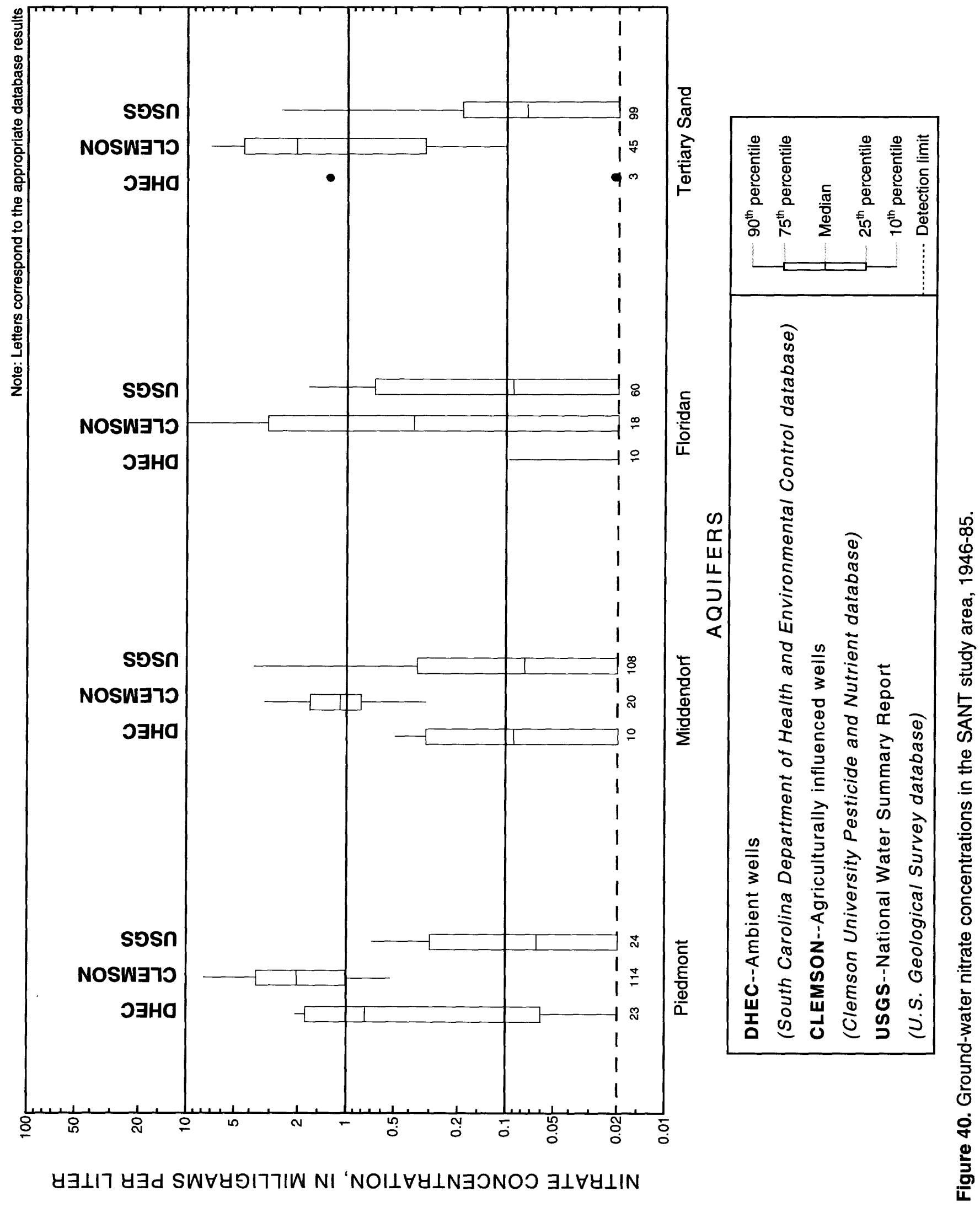




\section{Ground-Water Nitrate Concentrations}

Boxplots summarizing ground-water nitrate concentrations were constructed for each aquifer where sufficient data were available (fig. 40). A separate boxplot was prepared for each of the three networks so that comparisons could be made between the different networks. The median nitrate concentrations in the Clemson network ranged from 0.4 to $2.0 \mathrm{mg} / \mathrm{L}$, those in the SCDHEC network wells from $<0.02$ to $0.8 \mathrm{mg} / \mathrm{L}$, and those in the USGS network from 0.04 to $0.09 \mathrm{mg} / \mathrm{L}$. The Clemson network wells had the highest median nitrate concentrations in all four aquifers examined, and the concentrations were 2 to 300 times greater than those in the SCDHEC network. When compared to the USGS network, the SCDHEC network median nitrate concentrations were higher in the Piedmont aquifer, lower in the Floridan, and approximately equal in the Middendorf. Nitrate data were limited for the Black Creek aquifer because of its small area and use in the SANT study area, and therefore nitrate data for this unit were not included for this report.

For the Clemson network wells, the Piedmont and Tertiary Sand aquifers had the highest median nitrate concentrations $(2-3 \mathrm{mg} / \mathrm{L}$ ), while the Middendorf and Floridan aquifers had somewhat lower median nitrate concentrations of approximately $1 \mathrm{mg} / \mathrm{L}$ and 0.4 $\mathrm{mg} / \mathrm{L}$, respectively. The Piedmont aquifer also had the highest median concentrations of nitrate among the SCDHEC network. The median nitrate concentration of the SCDHEC network wells in the Piedmont aquifer was $0.8 \mathrm{mg} / \mathrm{L}$, which is similar to the median nitrate concentration in the Clemson network wells. The Middendorf and Floridan aquifer SCDHEC network wells had considerably lower median nitrate concentrations of $0.09 \mathrm{mg} / \mathrm{L}$ and $<0.02 \mathrm{mg} / \mathrm{L}$, respectively. There were insufficient data collected in the SCDHEC network to determine a median nitrate concentration for the Tertiary Sand aquifer. The median nitrate concentration for all the wells in the USGS network were relatively low and varied little among the aquifers, ranging from 0.04 to $0.09 \mathrm{mg} / \mathrm{L}$ (fig. 40 ).

The 90th-percentile concentration of nitrate in the Clemson network wells equaled the USEPA maximum contaminant level (MCL) for drinking water $(10.0 \mathrm{mg} / \mathrm{L})$ in the Floridan aquifer. None of the water samples collected from the Middendorf or Tertiary Sand aquifers that were included in the USGS network had nitrate concentrations which exceeded the MCL.

\section{SUMMARY}

Surface-water nutrient data from 90 stations in the SANT study area were assessed for 1973-93. Nutrient species assessed were total ammonia nitrogen, total nitrite-plus-nitrate nitrogen, total Kjeldahl nitrogen, and total phosphorus. The study area was divided into four subunits for data assessment: the Broad, Catawba, Cooper, and Edisto subunits.

The surface-water sites that consistently had the highest concentrations of nutrients were those affected by wastewater-treatment plants and nonpoint-source urban runoff. These sites included the Reedy River (S-018), Sugar Creek (C9790000), Fairforest Creek (B-021), Crowders Creek (CW-023 and C8660000), and the Catawba River (C-016 and C-041). The highest concentrations of ammonia nitrogen and nitrite-plusnitrate nitrogen were approximately an order of magnitude higher in the Broad and Catawba subunits than those in the Edisto and Cooper subunits, because the majority of the urban sites are located in the upper part of the study area.

Depending on concurrent $\mathrm{pH}$ and temperature values, high concentrations of ammonia nitrogen (up to $15 \mathrm{mg} / \mathrm{L}$ ) may have exceeded chronic aquatic-life criteria at several sites. Nitrite-plus-nitrate nitrogen concentrations ranged up to $17 \mathrm{mg} / \mathrm{L}$, exceeding the USEPA MCL of $10 \mathrm{mg} / \mathrm{L}$. Total Kjeldahl nitrogen concentrations ranged from 0.09 to $22 \mathrm{mg} / \mathrm{L}$ and were elevated at one non-urban site, the Pocotaligo River (MD007), possibly resulting from high levels of organic nitrogen draining from wetlands. Total phosphorus ranged from below detection to $11 \mathrm{mg} / \mathrm{L}$. Many samples had concentrations that exceeded the USEPA guidance levels of $0.1 \mathrm{mg} / \mathrm{L}$ for streams not entering impoundments.

Temporal trends at most sites were either absent or showed decreases in most nutrient concentrations. Of the 90 sites analyzed for trends only 3 sites showed increasing trends for ammonia nitrogen, 7 sites for nitrite-plus-nitrate nitrogen, 3 sites for total Kjeldahl nitrogen, and 2 sites for total phosphorus. Three adjoining basins in North Carolina, Buffalo Creek (A8600000), First Broad River (A6400000), and Second Broad River (A4400000) were the only sites that showed increasing trends for more than a single constituent. All 3 sites showed increasing trends for total Kjeldahl nitrogen, the Second Broad River and Buffalo Creek showed increasing trends for nitrite-plus-nitrate nitrogen, and the First Broad River and Buffalo Creek showed increasing trends for total phosphorus. These 
trends may result from increased urbanization and/or agricultural land use in the upper Broad River watershed.

Nonpoint-source contributions also were estimated for the study area. Average annual deposition of ammonia and nitrate nitrogen in urban and nonurban areas were calculated, and nitrogen and phosphorus loads from manure and fertilizer were estimated for the entire study area and for selected stations in the Broad and Saluda River drainage basins. The atmospheric contribution of nitrogen species was greater than the agricultural contribution. The sum of atmospheric loads of ammonia nitrogen and nitrate nitrogen to the total study area was estimated to be $184 \mathrm{ktons} / \mathrm{yr}$, while agricultural loads of total nitrogen were estimated to be $79 \mathrm{ktons} / \mathrm{yr}$. Agricultural loads of total phosphorus to the total study area were estimated to be $29 \mathrm{ktons} / \mathrm{yr}$.

Sufficient data were available at 7 stations in the study area to estimate loads of ammonia nitrogen, nitrite-plus-nitrate nitrogen, total Kjeldahl nitrogen, and total phosphorus. Four stations were located in the Broad River drainage basin and 3 in the Saluda River drainage basin. Monthly and annual median loads were calculated for each constituent at each site.

Changes between upstream and downstream loads in the Broad and Saluda River drainage areas were strongly influenced by the differences in the impoundments located between the sites. Downstream loads of ammonia nitrogen were higher than the sum of upstream loads, with the exception of the monthly median loads for February, March, and April in the Broad River drainage basin. Nitrite-plus-nitrate nitrogen loads were seasonal, with downstream loads lower than the sum of the upstream loads during the summer months. The downstream summer decrease is probably a result of increased assimilation of nitrogen by aquatic vegetation during this time and is much more pronounced in the Saluda River drainage basin than the Broad River drainage basin because of the longer residence time of the water in Lake Greenwood. Total Kjeldahl nitrogen loads were generally higher at the downstream sites than the sum of the upstream sites and showed a similar seasonal pattern to the nitriteplus-nitrate nitrogen loads. Total phosphorus loads were consistently lower at the downstream stations indicating that Parr Reservoir and Lake Greenwood are significant sinks for phosphorus. Because of its larger size and residence time, Lake Greenwood reduced median annual total phosphorus loads between upstream and downstream sites by 24 to 80 percent whereas Parr Reservoir reduced the load by 15 to 47 percent.

Nitrate concentrations in ground water were compared using data from 3 sampling networks. The networks included agriculturally influenced wells (Clemson network), ambient water-quality monitoring wells (SCDHEC network), and a compilation of existing data on all types of wells (USGS network). The agriculturally infiuenced wells of the Clemson network had consistently higher median nitrate concentrations than either the SCDHEC or USGS networks. The 90thpercentile concentration of nitrate in the Clemson network wells equalled the USEPA MCL for drinking water of $10 \mathrm{mg} / \mathrm{L}$ in the Floridan aquifer. A comparison of the USGS network to the SCDHEC network is probably inappropriate because of differences in network design and size.

\section{REFERENCES}

Bucklin, C.F., 1994, South Carolina ambient ground-water quality monitoring network, South Carolina Department of Health and Environmental Control: GroundWater Protection Division, $39 \mathrm{p}$.

Chatterjee, S., and McLeish, D.L., 1986, Fitting linear regression models to censored data by least squares and maximum likelihood methods: Communications in Statistics--Theory and Methods, v. 15, no. 11, p. 32273243.

Cohn, T.A., Delong, L.L., Gilroy, E.J., Hirsch, R.M., and Wells, D.K., 1989, Estimating constituent loads: Water Resources Research, v. 25, no. 5, p. 937-942.

Cooney, T.W., Jones, K.H., Drewes, P.A., Gissendanner, J.W., and Church, B.W., 1995, Water Resources Data-South Carolina Water Year 1994, Volume 1: U.S. Geological Survey Water-Data Report SC-94-1, 520 p.

1996, Water Resources Data--South Carolina Water Year 1995, Volume 1: U.S. Geological Survey WaterData Report SC-95-1, 622 p.

Crawford, C.G., 1991, Estimation of suspended-sediment rating curves and mean suspended-sediment loads: Journal of Hydrology, v. 129, p. 331-348.

-1996 , Estimating mean constituent loads in rivers by the rating-curve and flow-duration, rating-curve methods: Bloomington, Indiana, Indiana University, Ph.D. dissertation, $245 \mathrm{p}$.

Daniel, C.C., III, White, R.K., and Stone, P.A., eds., 1992, Ground water in the Piedmont--Proceedings: Conference on ground water in the Piedmont of the eastern United States: Clemson, S.C., Clemson University, $693 \mathrm{p}$. 
Dempster, A.P., Laird, N.M., and Rubin, D.B., 1977, Maximum likelihood from incomplete data via the EM algorithm: Journal of the Royal Statistical Society, Series B, v. 39 , no. 1, p. 1-22.

Flegal, A.R., and Coale, K.H., 1989, Methods for determination of inorganic substances in water and fluvial sediments: U.S. Geological Survey Techniques of WaterResources Investigations, book 5, chap. A1, 3d edition, $545 \mathrm{p}$.

Giese, G.L., Mason, R. R., and Strickland, A.G., 1986, National Water Summary - Ground-water quality: North Carolina: U.S. Geological Survey Water Supply Paper 2325, p. 393-400.

Helsel, D.R., and Hirsh, R.M., 1992, Statistical Methods in Water Resources: New York, Elsevier, 522 p.

Hem, J.D., 1985, Study and interpretation of the chemical characteristics of natural water: U.S. Geological Survey Water-Supply Paper 2254, 263 p.

Hirsch, R.M., Slack, J.R., and Smith, R.A., 1982, Techniques of trend analysis for monthly water-quality data: Water Resources Research, v. 18, no. 1, p. 107-121.

Hughes, W.B., 1994, National Water-Quality Assessment Program--The Santee Basin and Coastal Drainage, N.C. and S.C.: U.S. Geological Survey Fact Sheet 94-010, $2 \mathrm{p}$.

Kendall, M.G., 1975, Rank correlation methods (4th ed.): London, Charles Griffin.

Klaassen, C.D., Amdur, M.O., and Doull, John, 1986, Toxicology: The basic science of poisons: New York, Macmillan Publishing Co., 974 p.

Mitchell, W.B., Guptill, S.C., Anderson, K.E., Fegras, R.G., and Hallam, C.A., 1977, GIRAS-A geographic information and analysis system for handling land-use and land-cover data: U.S. Geological Survey Professional Paper 1059, $16 \mathrm{p}$.

Mueller, D.K., Hamilton, P.A., Helsel, D.R., Hitt, K.J., and Ruddy, B.C., 1995, Nutrients in ground water and surface water of the United States - An analysis of data through 1992: U.S. Geological Survey WaterResources Investigations Report 95-4031, 74 p.

Nacht, S.J., 1983, Monitoring sampling protocol considerations, Ground Water Monitoring Review, p. 23-29.

National Atmospheric Deposition Program (NRSP-3)/ National Trends Network, 1995: Fort Collins, NADP/ NTN Coordination Office, Natural Resource Ecology Laboratory, Colorado State University.

Newcome, Roy, 1989, Ground-water resources of South Carolina's Coastal Plain -- 1988: S.C. Water Resources Commission Report Number 167.

North Carolina Agricultural Statistics Service, 1993, 1993 North Carolina agricultural statistics: Raleigh, $80 \mathrm{p}$.

Patterson, G.G., 1983, Effect of the proposed Cooper River rediversion on sedimentation in Charleston Harbor, South Carolina, U.S. Geological Survey WaterResources Investigation Report 83-4198, 65 p.
Patterson, G.G., and Padgett, G.G., 1984, Quality of water from bedrock aquifers in the South Carolina Piedmont: U.S. Geological Survey Water-Resources Investigations Report 84-4028, 24 p.

Puckett, L.J., 1995, Identifying the major sources of nutrient water pollution: Environmental Science \& Technology, v. 29 , no. 9 , p. $408-414$.

Sisterson, D.L., 1990, NAPAP Report 8, Acidic deposition: State of science and technology, Appendix A: Washington, D.C., National Acid Precipitation Assessment Program.

South Carolina Agricultural Statistics Service, 1995, South Carolina Agricultural Statistics Crops, Livestock, and Poultry 1993-1995: Columbia, 77 p.

South Carolina Department of Health and Environmental Control, 1981, A nutrient assessment of Lake Greenwood, South Carolina: Columbia, South Carolina Department of Health and Environmental Control, $81 \mathrm{p}$. 1995, Phosphorus in the Reedy River: Columbia, South Carolina Department of Health and Environmental Control, 5 p.

South Carolina Water Resources Commission, 1983, South Carolina state water assessment: South Carolina Water Resources Commission Report no. 140, 367 p.

1991, Inventory of Lakes in South Carolina: South Carolina Water Resources Commission Report no. 171, $320 \mathrm{p}$.

Speiran, G.K., Oldham, R.W., Duncan, D.A., and Knox, R.L., 1986, National Water Summary--Ground-water quality: South Carolina: U.S. Geological Survey WaterSupply Paper 2325, p. 449-456.

U.S. Environmental Protection Agency, 1986, Quality criteria for water 1986: Washington D.C., U.S. Environmental Protection Agency report EPA 570/9-82/002. 1990, County-level fertilizer sales data: U.S. Environmental Protection Agency Office of Policy, Planning, and Evaluation (PM-221).

-1991, National Secondary Drinking Water Standards, U.S. Environmental Protection Agency report EPA 570/9-91-019F, $32 \mathrm{p}$.

1993, Nitrogen control manual: Office of Research and Development, Office of Water, EPA/625/R-93/010, $311 \mathrm{p}$.

U.S. Geological Survey, 1992, U.S. Geodata: Land use and land cover data: U.S. Geological Survey Earth Science Information Center, $4 \mathrm{p}$.

Westman, W.E., 1985, Ecology, impact assessment, and environmental planning: New York, John Wiley \& Sons, Inc., $532 \mathrm{p}$.

Wolynetz, M.S., 1979, Algorithm 139--Maximum likelihood estimation in a linear model with confined and censored data: Applied Statistics, v. 28, p. 195-206. 